\title{
Flexwerk in Nederland
}

Citation for published version (APA):

Cörvers, F., \& van Thor, J. A. F. (2010). Flexwerk in Nederland. ROA. ROA Technical Reports No. 002 https://doi.org/10.26481/umarot.2010002

Document status and date:

Published: 01/01/2010

DOI:

10.26481/umarot.2010002

Document Version:

Publisher's PDF, also known as Version of record

\section{Please check the document version of this publication:}

- A submitted manuscript is the version of the article upon submission and before peer-review. There can be important differences between the submitted version and the official published version of record.

People interested in the research are advised to contact the author for the final version of the publication, or visit the DOI to the publisher's website.

- The final author version and the galley proof are versions of the publication after peer review.

- The final published version features the final layout of the paper including the volume, issue and page numbers.

Link to publication

\footnotetext{
General rights rights.

- You may freely distribute the URL identifying the publication in the public portal. please follow below link for the End User Agreement:

www.umlib.nl/taverne-license

Take down policy

If you believe that this document breaches copyright please contact us at:

repository@maastrichtuniversity.nl

providing details and we will investigate your claim.
}

Copyright and moral rights for the publications made accessible in the public portal are retained by the authors and/or other copyright owners and it is a condition of accessing publications that users recognise and abide by the legal requirements associated with these

- Users may download and print one copy of any publication from the public portal for the purpose of private study or research.

- You may not further distribute the material or use it for any profit-making activity or commercial gain

If the publication is distributed under the terms of Article $25 \mathrm{fa}$ of the Dutch Copyright Act, indicated by the "Taverne" license above, 


\title{
Flexwerk in Nederland
}

\author{
F. Cörvers \\ J. van Thor
}

\section{ROA Technical Report}

ROA-TR-2010/2

Research Centre for Education and the Labour Market Maastricht University

P.O. Box 616,6200 MD Maastricht, The Netherlands

$\mathrm{T}+31433883647 \mathrm{~F}+31433884914$

secretary-roa-sbe@maastrichtuniversity.n www.roa.nl 


\title{
Flexwerk in Nederland
}

\author{
F. Cörvers \\ J. van Thor
}

ROA-TR-2010/2

Maart 2010

Research Centre for Education and the Labour Market Maastricht University

P.O. Box 616, 6200 MD Maastricht, The Netherlands

$\mathrm{T}+31433883647 \mathrm{~F}+31433884914$

secretary-roa-sbe@maastrichtuniversity.nl www.roa.nl 


\section{Voorwoord}

In dit werkdocument wordt verslag gedaan van een onderzoek naar flexibele arbeid in Nederland. Het onderzoek heeft plaatsgevonden in het kader van het Project OnderwijsArbeidsmarkt. Een gedeelte van dit werkdocument is in geactualiseerde vorm terug te vinden in hoofdstuk 4 van De arbeidsmarkt naar opleiding en beroep tot 2014 (ROA, 2009).

Het Project Onderwijs-Arbeidsmarkt (POA) wordt gefinancierd door het Ministerie van Onderwijs, Cultuur en Wetenschap (OCW), het Uitvoeringsinstituut Werknemersverzekeringen (UWV), het UWV Werkbedrijf, het Ministerie van Landbouw, Natuur en Voedselkwaliteit (LNV), de samenwerkende kenniscentra voor beroepsonderwijs en bedrijfsleven COLO, Randstad Nederland en de Raad voor Werk en Inkomen (RWI). 


\section{Inleiding}

Er wordt vaak beweerd dat de flexibilisering van arbeid steeds belangrijker wordt. ${ }^{1}$ Bedrijven zouden in toenemende mate geconfronteerd worden met onzekerheid en schommelingen in de afzet, snelle technologische veranderingen en daaruit voortvloeiende organisatorische veranderingen met meer autonomie op de werkvloer en meer maatwerk voor de klant, wereldwijde concurrentie en bedrijfsverplaatsingen als gevolg van outsourcing en offshoring, etc. Ook onder werknemers lijkt er meer belangstelling te zijn voor flexibilisering van de arbeid. Het gaat daarbij om zaken als deeltijdwerk, werktijden, thuiswerken, kinderopvangarrangementen bij werkgevers, levensloopregelingen, etc. Door de toegenomen mondigheid en emancipatie in samenhang met de stijging van het opleidingsniveau zouden werknemers steeds meer verantwoordelijkheden in hun baan willen hebben en telkens weer zoeken naar nieuwe uitdagingen. Door de sterke toename van de arbeidsparticipatie onder vrouwen en de sterk veranderde huishoudsamenstelling (i.e. meer eenpersoonshuishoudens en eenoudergezinnen) heeft het traditionele kostwinnersmodel aan belang ingeboet. Dus ook werknemers zouden meer dan voorheen flexibiliteit van werkgevers verwachten wat betreft hoeveel, wanneer en waar men werkt, en flexibiliteit ten aanzien van de inhoud van het werk en de loopbaanperspectieven.

Externe (of numerieke) flexibiliteit is voor bedrijven van belang om schommelingen in de vraag naar goederen en diensten te kunnen opvangen. ${ }^{2}$ Door een beroep te doen op de externe arbeidsmarkt kunnen bedrijven in hun behoefte aan personeel voorzien. Werkenden met een flexibel arbeidscontract kunnen immers worden opgeroepen in drukke perioden, en kunnen weer 'naar huis' als ze niet meer nodig zijn. Een implicatie hiervan is dat numerieke flexibiliteit leidt tot een grotere arbeidsmobiliteit en een grotere conjunctuurgevoeligheid van de werkgelegenheid en de economie (De Beer, 2004). Daarnaast kunnen werknemers met een flexibele baan minder profiteren van loonprofielen die oplopen met het aantal dienstjaren, dan werknemers met een vaste aanstelling (vgl. Picchio, 2006). Het gaat hierbij niet alleen om uitzendkrachten, maar ook om werknemers met een kortdurig dienstverband, oproepkrachten en detacheringconstructies. ${ }^{3}$

Interne (of functionele) flexibiliteit zorgt ervoor dat de werkenden op de interne arbeidsmarkt van bedrijven flexibel inzetbaar zijn. De productie wordt daarbij zodanig georganiseerd dat werknemers op verschillende posities binnen de organisatie werkzaam kunnen zijn. Dit in tegenstelling tot de productie in een traditionele tayloristische organisatie, waarin sprake is van een gedetailleerde arbeidsverdeling en functiespecialisatie (SCP, 2004). Als werknemers wat betreft hun inzetbaarheid minder afhankelijk zijn van een specifiek productieproces in een bedrijf, kunnen zowel technologische en organisatorische veranderingen als conjunctuurschommelingen beter worden opgevangen door de eigen werknemers.

1. Zie voor een overzicht Goudswaard (2003) en SCP (2004).

2. Een deel van deze inleiding is ontleend aan Cörvers en Montizaan (2006).

3. Detachering wordt echter door Goudswaard (2003) beschouwd als externe kwalitatieve flexibiliteit. Zie hieronder.

2 
In Goudswaard (2003) wordt ingegaan op een met het bovenstaande overeenkomende veel gebruikte indeling van flexibele arbeid volgens het zogenaamde flexibiliteitskwadrant. Flexibele arbeid kan worden ingedeeld in functionele flexibiliteit (interne kwalitatieve flexibele arbeid), flexibele contracten (externe kwantitatieve flexibele arbeid) en flexibele werktijden (interne kwantitatieve flexibele arbeid). Zij onderscheidt bovendien een vierde vorm van flexibiliteit, te weten externe kwalitatieve flexibiliteit. Hiermee wordt op detachering en uitbesteding gedoeld. ${ }^{4}$

Dus werkgevers die op zoek zijn naar flexibele arbeid hebben twee mogelijkheden om hieraan invulling te geven: door interne flexibiliteit of door externe flexibiliteit (zie ook De Haan et al., 1994). Onder interne flexibiliteit wordt verstaan dat werkgevers hun werknemers de mogelijkheid bieden om onder wisselende arbeidstijden te werken, om hen overwerk te laten doen, of door werknemers intern over te plaatsen en/of op te leiden. Externe flexibiliteit wil daarentegen zeggen dat de werkgever tijdelijk extra arbeidskrachten inschakelt. De focus in het voorliggende document ligt op externe flexibiliteit, ook wel contractflexibiliteit genoemd (Knegt et al., 2007). Flexibele arbeidskrachten die het betreft worden flexwerkers genoemd.

Het CBS hanteert de volgende definitie voor flexwerkers: "Werknemers met een flexibel dienstverband (flexwerkers) zijn werknemers zonder vast dienstverband. Zij hebben een arbeidscontract van beperkte duur en/of een arbeidscontract zonder een vast overeengekomen aantal uren in dienst". ${ }^{5}$ Hierbij onderscheidt het CBS de volgende verschijningsvormen van flexwerkers: uitzendkrachten, oproep- of invalkrachten, en personen met een tijdelijk dienstverband. Knegt et al. (2007) onderscheiden achtereenvolgens: werknemers met een tijdelijk contract, zelfstandigen zonder personeel, freelancers en opdrachtnemers, inval- of oproepkrachten, uitzendkrachten en thuiswerkers. Pot, Koene en Paauwe (2001) rekenen de volgende groepen tot flexibele arbeidskrachten: uitzendkrachten, personen met een tijdelijk contract (minder dan een jaar), oproepkrachten en zelfstandigen die zich laten inhuren.

In de literatuur worden echter nog meer verschillende vormen van flexibele arbeid benoemd. Vaak worden er verschillende definities gehanteerd voor flexibele arbeid, waardoor het niet eenvoudig is om aan te geven welke contracten precies als flexibel aangeduid kunnen worden (Zijl, 2006). Volgens Zijl bestaat er in het algemeen overeenstemming dat personen met een contract voor bepaalde tijd en uitzendkrachten tot de flexibele arbeidskrachten gerekend kunnen worden. Over de vraag of arbeidsovereenkomsten op freelance-basis, oproepkrachten, deeltijdwerkers en zelfstandigen ook tot de flexibele arbeidskrachten behoren, bestaat minder overeenstemming. Volgens Zijl (2006) is de gangbare definitie van flexibele arbeid ontleend aan Polivka en Nardone (1989). Deze luidt als volgt: "Elke vorm van arbeid waarbij iemand geen expliciet of impliciet contract heeft voor een lange termijn, of waarbij het minimum aantal werkuren kan variëren op een niet-systematische wijze".

\footnotetext{
4. Op detachering wordt in de volgende paragraaf teruggekomen. Zie het proefschrift van Goudswaard (2003) voor een uitgebreide verhandeling over de verschillende typologieën van flexibiliteit.

5. http://www.cbs.nl/nl-NL/menu/methoden/toelichtingen/alfabet/f/flexibel-dienstverband.htm
} 
Het spreekt voor zich dat de vele verschillende definities van flexwerk het vergelijken van de cijfers tussen de verschillende onderzoeken bemoeilijkt. Het is dan ook belangrijk om eerst goed te kijken naar de verschillende verschijningsvormen van flexwerk die in een onderzoek onderscheiden worden, alvorens de conclusies van het onderzoek met die in andere onderzoeken te vergelijken.

In het licht van de eerder genoemde toename van de flexibilisering van arbeid kan men verwachten dat ook het deel van de beroepsbevolking dat een flexibele baan heeft sterk is toegenomen. In het voorliggende onderzoek zal dit worden nagegaan. Het doel van de studie is tweeledig. Ten eerste wordt getracht een beter zicht te krijgen op de functie die flexibele arbeidsvormen op de arbeidsmarkt vervullen. In de publicaties van het ROA wordt er doorgaans vanuit gegaan dat de meeste mensen een vaste baan prefereren boven een flexibele baan. De tijdelijkheid van een baan wordt doorgaans gezien als een minder aantrekkelijk baankenmerk, waarmee veel werknemers noodgedwongen genoegen moeten nemen als de arbeidsmarktsituatie verslechtert. De vraag die nu gesteld wordt is wat de voor- en nadelen van een flexibele arbeidsrelatie zijn, voor zowel de werkgever als de werknemer. Op basis van een inventarisatie van de economische literatuur zullen de verschijningsvormen en functies van flexibele arbeid worden onderzocht. Ten tweede zal er informatie worden gegeven over de vele verschijningsvormen waarin flexibele arbeid zich manifesteert binnen sectoren, beroepen en opleidingen, en over de tijd. De gegevensbronnen die worden gebruikt zijn de Enquête Beroepsbevolking (EBB), het Sociaal Statistisch Bestand (SSB), Statline van het CBS, en de schoolverlatersenquêtes van het ROA.

In hoofdstuk 2 wordt ingegaan op de verschillende verschijningsvormen van flexibele arbeid. Vervolgens wordt in hoofdstuk 3 ingegaan op het belang van een aantal van deze verschijningsvormen op de Nederlandse arbeidsmarkt ten opzichte van andere landen. Hoofdstuk 4 geeft een overzicht van de overwegingen die bij werknemers en werkgevers volgens de economische literatuur een rol spelen bij het aangaan van een flexibele arbeidsrelatie. In hoofdstuk 5 wordt ingegaan op de Nederlandse wetgeving die een rol speelt bij het verklaren van de omvang van flexibele ten opzichte van vaste arbeidsrelaties. In hoofdstuk 6 wordt een overzicht gegeven van de kenmerken van werknemers met een flexibele arbeidsrelatie. In hoofdstuk 7 wordt ingegaan op de ontwikkeling van flexibele arbeid op macroniveau en in de verschillende sectoren, opleidingen en beroepen. Tot slot volgen in hoofdstuk 8 de conclusies.

\section{Verschijningsvormen van flexibele arbeid}

Flexibele contracten kunnen gerangschikt worden naar de mate van flexibiliteit die zij de werkgever, opdrachtgever en werknemer bieden. Bepaalde contractvormen zijn zeer flexibel te noemen, terwijl andere contractvormen meer naar een vast contract neigen. Volgens De Graaf-Zijl (2005) verschilt een contract voor bepaalde tijd in veel opzichten niet al te veel van een contract voor onbepaalde tijd. Zo komt een werknemer met een contract voor bepaalde tijd ook rechtstreeks in dienst bij de werkgever waar hij het contract bij getekend heeft. Het 
belangrijkste verschil is volgens haar dat werkgevers na afloop van een contract voor bepaalde tijd geen ontslagvergoeding verschuldigd zijn. Een dergelijk contract loopt namelijk automatisch af op een vooraf overeengekomen einddatum. Doorgaans wordt deze contractvorm gebruikt om te bekijken of de werknemer naar behoren functioneert of om tijdelijke veranderingen in de vraag op te kunnen vangen. Naast verschillen in ontslagkosten is de tijdelijke aard van het contract daarom een belangrijke motivatie van werkgevers om de voorkeur te geven aan contracten voor bepaalde tijd boven contracten voor onbepaalde tijd. Als het contract voor bepaalde tijd bedoeld is om te bekijken hoe een werknemer functioneert, is het achterliggende doel van de werkgever vaak om het contract bij gebleken geschiktheid om te zetten in een contract voor onbepaalde tijd.

De contracten van uitzendkrachten zijn een stuk flexibeler van aard dan contracten voor onbepaalde en bepaalde tijd. Uitzendkrachten komen in dienst bij een uitzendbureau, maar staan onder supervisie van de organisatie waar ze naar uitgezonden worden. Een werkgever kan voor een dergelijke vorm van flexibele arbeid kiezen als hij op korte termijn iemand nodig heeft. Bijkomende voordelen voor de werkgever hebben volgens De Graaf-Zijl (2005) betrekking op 'replacement', dat wil zeggen dat de werkgever geen opzegtermijn in acht hoeft te nemen, evenals dat hij geen ontslagkosten hoeft te betalen. Nadelen voor de werkgever kunnen zijn dat uitzendkrachten geen opzegtermijn hebben, dat ze meestal voor een beperkte tijd beschikbaar zijn en dat het uitzendbureau de uitzendkracht selecteert. ${ }^{6}$

Contracten op detacheerbasis komen op veel punten overeen met uitzendcontracten. Zo ook qua arbeidsverhouding tussen detacheerbureau, gedetacheerde en organisatie die gebruik maakt van de diensten van de detacheerbare persoon. De gedetacheerde staat onder contract bij het detacheerbureau. Echter in tegenstelling tot een uitzendkracht, legt de gedetacheerde in eerste instantie verantwoording af aan het detacheerbureau. Mensen met een detacheercontract zijn op korte termijn beschikbaar, er hoeft daarnaast geen ontslagvergoeding aan hen uitgekeerd te worden en de opdrachtgever heeft geen opzegtermijn waar hij rekening mee dient te houden. Aan de andere kant is de opdrachtgever voor de selectie van de gedetacheerde afhankelijk van het detacheerbureau en is een detacheercontract doorgaans van korte duur. Een werkgever zal volgens De Graaf-Zijl (2005) normaal gesproken voor deze flexibele contractvorm kiezen als hij voor korte tijd iemand nodig heeft met specifieke kennis die op dat moment in de organisatie ontbreekt. Vaak gaat het bij deze contractvorm om hooggeschoolde personen of personen met veel ervaring.

Ook freelancers kunnen door een werkgever ingezet worden als er specifiek werk van tijdelijke aard is. Voordelen van het inzetten van zelfstandigen voor de werkgever zijn dat hij geen ontslagvergoeding hoeft te betalen en dat hij bovendien geen opzegtermijn in acht hoeft te nemen. Het inzetten van freelancers is volgens De Graaf-Zijl (2005) het meest

6. Dit kan overigens ook een voordeel zijn. Het uitzendbureau heeft waarschijnlijk vaak meer ervaring met de 'screening' van arbeidskrachten, die ook kan plaatsvinden in combinatie met het aanbieden van algemene training (zie bijv. Autor, 2001). 
effectief in dynamische omgevingen, terwijl deze contractvorm het best tot zijn recht komt als er relatief weinig ervaring is vereist om de klus te kunnen klaren.

De meest vergaande vorm van flexibele arbeidscontracten zijn oproepkrachten, aangezien bij deze contractvorm de flexibiliteit in gewerkte uren doorgaans het grootste is. De werkgever bepaalt zelf voor hoeveel uur hij werk heeft voor de oproepkracht. Oproepkrachten komen ook rechtstreeks in dienst bij de organisatie waarvoor ze werken. Hun contract kan echter zowel tijdelijk als ook voor onbepaalde tijd zijn. Volgens De GraafZijl (2005) ontvangen oproepkrachten een hogere beloning ter compensatie van de hoge mate van onzekerheid inzake de te werken uren. Oproepkrachten zijn voornamelijk terug te vinden in sectoren met veel wisselingen in de vraag. Het gaat daarbij tevens vaak om laaggeschoold werk waarvoor weinig ervaring nodig is.

\section{Nederlandse situatie in internationale context}

Berkhout en Van Leeuwen (2004) hebben onderzoek gedaan naar de beschikbaarheid van internationale gegevens over flexibele arbeid. Zij onderscheiden hierbij vier vormen van flexibele arbeid, te weten zelfstandigen, parttimers, contracten voor bepaalde tijd (zowel fulltime als parttime), en tot slot uitzendwerk. Voor deze vier verschijningsvormen zal Nederland worden vergeleken met andere landen.

\section{Zelfstandigen}

Figuur 3.1 laat de ontwikkeling van het percentage zelfstandigen zien tussen 1974 en 2000 . In Italië zijn relatief de meeste zelfstandigen te vinden gedurende de hele periode. Ook in Spanje en Portugal zijn relatief veel zelfstandigen actief, al neemt dit percentage aan het einde van de reeks af. Deze landen steken boven de andere landen uit op het gebied van het aandeel zelfstandigen. In de andere landen bedraagt het aandeel zelfstandigen in deze periode tussen de 5 en 15\%. In Nederland schommelt het aandeel zelfstandigen volgens deze cijfers over de hele periode tussen de 7 en $10 \%$. 
Figuur 3.1

Zelfstandigen in OECD-landen, percentage van de werkgelegenheid, 1974-2000

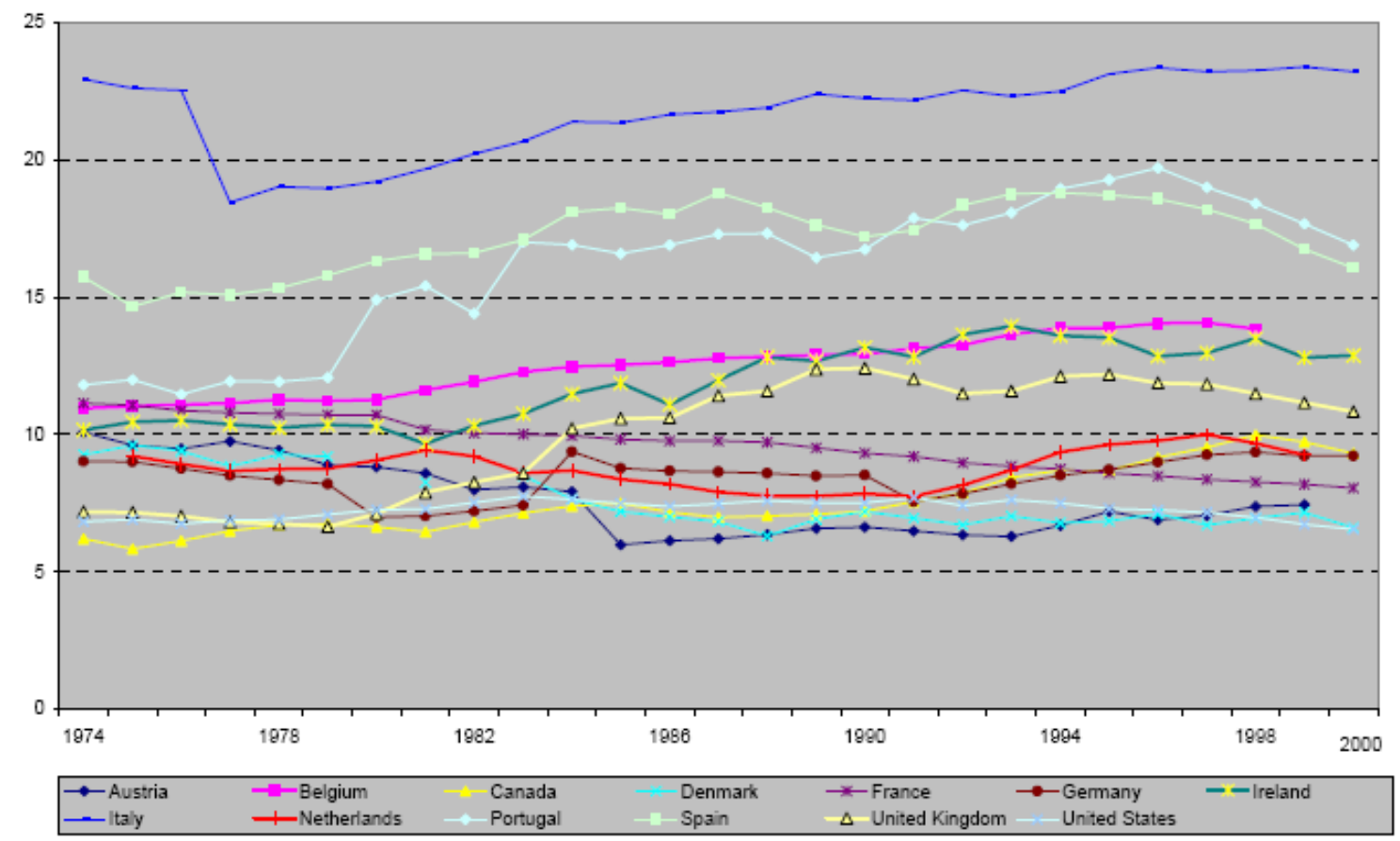

Bron: OECD Labour Market Statistics 2001 (2002)

* In deze cijfers zijn de zelfstandigen in de landbouwsector niet meegenomen. Deze sector geeft doorgaans een vertekend beeld van de werkelijkheid in alle andere sectoren, omdat er in de landbouw een veel groter dan gemiddeld aandeel zelfstandigen is (Berkhout en Van Leeuwen, 2004).

\section{Deeltijdwerk}

In tabel 3.1 wordt het percentage deeltijdwerk weergeven voor Nederland in vergelijking met een aantal andere Europese landen. Hieruit blijkt dat Nederland koploper is in het percentage werkenden met een deeltijdbaan.

\section{Tabel 3.1}

Deeltijdwerk volgens Eurostat, percentage van de werkgelegenheid, 1983, 1990-2002

\begin{tabular}{lrrrrrrrrrrrrrr}
\hline Land & 1983 & 1990 & 1991 & 1992 & 1993 & 1994 & 1995 & 1996 & 1997 & 1998 & 1999 & 2000 & 2001 & 2002 \\
\hline België & 6,8 & 9,7 & 10,4 & 10,8 & 11,4 & 11,4 & 12,3 & 12,5 & 13,1 & 14,4 & 18,4 & 20,7 & 18,2 & 19,4 \\
Denemarken & 21,3 & 21,3 & 21,2 & 20,5 & 21,3 & 20 & 20,4 & 19,8 & 21,0 & 21,0 & 19,4 & 21,7 & 20,1 & 20,6 \\
Duitsland & 12,2 & 14,8 & 13,7 & 14 & 14,7 & 15,4 & 15,9 & 16,2 & 17,1 & 17,9 & 18,6 & 19,4 & 20,3 & 20,8 \\
EU & & 13,1 & 13,1 & 13,8 & 13,2 & 15 & 15,6 & 16 & 16,6 & 17,0 & 17,3 & 18,0 & 18,0 & 18,2 \\
Frankrijk & 9,4 & 11,8 & 11,9 & 12,5 & 13,6 & 14,7 & 15,4 & 15,8 & 16,7 & 17,1 & 17,0 & 16,9 & 16,4 & 16,2 \\
lerland & 3,4 & 4,5 & 4,6 & 4,5 & 7,0 & 8,4 & 9,4 & 8,4 & 8,6 & 14,1 & 13,2 & 16,6 & 16,6 & 16,5 \\
Italië & 4,1 & 4,3 & 5,0 & 5,4 & 5,0 & 5,6 & 5,9 & 6,1 & 6,5 & 7,0 & 7,5 & 8,8 & 9,1 & 8,6 \\
Nederland & 20,1 & 30,9 & 31,9 & 34 & 34,5 & 35,9 & 36,8 & 37,6 & 37,5 & 38,3 & 39,0 & 41,2 & 42,2 & 43,8 \\
Oostenrijk & & & & & & & 12 & 13,2 & 13,3 & 14,3 & 15,1 & 17 & 17,2 & 18,9 \\
Portugal & & 3,8 & 4,6 & 5,3 & 5,2 & 5,5 & 4,7 & 5,9 & 6,9 & 8,0 & 8,1 & 10,7 & 11,1 & 11,3 \\
Spanje & & 4,6 & 4,2 & 5,4 & 6,1 & 6,4 & 6,9 & 7,5 & 7,8 & 7,6 & 7,9 & 8,2 & 8,1 & 8,0 \\
UK & 18,0 & 20,7 & 21,2 & 22,0 & 22,4 & 22,9 & 23,0 & 23,7 & 24,1 & 23,9 & 23,8 & 24,9 & 24,8 & 25,0 \\
Zwitserland & & & & & & & & 25,8 & 27,3 & 27,6 & 28,5 & 30,5 & 31,8 & 31,7 \\
\hline Bron: Eurostat Labour Force Surveys & & & & & & & & & & & &
\end{tabular}


De OECD corrigeert deze cijfers aangezien de verschillende landen andere definities hanteren. De OECD gaat bij de gegevensverwerking van deeltijdwerk uit van 30 uren of minder per week. In figuur 3.2 worden de door de OECD gecorrigeerde cijfers weergegeven. Ook volgens de OECD steekt Nederland er wat betreft deeltijdwerk ver bovenuit in Europa. Op ruime afstand wordt Nederland gevolgd door Zwitserland en Groot-Brittannië. De ZuidEuropese landen maken aanzienlijk minder gebruik van werken in deeltijd; Spanje en Portugal scoren het laagst, gevolgd door Italië.

Figuur 3.2

Deeltijdwerk volgens OECD, percentage van de werkgelegenheid, 1990, 1999-2002

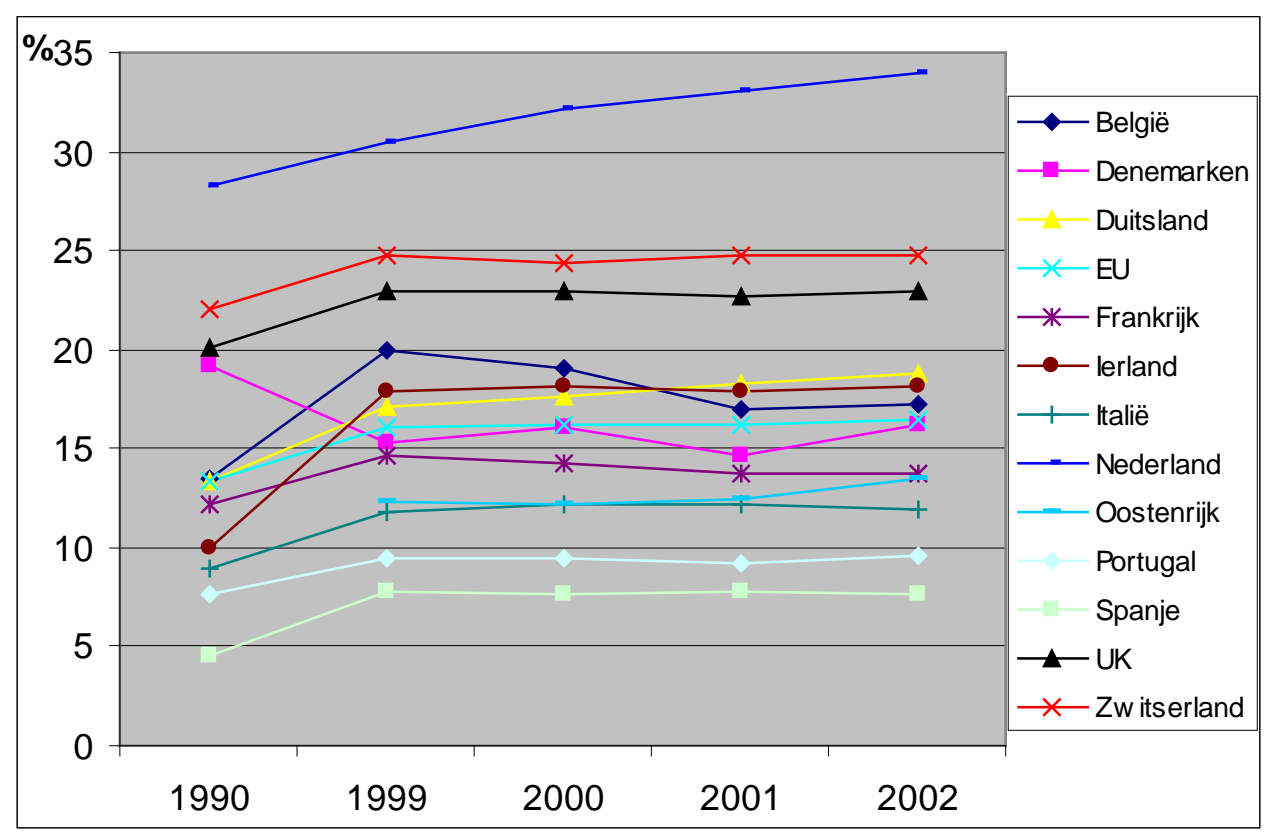

Bron: OECD Employment Outlook (2003)

\section{Tijdelijk en uitzendwerk}

Berkhout en Van Leeuwen (2004) laten zien hoe het in Nederland gesteld is met de omvang van het tijdelijk werk ten opzichte van andere landen. Personen met een tijdelijk contract kunnen in hun studie zowel uitzendkrachten zijn als mensen met een contract voor bepaalde tijd. In figuur 3.3 wordt het percentage tijdelijk werk in Nederland weergegeven ten opzichte van een aantal andere Europese landen. Op basis vban de gegeven definitie springt Spanje er in één oogopslag bovenuit met een aandeel tijdelijke arbeidskrachten van boven de $30 \%$. Ook in Portugal krijgen mensen relatief vaak een tijdelijk contract. Nederland laat een stijging zien vanaf 1990, al stagneert de groei sinds 2000 . In de overige landen heeft tussen de 5 en 15\% een tijdelijk contract. Verder wordt duidelijk dat er voor veel landen geen duidelijke trend is tussen 1985 (of 1990) en 2002. 
Figuur 3.3

Tijdelijk werk, percentage van de werkgelegenheid, 1985, 1990, 1995, 2000-2002

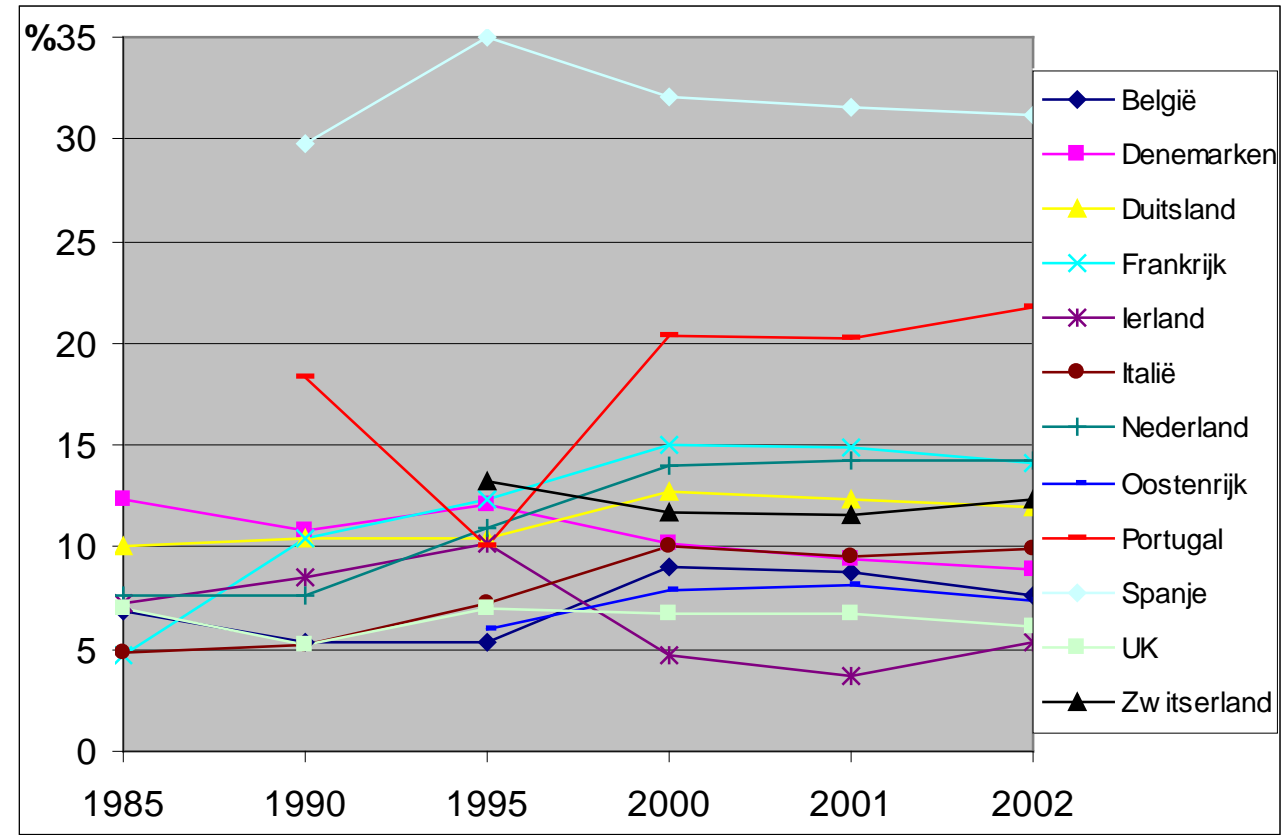

Bron: OECD Labour Market Statistics 2001 (2002), Eurostat Labour Force Surveys

In figuur 3.4 wordt ingegaan op de beweegredenen die mensen in verschillende landen hebben ten aanzien van het aangaan van een tijdelijk contract. Uit de figuur blijkt dat er grote verschillen tussen landen kunnen bestaan. Zo gaan mensen in Spanje voornamelijk een tijdelijk contract aan omdat ze geen vaste baan kunnen vinden. Van alle werkenden in Spanje geeft $25 \%$ aan dat dit de belangrijkste reden is voor het hebben van een dergelijk contract, wat overeenkomt met $76 \%$ van alle mensen met een tijdelijk contract (Berkhout en Van Leeuwen, 2004). In Nederland (en Portugal) daarentegen zijn er relatief veel mensen die vrijwillig voor een tijdelijk contract gekozen hebben, met als reden dat zij niet op zoek zijn naar een vaste baan. 
Figuur 3.4

Beweegredenen voor het aangaan van een tijdelijk contract, 1999

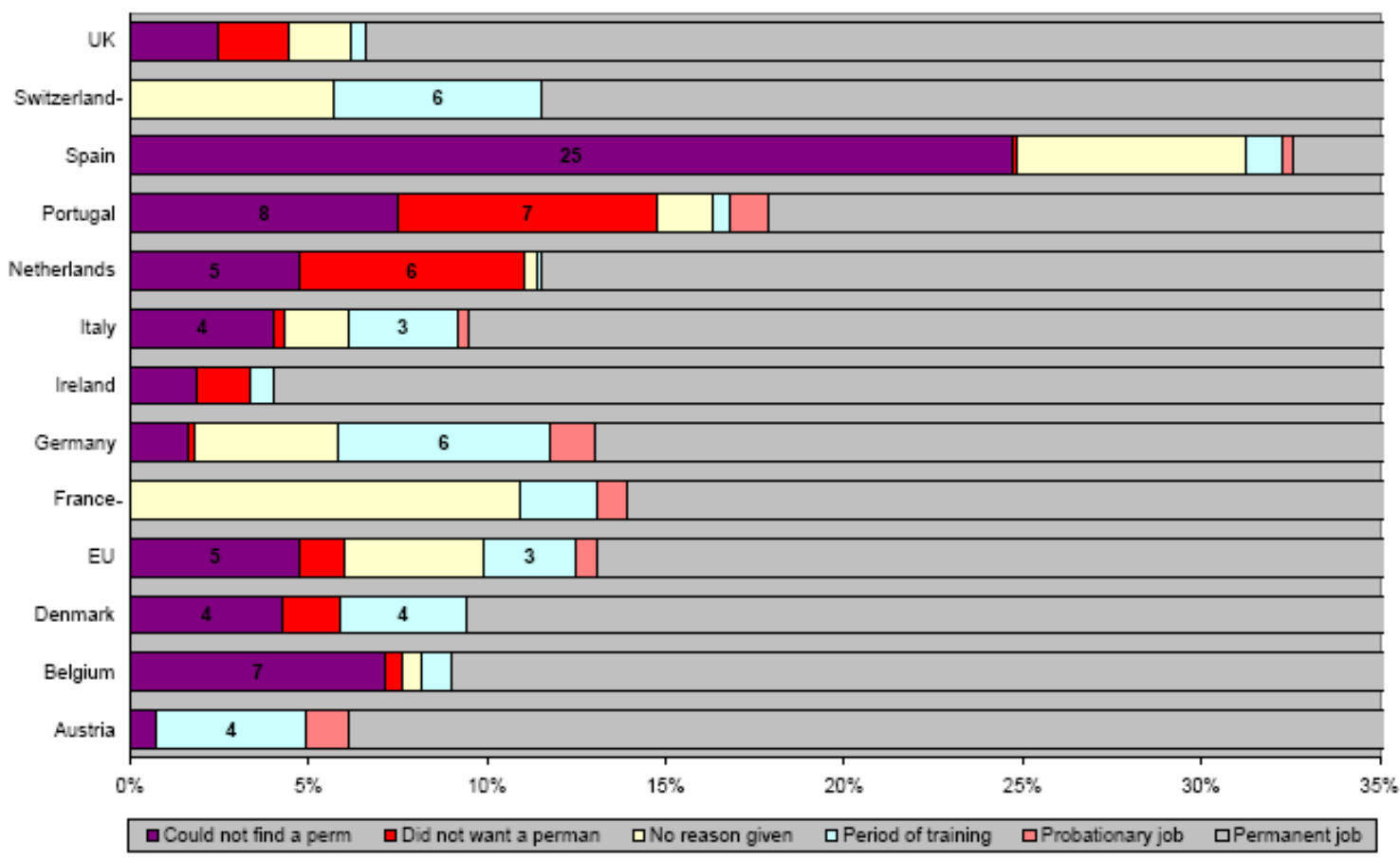

Source: Eurostat LFS (2000)

Op basis van gegevens van het Eurociett ${ }^{7}$ kan worden nagegaan hoe het belang van het uitzendwerk op de Nederlandse arbeidsmarkt zich verhoudt tot dat in andere landen. In figuur 3.5 is het aantal uitzendkrachten in voltijdsequivalenten als percentage van de werkzame beroepsbevolking in het jaar 2006 weergegeven voor 19 verschillende landen. Eurociett concludeert dat de penetratiegraad van uitzendkrachten (aantal voltijdsequivalenten van de totale werkzame beroepsbevolking) in Europa gemiddeld $1,8 \%$ is. Uit de figuur blijkt dat Nederland met 2,5\% hierin achter Groot-Brittannië (4,5\%) een tweede plaats inneemt. Andere Europese landen met een relatief groot aantal uitzendkrachten zijn Frankrijk (2,4\%) en België $(2,1 \%)$.

7. Europese Confederation of Private Employment Agencies. Zie: http://www.euro-ciett.org/index.php?id=134 
Figuur 3.5

Uitzendwerk in voltijdsequivalenten als percentage van de werkzame beroepsbevolking, 2006

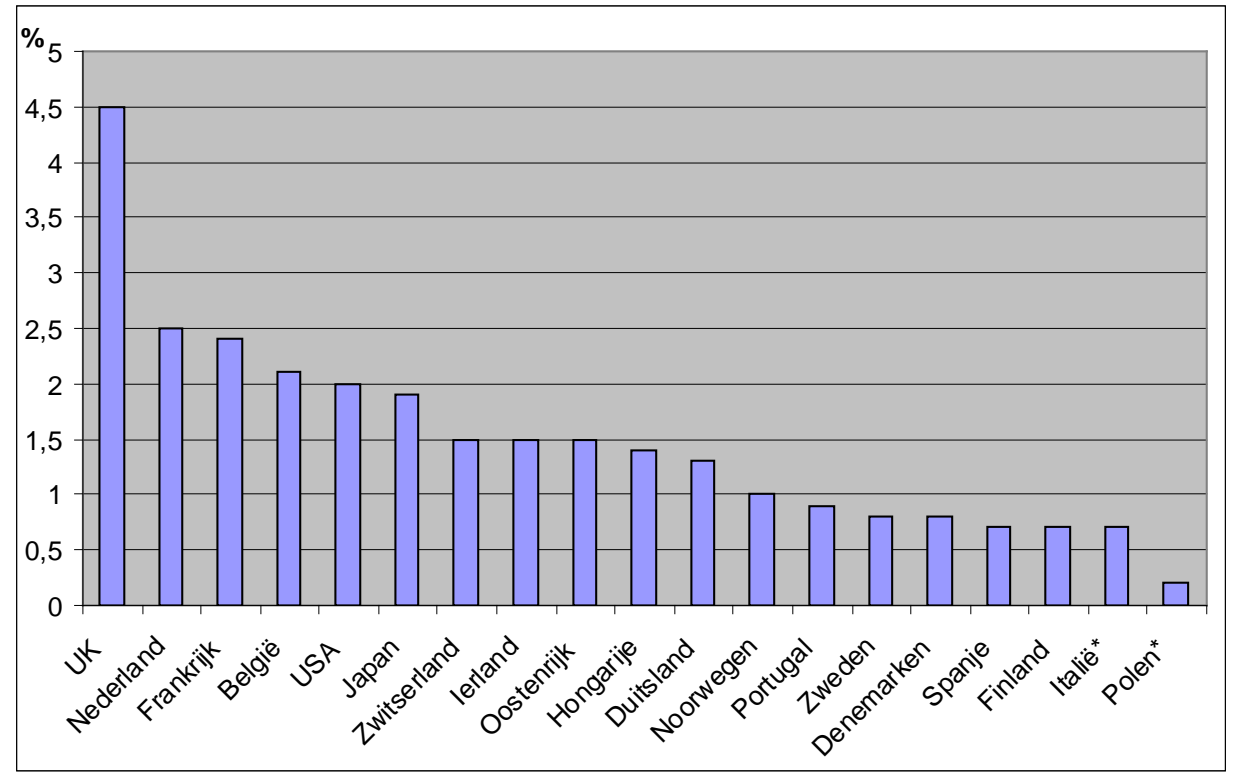

Bron: Eurociett

* Percentages geschat

Figuur 3.6 geeft het aantal uitzendbureaus in 1996 en 2006 weer voor dezelfde landen (Hongarije en Finland uitgezonderd). Hieruit blijkt dat er een toename is te zien in het aantal uitzendbureaus in de verschillende landen (uitgezonderd de VS, Zwitserland en Spanje). In Nederland waren er in 1996 nog 400 uitzendbureaus, in 2006 was dit aantal gestegen naar 2.100 .

Figuur 3.6

Aantal uitzendbureaus in 1996 en 2006

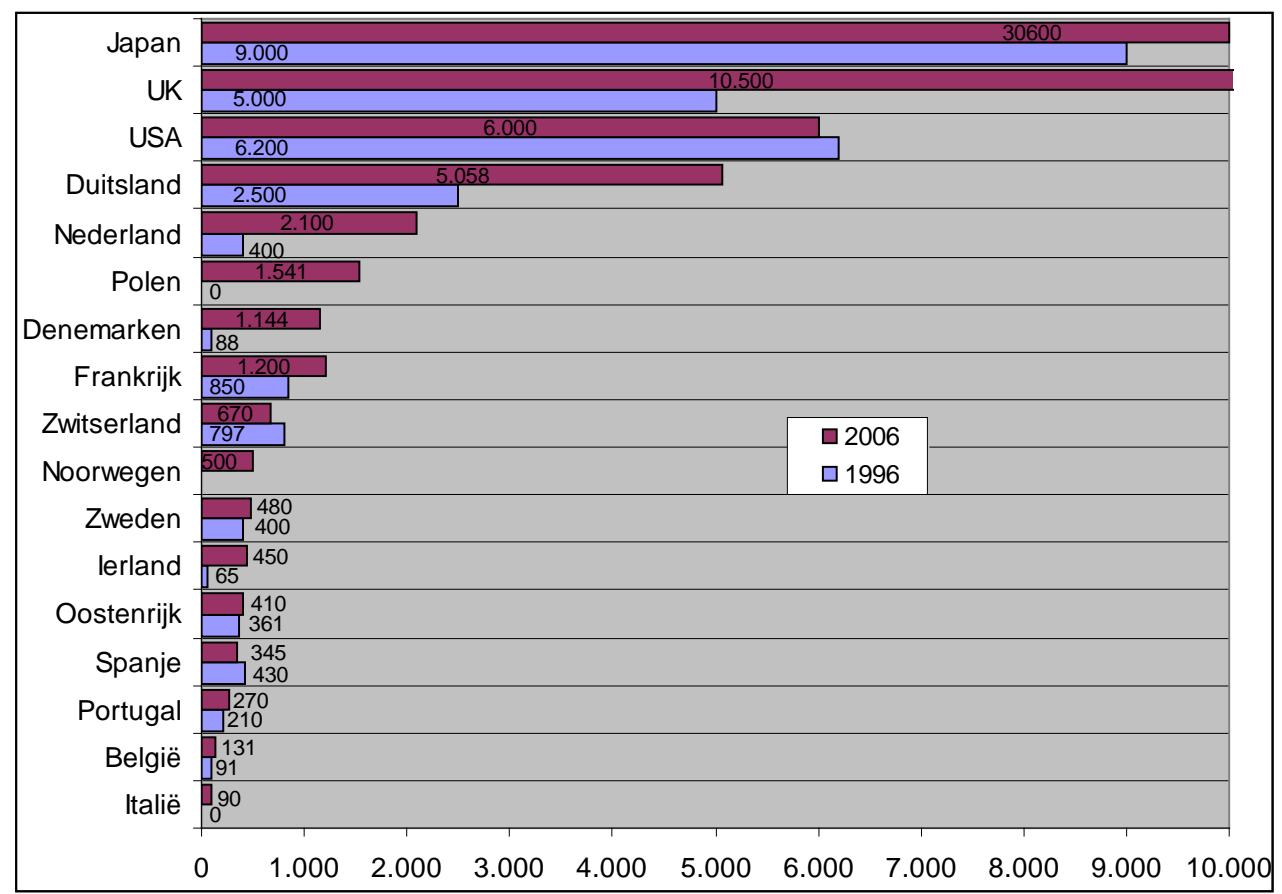

Bron: Eurociett 
Tabel 3.2

Overzicht van cijfers over uitzendkrachten in verschillende EU-landen

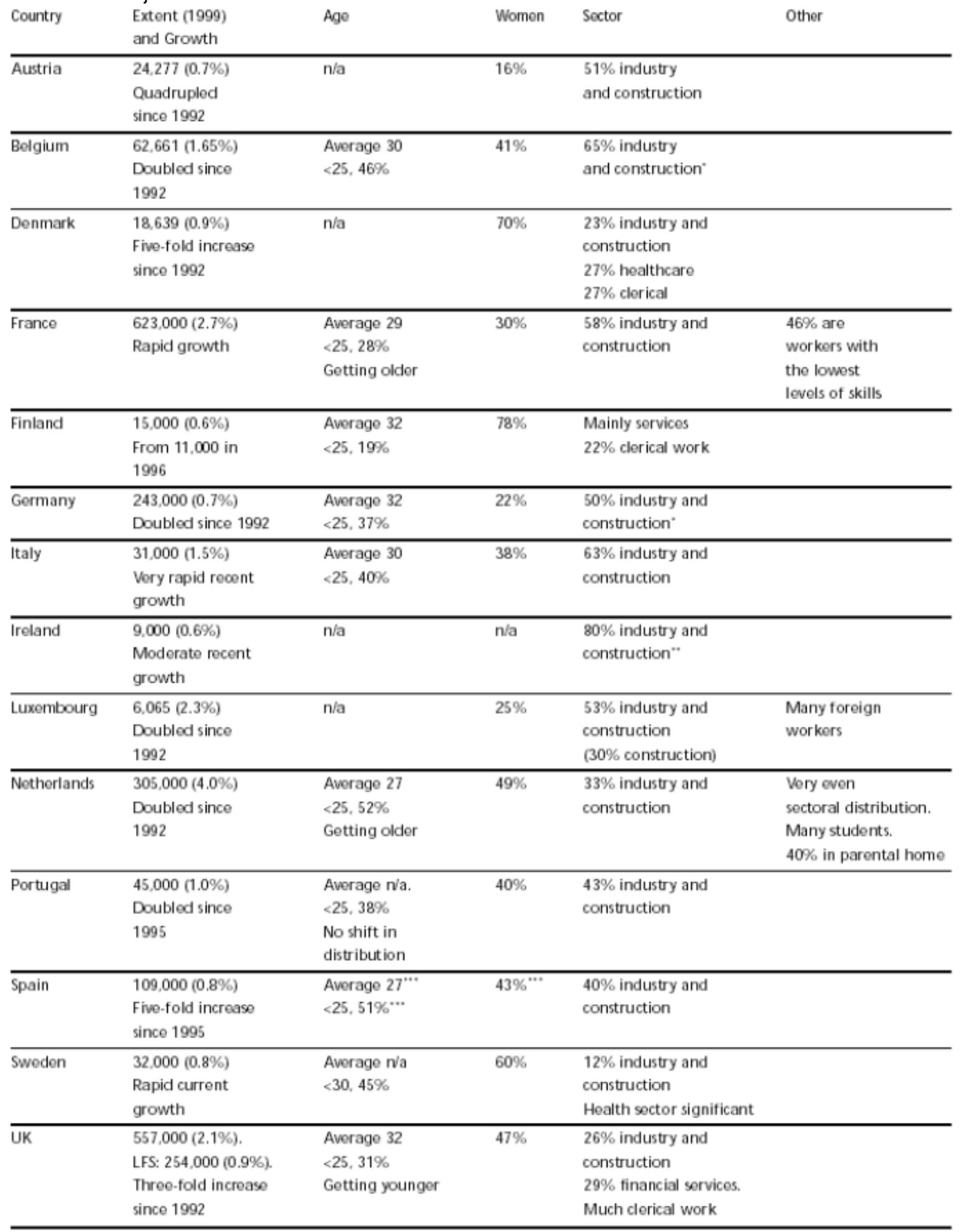

* Agency work is prohibited in construction

** This figure is rather uncertain

**** These figures are probably too high but are the only ones available.

Source: Storrie (2002). 
Tot slot wordt in tabel 3.2 een overzicht gegeven van onder andere de omvang en groei van het uitzendwerk in verschillende Europese landen op basis van Storrie (2002). In de tabel wordt ingegaan op de kenmerken van de uitzendkrachten en de sectoren waarin zij voornamelijk werkzaam zijn. Het blijkt dat uitzendkrachten in de verschillende landen vooral in de industrie werkzaam zijn. De typische uitzendkracht is een man, laagopgeleid en jonger dan 25 jaar (zie ook Berkhout en Van Leeuwen, 2004). Vooral in Nederland zijn de uitzendkrachten jong, en relatief veel van deze jongeren hebben hun opleiding niet afgemaakt. Volgens Storrie (2002) is het aandeel uitzendwerk als percentage van de werkgelegenheid in de meeste landen sterk gestegen sinds het begin van de jaren negentig. In Nederland is het uitzendwerk verdubbeld sinds 1992 en bestaat rond 2000 4\% van de totale werkgelegenheid uit uitzendwerk. ${ }^{8}$

\section{Theoretische overwegingen bij een flexibele arbeidsrelatie}

\section{Functies van flexibel werk voor de werkgever}

Werkgevers kunnen verschillende beweegredenen hebben voor het aangaan van een flexibel dienstverband. De Graaf-Zijl (2005) ziet het zo laag mogelijk houden van de kosten voor het aanpassen van het personeelsbestand als belangrijkste beweegreden voor de werkgever om flexibele arbeidscontracten aan te gaan. De keuze van de werkgever om voor een tijdelijk contract te kiezen blijkt nauw samen te hangen met de hogere mate van ontslagbescherming die kleeft aan vaste werknemers (Zijl, 2006). Te denken valt hier aan ontslag bij vraagschommelingen of bij slecht functioneren. Aan vaste krachten zou de werkgever in dergelijke gevallen hoge kosten moeten betalen.

Houseman (2001) stelt dat het opvangen van schommelingen in de vraag naar producten en diensten, en het opvangen van tijdelijke absenties van het eigen personeel voor werkgevers de meest voorkomende argumenten zijn voor het inschakelen van flexibele arbeidskrachten. Volgens deze redenering bieden uitzendbureaus arbeidskrachten aan op de zogenaamde 'spot market', waardoor ondernemingen hun personele problemen snel kunnen oplossen. Een andere verklaring voor het inschakelen van flexibele arbeidskrachten is dat flexibele contracten door werkgevers gebruikt kunnen worden als 'screening instrument' voor een eventueel hieruit voortvloeiend vast contract. Wanneer blijkt dat de flexwerker voldoet aan de eisen van de werkgever, kan deze besluiten om het contract van deze flexwerker om te zetten in een vast contract. Wanneer dit niet het geval is, zijn er geen kosten verbonden om van de werknemer af te komen. Autor (2004) stelt dat de tweede verklaring zelfs veel belangrijker is dan de eerste in het geval van uitzendwerk. Door training aan te bieden aan uitzendkrachten en ze te testen op hun kwaliteiten, verzamelen uitzendbureaus waardevolle informatie omtrent de kwaliteiten en motivatie van de uitzendkrachten. Hierdoor zijn ze beter in staat om een goede 'match' te maken tussen de uitzendkracht en de vacature. Door het beter bedienen van hun klanten genereren ze een hogere toegevoegde waarde, waardoor de trainingskosten kunnen worden terugverdiend.

8. Het verschil met figuur 3.5 is te verklaren doordat de cijfers betrekking hebben op verschillende definities. 
Daarnaast kan een werkgever volgens Houseman (2001) kiezen voor flexibele arbeidskrachten met het oog op bezuinigingen op salaris, ${ }^{9}$ opleidingsmogelijkheden of andere aanvullende secundaire arbeidsvoorwaarden. Andere mogelijke redenen die Houseman onderscheidt bij het kiezen voor flexibele arbeidskrachten zijn: een gebrek aan capabele vaste arbeidskrachten, het tijdelijk invullen van een functie ter overbrugging tot een vaste werknemer aangenomen wordt en het inhuren van expertise die niet in de onderneming aanwezig is tijdens projecten.

\section{Functies van flexibel werk voor werknemers}

Ook voor personen die op dit moment werkloos zijn kan flexibele arbeid uitkomst bieden. Voor werklozen kan flexibele arbeid uitkomst bieden om de arbeidsmarkt (opnieuw) te betreden (Zijl, 2006). Dit beperkt de werkloosheidsduur. Voor deze groep kan flexibele arbeid verder dienen als springplank naar een vast dienstverband ('stepping stone' hypothese, zie Zijl et al., 2004). Deze groep krijgt namelijk de mogelijkheid om op basis van een flexibel contract toch aan het arbeidsproces deel te nemen. Volgens Zijl kunnen zij hierdoor werkervaring opdoen en human capital verwerven of eventueel uitbreiden, waardoor zij aantrekkelijker worden voor werkgevers. Dit hangt nauw samen met het vergroten van iemands employability (Ecorys-NEI, 2002).

Als andere mogelijke voordelen noemt Zijl (2006) dat een persoon met een tijdelijk contract zijn bestaande informele netwerk kan uitbreiden (wat indirect weer tot een aantrekkelijkere baan kan leiden) en dat deze daarnaast de kans krijgt om zich binnen dat bedrijf te bewijzen. Aangezien de werkgever minder risico loopt bij het aangaan van een flexibel contract ten opzichte van een vast contract, kan deze bij twijfels besluiten om de arbeidskracht allereerst een flexibel contract aan te bieden. Als na verloop van tijd blijkt dat de flexibele arbeidskracht naar behoren presteert, kan de werkgever hem alsnog in vaste dienst nemen. Dit komt overeen met het eerder genoemde screeningsinstrument voor de werkgever. Een laatste mogelijk voordeel dat Zijl (2006) voor flexkrachten ziet, is dat werknemers met een tijdelijk contract blijk kunnen geven van hun motivatie. Zodoende kunnen zij een signaal afgeven aan een werkgever met betrekking tot hun drijfveren en capaciteiten.

Houseman (2001) voegt hier nog twee voordelen van flexwerk voor tijdelijke arbeidskrachten aan toe. Allereerst kan aan arbeidskrachten met speciale additionele kwaliteiten een tijdelijk contract aangeboden worden. Deze tijdelijke arbeidskrachten kunnen hun specifieke kennis en ervaring op tijdelijke basis inbrengen. Zij zouden normaliter echter nooit een vast contract gekregen hebben, omdat ze maar tijdelijk door de werkgever gebruikt kunnen worden. Flexibele arbeidscontracten maken het voor deze personen toch mogelijk om aan de slag te gaan. Bovendien kan het volgens Houseman (2001) de wens van de arbeidskracht zelf zijn om parttime of slechts tijdelijk bij de werkgever aan de slag te gaan. Hier valt onder meer te denken aan het kiezen voor een goede 'work-life balance' of de tijdelijke overbrugging naar een andere (vaste) baan.

9. Zie hieronder voor een verdere beschouwing over de lonen van flexibele arbeidskrachten. 
In Ecorys-NEl (2002) worden naast de eerder genoemde motieven nog enkele andere motieven genoemd die iemand kan hebben bij de keuze voor uitzendwerk. Deze kunnen echter ook gelden voor andere verschijningsvormen van flexibele arbeid. Zo kan een werknemer uitzendwerk zelf bijvoorbeeld ook gebruiken als screeningsinstrument voor mogelijke interessante werkgevers. Ook kunnen arbeidskrachten voor uitzendwerk kiezen als zij voor afwisseling in hun werkzaamheden willen zorgen. Deze contractvorm kan namelijk voor meer afwisseling zorgen dan het geval is bij een vaste baan. Daarnaast worden in Ecorys-NEI (2002) inkomensgerelateerde motieven van flexibele arbeid genoemd. In de eerste plaats verschaft flexibele arbeid de arbeidskracht natuurlijk inkomen dat hij niet, of in mindere mate, gehad zou hebben als hij niet zou werken. Tevens kan flexibele arbeid dienen als aanvullend inkomen op een andere baan of tijdens studie. Een voorbeeld van deze laatste groep is een student c.q. vakantiewerker.

Veel recente empirische studies (waaronder Zijl et al., 2004) vinden gunstige effecten van uitzendwerk op de werkloosheidsduur en de daarop volgende baanzekerheid van werkenden. Uit Amerikaans onderzoek op basis van experimenten en controlegroepen blijkt echter dat de korte termijn voordelen van uitzendwerk niet opwegen tegen de nadelen op lange termijn wat betreft loonontwikkeling en baanzekerheid (zie bijv. Autor en Houseman, 2005).

\section{Loonvorming bij flexibele arbeidskrachten}

De meeste werknemers prefereren een vaste baan boven een flexibele. Voor werkgevers geldt in beginsel echter het omgekeerde: zij willen graag werknemers snel en zonder kosten kunnen ontslaan als de productie daalt. Volgens de theorie van de compenserende loonverschillen (zie bijv. Rosen, 1974), zouden werknemers alleen een flexibele baan accepteren als zij in ruil daarvoor een hoger loon krijgen dan werknemers met een vaste baan. Uit empirisch onderzoek blijkt echter dat de beloning van flexibele arbeidskrachten vrijwel altijd lager is dan voor vaste krachten met dezelfde achtergrondkenmerken voor één en dezelfde baan (zie bijv. EU, 2003). Ook blijkt dat deze 'wage penalties' voor flexwerkers in elk EU-land bestaan. Deze 'wage penalties' variëren van $5 \%$ minder loon in Frankrijk, Duitsland, Oostenrijk, België en Oostenrijk tot meer dan 15\% minder loon in Nederland.

In Picchio (2006) wordt een overzicht gegeven van de redenen waarom uitzendkrachten minder verdienen dan vaste krachten. Allereerst verwijst Picchio naar Rebitzer en Taylor (1991). Deze vinden dat de optimale strategie voor werkgevers, in een duale arbeidsmarkt met volledige substitutie tussen vaste en flexibele arbeidskrachten, waar werkgevers moeilijkheden ondervinden bij het monitoren van werknemers en die tevens gekenmerkt wordt door vraagschommelingen, bestaat uit het in dienst nemen van zowel vaste als flexibele arbeidskrachten, waarbij laatst genoemde groep een lagere beloning ontvangt. Flexibele arbeidskrachten worden hierbij ingezet voor het opvangen van korte termijn schommelingen in de vraag. In het evenwicht is er daarbij sprake van een overschot van vaste krachten en lagere beloning van flexibele arbeidskrachten. 
Daarnaast kan het lagere loon van flexibele arbeidskrachten volgens Bentolila en Dolado (1994) verklaard worden vanuit de zogenaamde insider-outsider theorie. Zij betogen dat wanneer personen met een vast dienstverband (insiders) de vakbonden domineren, dit betekent dat de insiders meer macht krijgen en zo het loonniveau omhoog kunnen stuwen door middel van deze vakbondswerking. Dit omdat de onderhandelingspositie van de insiders verbeterd wordt door de aanwezigheid van outsiders (flexibele arbeidskrachten).

Ook vanuit het oogpunt van de human capital theorie kan verklaard worden waarom flexwerkers normaliter lagere lonen ontvangen dan vaste medewerkers. Deze theorie beweert dat zowel de werkgever alsook flexwerkers zelf minder incentives hebben om te investeren in bedrijfsspecifiek human capital, omdat de arbeidsrelatie slechts van korte duur is. Wanneer tijdelijke contracten gezien worden als screeningsinstrument voor de werkgever, kan een tijdelijk contract bij goed functioneren worden omgezet in een vast contract.

Het 'shirking wage efficiency' framewerk van Güell (2000) laat een negatief verband zien tussen het hebben van een tijdelijk contract en de hoogte van het loon, omdat de werkgever het loon in mindere mate gebruikt als incentive om productief te blijven voor personen met een tijdelijk contract. Deze groep blijft al productief door het uitzicht op verlening van het tijdelijke contract of uitzicht op een permanent contract. Personen met een vast contract hebben deze zekerheid al en worden meer gemotiveerd door een hogere beloning.

Loh (1994) wijst in dit verband ten slotte nog op de kans op zelfselectie van werknemers die banen met een proeftijd accepteren. Degenen die een baan met proeftijd accepteren, blijken efficiënter te werken en tevens minder vaak te stoppen dan personen die kiezen voor een baan zonder proeftijd. Loh suggereert dat dit komt doordat personen die er geen vertrouwen in hebben dat zij door de proeftijd komen, doorgaans ook niet zullen solliciteren op een vacature met proeftijd. Gemotiveerde en bekwame personen kiezen volgens Loh net wel voor banen met proeftijd, omdat tegenover dergelijke banen in het algemeen een hogere beloning staat.

Uit het onderzoek van Houseman, Kalleberg, en Erickcek (2003) komt echter naar voren dat de beloning voor uitzendkrachten, afhankelijk van de sector waarin ze werken en de functie die zij daarin vervullen, hoger of lager kan zijn dan die van vaste krachten. Dit onderzoek betreft een case studie gericht op ziekenhuizen en bedrijven uit de auto-industrie. Houseman et al. (2003) vinden dat wanneer een arbeidsmarkt gekenmerkt wordt door krapte (in dit geval in ziekenhuizen), werkgevers bij het invullen van hogere functies een hoger loon aan uitzendkrachten betalen dan aan personen in vaste dienst. Volgens Houseman et al. (2003) kan het inzetten van relatief duur uitzendpersoneel werkgevers zodoende helpen om loonopdrijving van bestaand personeel tegen te gaan. Indien er geen uitzendkrachten beschikbaar zouden zijn geweest, zou de beloning van vaste medewerkers stijgen als gevolg van de krapte op de arbeidsmarkt.

Ten tijde van een krappe arbeidsmarkt wordt in lagere beroepen gebruik gemaakt van uitzendkrachten, zodat de kosten voor personeel waarvan de arbeidsproductiviteit op voorhand moeilijker te voorspellen is zo laag mogelijk gehouden worden. Zo kan "risicovol" 
personeel ingeschakeld worden dat werkt voor lagere lonen en slechtere arbeidsvoorwaarden. Daarbij worden de kosten die te maken hebben met het verloop laag gehouden.

\section{Veranderde wetgeving in het flexwerk}

De aantrekkelijkheid van flexwerk ten opzichte van vaste dienstverbanden wordt onder andere bepaald door het ontslagrecht bij beide soorten arbeidsrelaties. Indien de ontslagkosten van flexwerkers ten opzichte van vaste arbeidskrachten dalen dan wordt het voor werkgevers aantrekkelijker om flexwerkers in te zetten. Volgens Autor (2003) is de toename van de ontslagbescherming in de Verenigde Staten verantwoordelijk voor de stijgende belangstelling onder werkgevers voor dienstverbanden via de 'temporary work agencies' (uitzendbureaus). Door de werkgelegenheidsgroei in uitzendwerk te vergelijken tussen staten in de VS die wel en staten die geen wetten invoerden om werknemers in vaste dienst te beschermen tegen ontslag, kon hij vaststellen wat de invloed is van de wetgeving op het arbeidsvolume in het uitzendwerk. Hij schat dat in het jaar nadat staten ontslagbescherming invoerden de werkgelegenheid in uitzendwerk met gemiddeld dertien procent extra toenam. Volgens hem is de invoering van de ontslagbescherming in de VS verantwoordelijk voor ongeveer twintig procent van de werkgelegenheidsgroei in het uitzendwerk tussen 1973 en 1995.

Autor (2004) merkt op dat in de meeste OECD-landen de ontslagbescherming van vaste werknemers juist is afgenomen. Deze verandering kan derhalve de grote toename van het uitzendwerk in de landen van de OECD (OECD, 2002) niet verklaren. Maar in veel OECDlanden, waaronder ook Europese landen, zijn de mogelijkheden voor uitzendwerk juist verruimd. Zo is het uitzendwerk in Italië pas sinds 1997 legaal. De zogenaamde 'deregulering van de uitzendsector' is waarschijnlijk een belangrijke oorzaak voor de sterke stijging van het uitzendwerk in Europese landen.

In Nederland is er in vergelijking met tien jaar geleden veel veranderd met betrekking tot de wet- en regelgeving voor het tijdelijk inzetten van arbeidskrachten. In de jaren vóór 1999 waren er enkele knelpunten bij de inzet van tijdelijke arbeidskrachten, welke de vraag naar nieuwe wetgeving creëerden. De arbeidswetgeving zou gewijzigd moeten worden op een viertal punten (Smits en Samadhan, 2002):

1. De mogelijkheden op het gebied van tijdelijke arbeidsovereenkomsten;

2. De wetgeving ten aanzien van arbeidsrelaties bij uitzendwerk;

3. De bepalingen op het gebied van loondoorbetaling, opzegging en proeftijd;

4. Het vergunningenstelsel voor de uitzendsector.

In december 1995 stuurde de minister van Sociale Zaken en Werkgelegenheid een adviesaanvraag aan de Stichting van de Arbeid. Na bekendmaking van het advies van de Stichting van de Arbeid in april 1996, besloot het kabinet om vrijwel alle adviespunten uit deze nota Flexibiliteit en Zekerheid over te nemen in de nieuwe wetgeving. Vrijwel tegelijkertijd kwamen de ABU, NBBU, START en de vakverenigingen binnen de 
uitzendbranche een convenant overeen. Hierin kondigden de betrokken partijen aan dat er een CAO voor de uitzendbranche afgesloten zou worden, waarin onder meer afspraken stonden ten aanzien van rechtspositie, pensioen en scholing voor uitzendkrachten. In hetzelfde convenant zijn de partijen overeengekomen dat er nog voor afloop van de eerste CAO-periode (1999-2003) een evaluatie zou komen om te bezien of de in de Flexwet gemaakte afspraken aangepast zouden moeten worden.

\section{WAADI}

Op 1 juli 1998 is de Wet allocatie arbeidskrachten door intermediairs (WAADI) van kracht gegaan. Deze wet schrijft regels voor bij de bemiddeling naar arbeid door intermediairs en is gerelateerd aan de eerdergenoemde nota Flexibiliteit en Zekerheid. De WAADI maakt onderscheid tussen arbeidsbemiddeling en het ter beschikking stellen van arbeid (NEI, 2003). In de WAADI staan enkele ingrijpende veranderingen, voornamelijk op het gebied van de ter beschikking stelling van arbeid. Zo werden na invoering van deze wet de vergunningsplicht en de daaraan gelieerde maximale uitzendtermijn voor het ter beschikking stellen van arbeid afgeschaft (Zijl et al., 2003).

\section{Wet Flexibiliteit en Zekerheid}

Per 1 januari 1999 is vervolgens de Wet Flexibiliteit en Zekerheid (de 'Flexwet') in werking getreden. In de nieuwe wetgeving diende een stabiele arbeidsverhouding voorop te staan. Het doel van deze wet was dan ook tweeledig (Knegt et al., 2007). Enerzijds beoogde deze de mogelijkheden om flexibele arbeidskrachten in te zetten te verruimen, waardoor het voor de werkgever aantrekkelijker werd om van de diensten van flexibele arbeidskrachten gebruik te maken. Anderzijds beoogde deze wet de rechtspositie van deze flexibele arbeidskrachten te verbeteren door hun meer rechten en zekerheden te bieden op het gebied van werk, inkomen en uitkering. De wet zou tot gevolg moeten hebben dat de economische prestaties van bedrijven verbeteren door de inzet van flexibele arbeidskrachten, de werkgelegenheid toeneemt, de arbeidsmarkt beter functioneert (meer mobiliteit, minder krapte), en het aantal WW-uitkeringen afneemt (NEI, 2003).

De Flexwet is een zogenaamde wijzigingswet. De arbeidswetgeving werd met de invoering van de Flexwet aangepast ten aanzien van het aangaan, ontstaan en beëindigen van arbeidscontracten (Van den Toren, Evers, Commissaris, 2002). De Flexwet bestaat uit een opsomming van wijzigingen in het Burgerlijk Wetboek (BW), het Buitengewoon Besluit Arbeidsverhoudingen 1945 en enkele andere wetten (Van den Toren, Evers, Commissaris, 2002). Het overgrote deel van de wijzigingen heeft betrekking op het Burgerlijk Wetboek (BW 7). Hierin staan de bepalingen aangaande de arbeidsovereenkomst (BW7:690 \& art. 691). Met de invoering van de Flexwet zijn aanpassingen in het BW aangebracht ten aanzien van de algemene bepalingen, beloning, gelijke behandeling, proeftijd, (beëindiging van) de arbeidsovereenkomst en ten slotte de uitzendovereenkomst (NEI, 2003). Door de invoering van de Flexwet is de uitzendovereenkomst dus onderdeel gaan uitmaken van het arbeidsrecht (Zijl et al., 2003). 
Collectieve arbeidsovereenkomsten (CAO's)

De Flexwet maakte het mogelijk om per sector afwijkende CAO-afspraken te maken aangaande duur van het uitzendbeding, duur en aantal contracten voor bepaalde tijd en de loondoorbetalingverplichting (Zijl et al., 2003). Dit wordt ook wel als driekwart-dwingend recht aangeduid. Op basis van het uitzendconvenant zijn er twee CAO's voor de uitzendbranche opgesteld: één voor leden van de Algemene Bond Uitzendondernemingen $(A B U)$ en één voor leden van de Nederlandse Bond van Bemiddelings- en Uitzendondernemingen (NBBU). De CAO die in 1999 van kracht werd, mocht dus enigszins van de bepalingen van de Flexwet afwijken. Dit had als voordeel dat veel flexibiliteit, die op grond van de Flexwet was ingeperkt, alsnog behouden kon blijven (Zijl et al., 2003). Deze flexibiliteit is gerealiseerd door het invoeren van het zogenoemde keten- of fasesysteem. De achterliggende gedachte van het fasesysteem is dat een uitzendkracht meer rechten opbouwt naarmate hij langer bij een uitzendbureau werkt. Hoe verder een uitzendkracht in het fasesysteem doordringt, hoe meer rechten hij dus verwerft en hoe vaster de relatie met het uitzendbureau wordt. ${ }^{10}$ Voor iedere afzonderlijke fase is vastgelegd: het type uitzendoverkomst, het uitzendbeding, de onderbrekingstermijn, de aanzegtermijnen en ten slotte zowel de minimale als ook de maximale duur van de overeenkomst.

\section{ABU-CAO 1999-2003}

De ABU-CAO 1999-2003 bestond uit een viertal fasen. De eerste fase van dit systeem behelsde 26 weken. Deze hoefden overigens niet aansluitend te zijn. Als de uitzendkracht niet werkte ontving hij in deze fase ook geen loon. Hierna volgde een periode van opnieuw 26 weken. In deze tweede fase kreeg de uitzendkracht recht op pensioensopbouw en een scholingsgesprek (Smits en Samadhan, 2002). Evenals in fase 1 ontving de uitzendkracht in deze fase alleen een beloning als hij daadwerkelijk uitzendwerk verricht had. Na fase 1 en 2 bij één en hetzelfde uitzendbureau doorlopen te hebben, had de uitzendkracht in fase 3 recht op een uitzendovereenkomst van ten minste 3 maanden. In totaal kreeg de uitzendkracht in fase 3 maximaal twee tijdelijke contracten van 3 maanden (bij één inlenende werkgever) of acht tijdelijke contracten (bij meerdere inlenende werkgevers) (Smits en Samadhan, 2002). Deze periode kon voor de uitzendkracht dus maximaal 8 tijdelijke arbeidscontracten van in totaal 24 maanden duren (Zijl et al., 2003). De uitzendkracht kreeg zijn loon in deze fase gewoon doorbetaald als er tijdelijk geen werk voor hem beschikbaar was (Mitlacher, 2006). Hierna kwam de uitzendkracht in fase 4 terecht en werd zijn contract omgezet in een contract voor onbepaalde tijd bij het uitzendbureau (Mitlacher, 2006). Indien een uitzendkracht de gehele periode bij één inlenende werkgever gewerkt had, kreeg hij op zijn vroegst na 18 maanden een vast dienstverband. Had hij echter bij verschillende inlenende werkgevers gewerkt, dan was dit punt pas na 36 maanden bereikt (Smits en Samadhan, 2002).

De ABU-CAO 1999-2003 was algemeen bindend verklaard, waardoor deze van invloed was op alle uitzendkrachten (Zijl et al., 2003). Uit de tussentijdse evaluaties van deze eerste ABU-CAO kwam naar voren dat de nieuwe CAO voor uitzendkrachten aangepast zou moeten worden op het gebied van rechtpositie en beloningsregeling. Deze aanpassingen

10. Zie Samenvatting CAO voor Uitzendkrachten 2004 - 2009, uitgegeven door ABU (2007). 
beoogden, met inachtneming van WAADI artikel 8, de transparantie en toepasbaarheid van het nieuwe beloningssysteem in deze nieuwe CAO voor uitzendkrachten te vergroten (STAR, 2004). Tevens moesten deze leiden tot meer duidelijkheid over wanneer uitzendkrachten een gelijke beloning dienen te ontvangen als vergelijkbare werknemers van de inlenende organisatie.

Volgens NEI (2003) is het inzetten van oproep- en uitzendkrachten minder aantrekkelijk geworden voor werkgevers door de introductie van de rechtsvermoedens arbeidsovereenkomst en gemiddelde arbeidsduur. Een andere beperking voor werkgevers is de uitsluiting in de arbeidsovereenkomst van de beperking van doorbetaling van loon als er geen werk voor de oproepkracht is. Bovendien is het inlenen van uitzendkrachten door de invoering van de flexwet duurder geworden voor werkgevers. Er kan zo een verschuiving optreden van oproep- en uitzendwerk naar tijdelijk werk. De bepalingen uit de Flexwet hebben zodoende geleid tot substitutie tussen verschillende vormen van flexibel werk.

ABU-CAO 2004-2009

Sinds april 2004 is de nieuwe ABU-CAO voor uitzendkrachten van kracht voor de periode 2004-2009 (ABU, 2007). Deze CAO bestaat in tegenstelling tot de eerste CAO uit een drietal fasen. Fase $A$ is hierin een samenvoeging van de fasen 1 en 2 uit de ABU-CAO 1999-2003. De uitzendkracht bevindt zich in fase $A$, tot het moment dat hij 78 weken voor hetzelfde uitzendbureau gewerkt heeft. Deze fase is dus verlengd van 52 naar 78 weken (Zijl e.a., 2003). Het is daarbij toegestaan om een onderbreking tot 26 weken te hebben, zonder dat dit van invloed is op de opbouw van het totale aantal weken. Fase B vervangt de derde fase van de eerste ABU-CAO en duurt maximaal twee jaar of acht tijdelijke contracten bij hetzelfde uitzendbureau. In deze periode is er een tijdelijke onderbreking toegestaan van maximaal 13 weken. Fase $\mathrm{C}$ vervangt de vierde fase uit de vorige CAO en levert een contract voor onbepaalde tijd op. Deze laatste fase gaat in op het moment dat iemand na voltooiing van fase B blijft werken, of als deze persoon binnen 13 weken na voltooiing van fase B opnieuw wordt uitgezonden door dezelfde uitzendorganisatie. Een consequentie van de nieuwe wet- en regelgeving is dat een deel van de reguliere werkgevers en uitzendwerkgevers een toename van de administratieve lasten ervaart.

\section{Kenmerken flexwerkers in Nederland}

In deze paragraaf wordt ingegaan op de achtergrondkenmerken van flexwerkers in Nederland, in het bijzonder op de uitzendkrachten. Torka (2003) stelt dat verschillende achtergrondkenmerken invloed hebben op het hebben van een flexibel contract. Uit haar onderzoek blijkt dat geslacht, leeftijd, opleiding en etniciteit de kans op flexibele arbeid beïnvloeden. Tot de flexibele arbeidskrachten worden in deze paragraaf gerekend de werknemers met een tijdelijk dienstverband (korter dan een jaar) en werknemers van wie de arbeidsduur gewoonlijk varieert tussen een minimum en een maximum aantal uren per week, onder wie de uitzendkrachten, en de oproep- en invalkrachten. 


\section{Achtergrondkenmerken flexwerkers}

Volgens Torka (2003) hebben vrouwen relatief gezien vaker een flexibel arbeidscontract dan mannen, respectievelijk $15 \%$ en $10 \%$. Dit is in overeenstemming met Pot, Koene \& Paauwe (2001), die stellen dat het aandeel flexwerk ten opzichte van de totale werkgelegenheid voor vrouwen groter is dan voor mannen. Pot et al. (2001) vinden weliswaar lagere aandelen flexwerk voor zowel mannen als vrouwen, maar dit onderzoek maakt gebruik van CBScijfers betreffende de periode 1992-1999.

In 2005 is $49 \%$ van de ruim een half miljoen flexwerkers in Nederland vrouw, terwijl het aandeel vrouwen van werknemers met een vast contract $44 \%$ is (Bierings en Siermann, 2006). Opvallend is dat van alle oproep- en invalkrachten maar liefst 65\% vrouw is. Uitzendkrachten zijn vaker man dan vrouw, terwijl de sekseverschillen voor mensen met een tijdelijk dienstverband klein zijn volgens Bierings en Siermann (2006). De mannelijke uitzendkrachten werken vooral in de sectoren industrie, vervoer en zakelijke dienstverlening, de vrouwen vooral in de horeca en de zorg.

Figuur 6.1

Flexwerkers als percentage van het aantal werknemers naar geslacht, 1996-2006

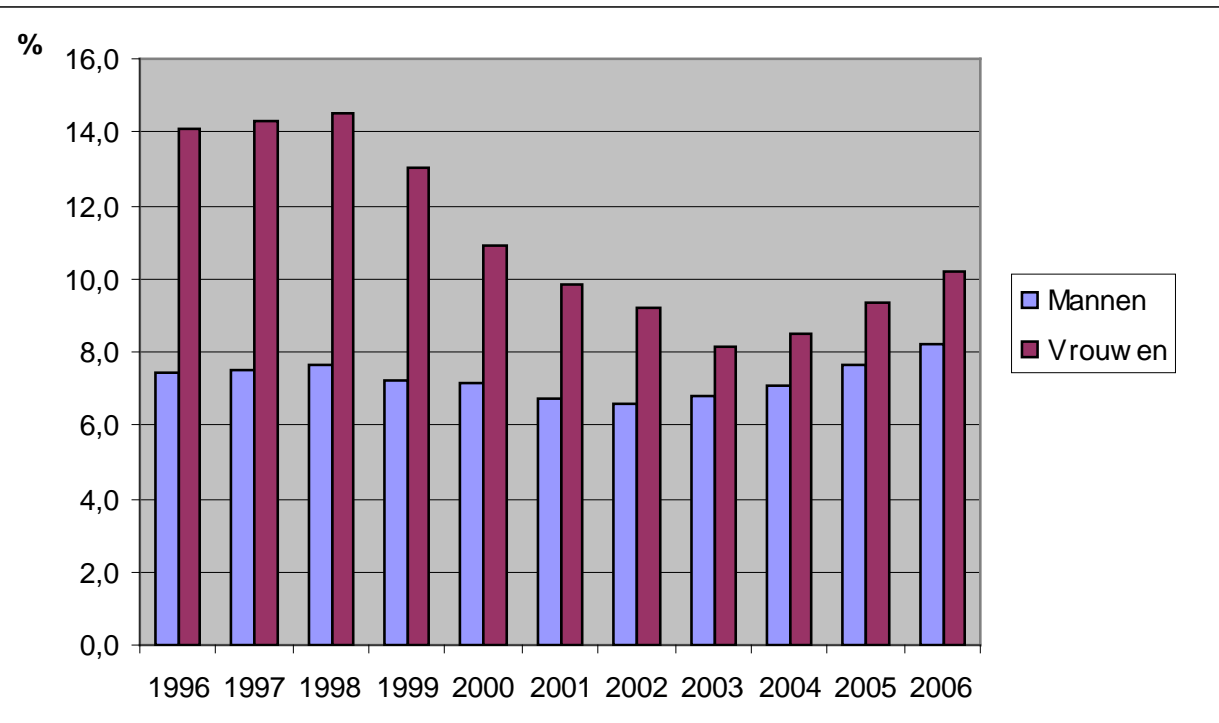

Bron: CBS, Statline

Figuur 6.1 geeft het percentage mannelijke en vrouwelijke werknemers met een flexibel arbeidscontract weer voor de periode tussen 1996 en 2006. Ook hieruit blijkt dat een groter deel van de vrouwen een flexibel contract heeft in vergelijking met mannen. Tussen 1996 en 2006 heeft gemiddeld ruim 7\% van de mannelijke werkzame beroepsbevolking een flexibele contractvorm. Voor vrouwen ligt dit percentage op 11\%. Wel hebben vrouwen sinds 1998 relatief gezien minder vaak een flexibel contract dan voorheen. Het is mogelijk dat het aandeel vrouwelijke flexwerkers veel sterker op de conjunctuur reageert dan het aandeel mannelijke flexwerkers. Gedurende de sterke conjuncturele opleving na 1998 neemt vooral het aandeel vrouwelijke werknemers met een flexibele arbeidsrelatie aanzienlijk af. Vanaf 2003 neemt het aandeel vrouwelijke flexwerkers weer gestaag toe. Bij mannen gebeurde dit 
al een jaar eerder. Zowel bij mannen als vrouwen lijkt het erop dat het aandeel flexwerkers afneemt bij een opgaande conjunctuur en toeneemt bij een neergaande conjunctuur.

In de figuren 6.2 en 6.3 worden de werknemers met een flexibele arbeidsrelatie verder opgesplitst naar verschijningsvorm. Er zijn enkele opvallende verschillen tussen mannen en vrouwen. Zoals blijkt uit figuur 6.2 behoren mannelijke flexwerkers voornamelijk tot de uitzendkrachten en tot de groep 'overige flexibelen'. Dit zijn vooral degenen met een tijdelijk dienstverband korter dan een jaar. Van de mannelijke flexwerkers zijn er in deze periode slechts weinig oproep- en invalkrachten (17\%).

Figuur 6.2

Mannelijke flexwerkers naar verschijningsvorm,1996-2006

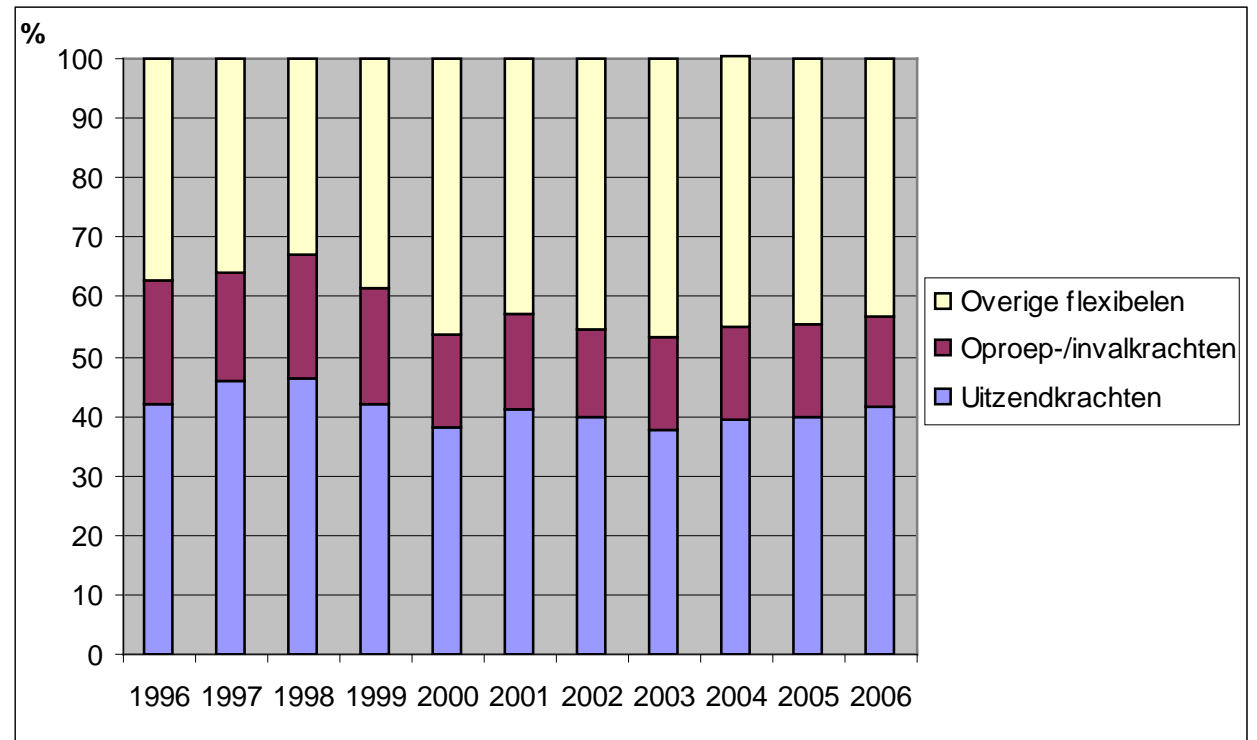

Bron: CBS, Statline

\section{Figuur 6.3}

Vrouwelijke flexwerkers naar verschijningsvorm,1996-2006

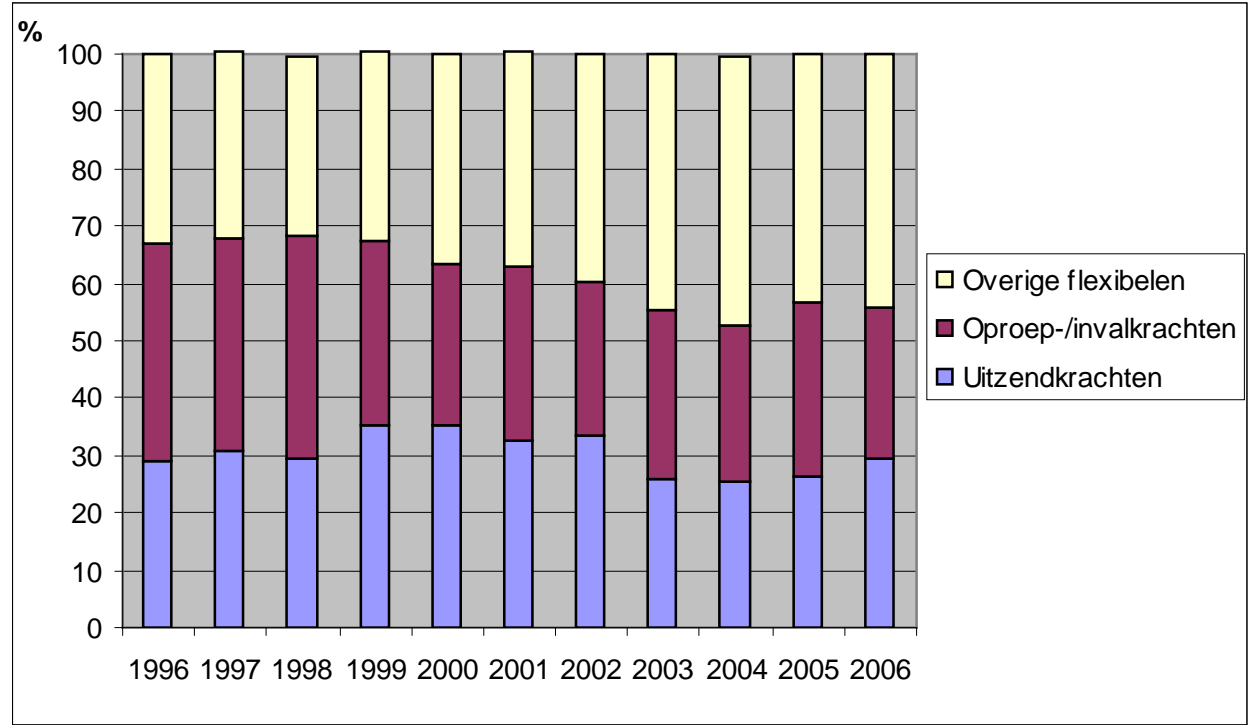

Bron: CBS, Statline 
Figuur 6.3 differentieert vrouwelijke flexwerkers naar verschijningsvorm. In vergelijking met mannen zijn vrouwen minder vaak werkzaam als uitzendkracht en vaker als oproep- of invalkracht. Gedurende de periode 1996-2006 kan gemiddeld een kleine 40\% van de vrouwelijke flexwerkers gerekend worden tot de groep 'overige flexibelen'. Verder kan uit de figuur geconcludeerd worden dat er in deze periode een min of meer gelijk aantal vrouwelijke 'oproep- en invalkrachten' en uitzendkrachten actief is, gemiddeld respectievelijk $31 \%$ en 30\%. Daarnaast werken mannelijke flexwerkers meer uren dan vrouwelijke flexwerkers, respectievelijk 18 uur en 14 uur per week (CBS, 2005).

Flexwerkers zijn vaak relatief jong en nog schoolgaand (Bierings en Siermann, 2006). In 2005 was de gemiddelde leeftijd van flexwerkers 31 jaar, terwijl de gemiddelde leeftijd van werknemers met een vast contract 40 jaar was. Van alle flexwerkers zijn vooral de oproepen invalkrachten behoorlijk jong. De helft van deze groep is namelijk jonger dan 25 jaar. Verder zijn er veel laagopgeleide personen onder de flexwerkers (Delsen, 1995; Pot, Koene en Paauwe, 2001). Een laatste achtergrondkenmerk dat relatief vaak voorkomt bij flexwerkers is een allochtone achtergrond. Volgens De Beer (1996) heeft een zevende tot een vijfde van de totale allochtone beroepsbevolking een flexibele betrekking, terwijl een tiende van de gehele beroepsbevolking van allochtone afkomst is.

\section{Achtergrondkenmerken uitzendkrachten}

Veel recente informatie over uitzendkrachten is te vinden in het rapport 'Instroom uitzendkrachten 2006', dat ECORYS jaarlijks in opdracht van de ABU uitvoert (Donker van Heel, Van Nuland \& Van der Ende, 2007). Hierbij dient te worden opgemerkt dat er in de jaren 1994, 2003 en 2005 geen metingen gedaan zijn.

Figuur 6.4

Percentage vrouwelijke uitzendwerkers,1993-2006

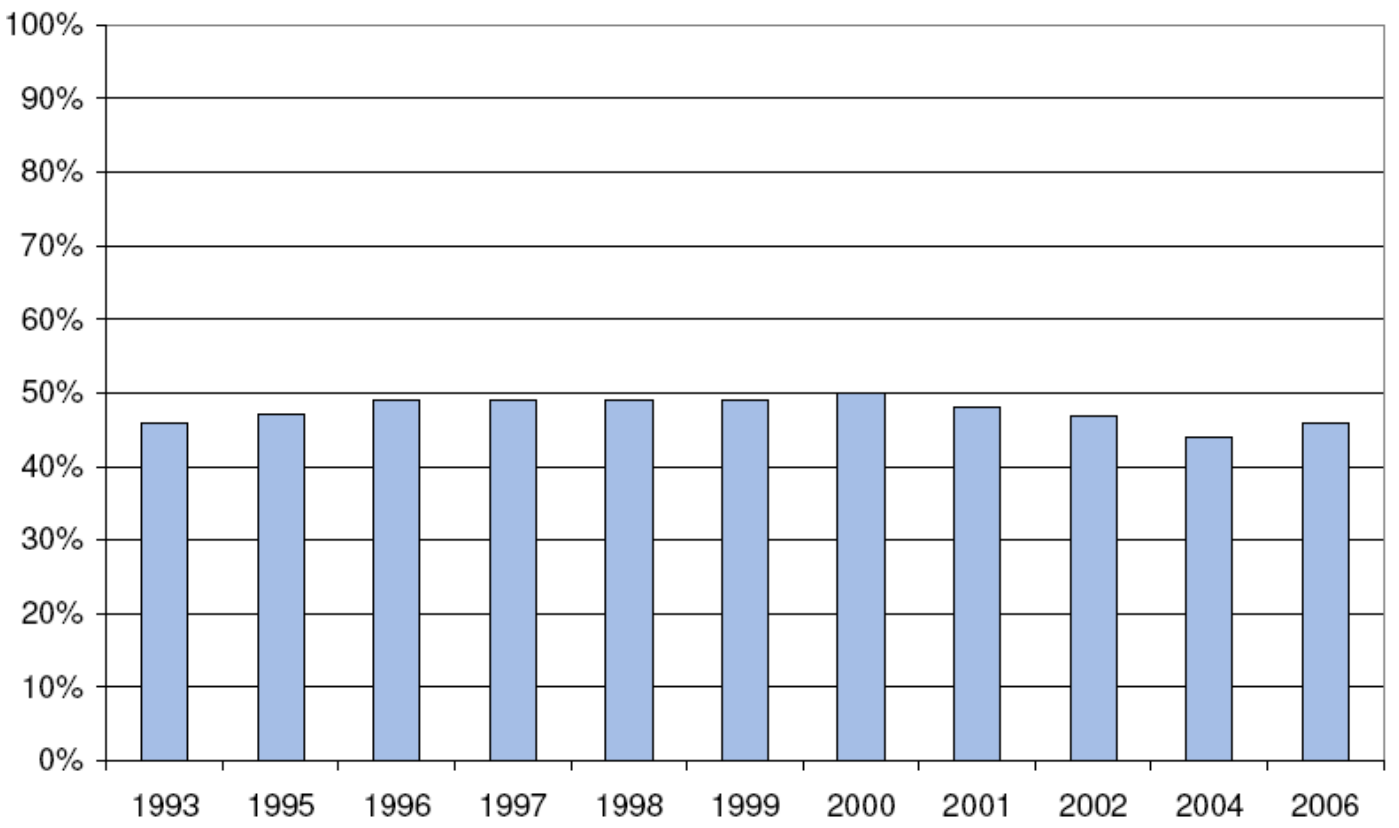

Bron: Instroom uitzendkrachten 2006 
In figuur 6.4 is het percentage vrouwelijke uitzendkrachten weergegeven. Uit de figuur kan geconcludeerd worden dat mannen in het algemeen vaker uitzendwerk doen dan vrouwen. Tussen 1996 en 2000 waren er echter bijna evenveel vrouwen als mannen die een contract op uitzendbasis hadden.

Figuur 6.5 laat de leeftijdsopbouw van uitzendkrachten zien. Uit de figuur blijkt dat uitzendkrachten relatief jong zijn. In bijna alle jaren tussen 1996 en 2006 bevindt meer dan de helft van alle uitzendkrachten zich in de leeftijdscategorie 15-24 jaar. Gedurende deze periode is er voor deze jongste leeftijdscategorie echter wel een dalende tendens waarneembaar van circa 60\% in 1993 naar 48\% in 2006. Het aandeel 45-plussers laat daarentegen een stijgende lijn zien. In 2006 is $12 \%$ van alle uitzendkrachten 45 jaar of ouder. Hieruit blijkt dat ook onder de uitzendkrachten de vergrijzing toeslaat.

Figuur 6.5

Leeftijdsopbouw uitzendkrachten,1993-2006

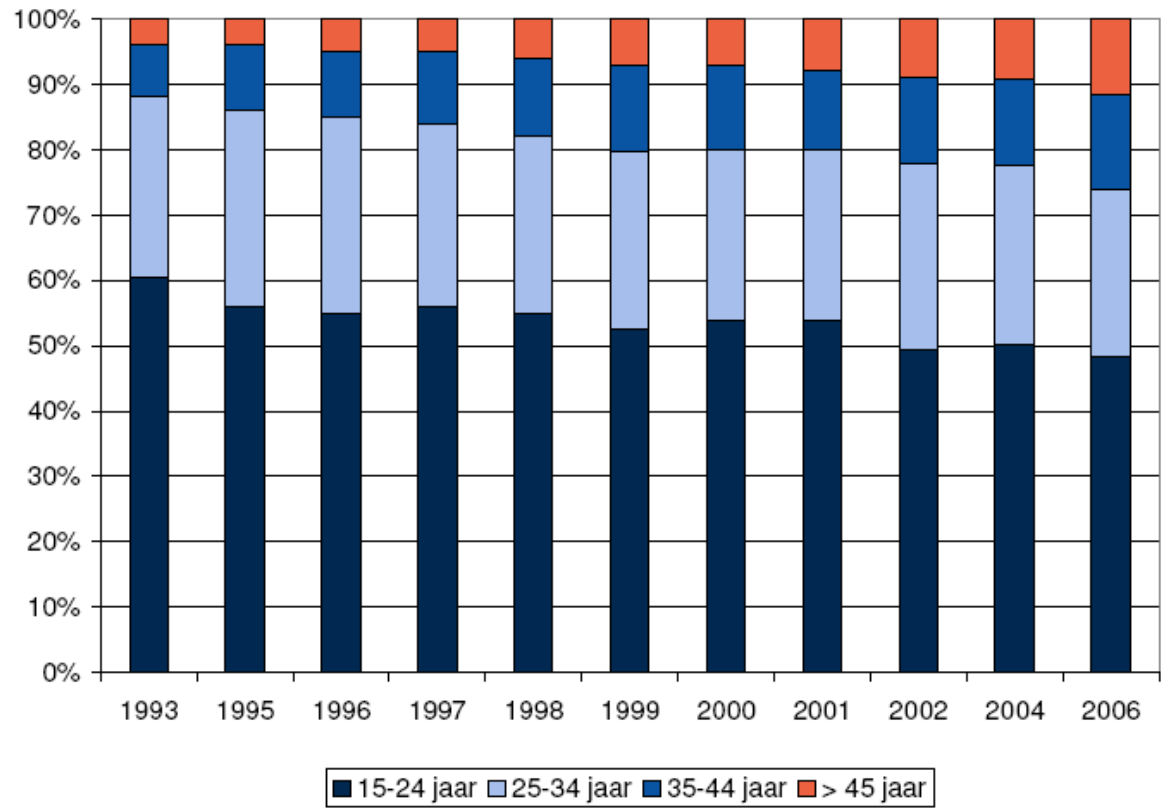

Bron: Instroom uitzendkrachten 2006

Figuur 6.6 differentieert uitzendkrachten naar opleidingsniveau. Met betrekking tot de hoogst genoten opleiding van uitzendkrachten in Nederland, valt op dat steeds meer uitzendkrachten hoogopgeleid zijn (Donker van Heel, Van Nuland \& Van der Ende, 2007). In 2006 is dit aandeel van mensen met ten minste een HBO-opleiding opgelopen tot $23 \%$. Dit is opvallend te noemen, omdat uitzendwerk vaak met laaggeschoolde arbeid geassocieerd wordt. Het aandeel laaggeschoolde uitzendkrachten neemt echter af tot $28 \%$. De grootste groep uitzendkrachten wordt in deze periode gevormd door degenen met een HAVO-, VWOof MBO-diploma. Het gaat hierbij om iets minder als de helft van alle uitzendkrachten. 
Figuur 6.6

Hoogst genoten opleiding van uitzendkrachten, 2002, 2004, 2006

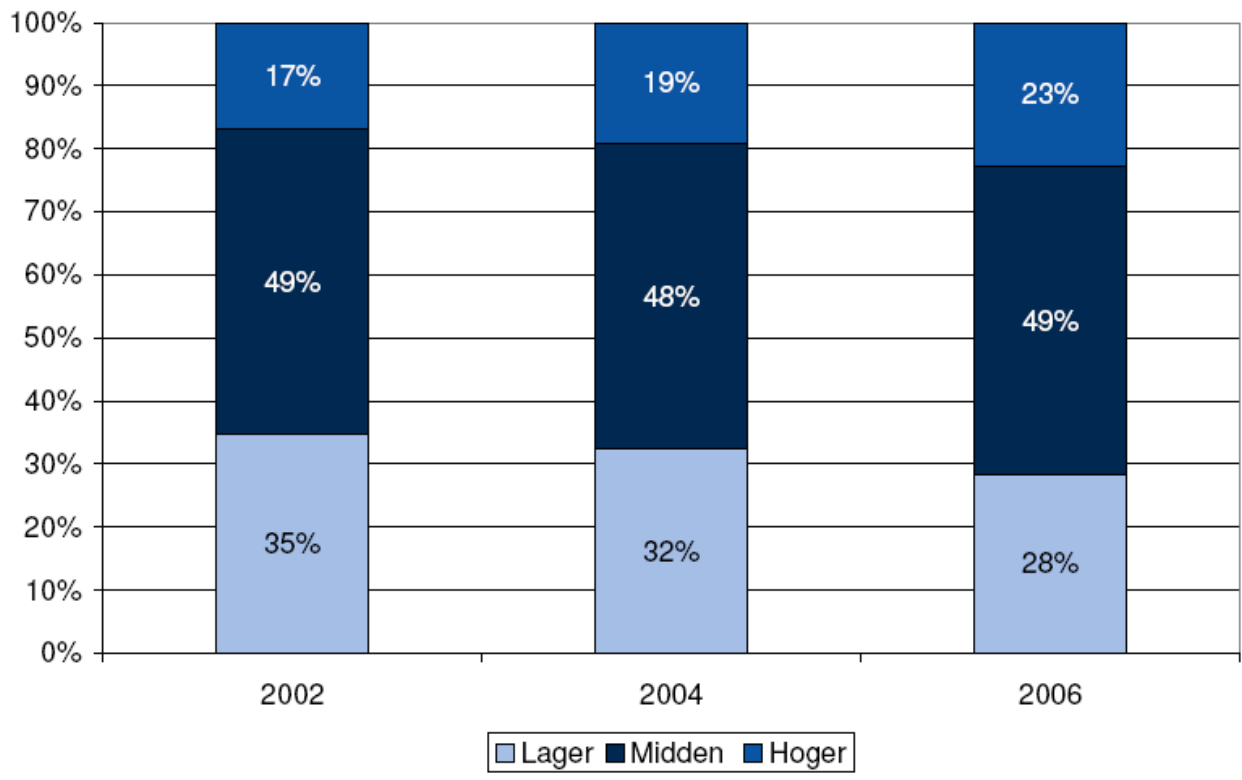

Bron: Instroom uitzendkrachten 2006

Figuur 6.7 laat de ontwikkeling van de thuissituatie van uitzendkrachten zien. Uit de figuur blijkt dat er in 2006 minder thuiswonenden onder de uitzendkrachten zijn dan voorheen. Het aandeel uitzendkrachten dat getrouwd is of samenwoont, is vrij stabiel gedurende de hele periode. In 2006 is er wel een stijging te zien in het aantal alleenstaanden.

Figuur 6.7

Thuissituatie van uitzendkrachten,1993-2006

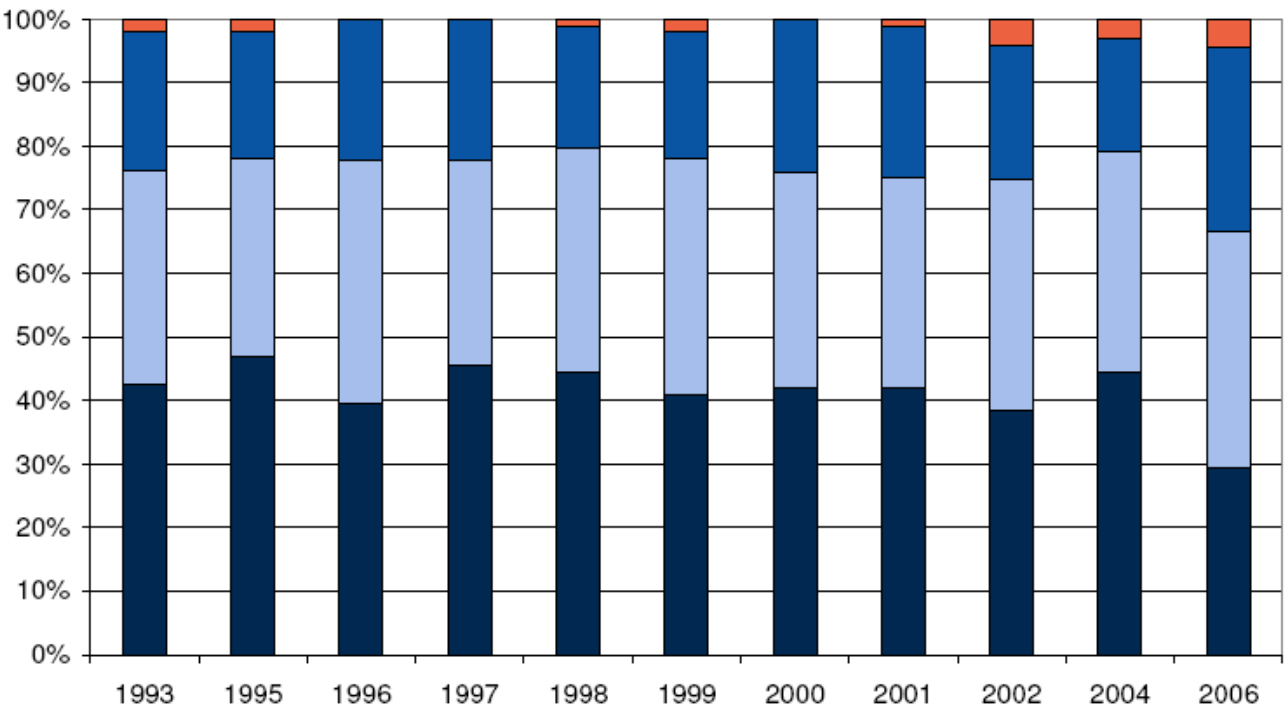

$\square$ Woont thuis bij ouders $\square$ Getrouwd/vaste partner $\square$ Alleen $\square$ Anders

Bron: Instroom uitzendkrachten 2006 
Figuur 6.8 geeft de ontwikkeling van het percentage kostwinners onder uitzendkrachten weer. Bijna een kwart van alle uitzendkrachten vervult in 2006 de rol van kostwinner. Dit percentage is nog iets lager dan in 1993, terwijl in de tussenliggende jaren steeds meer dan $30 \%$ van alle uitzendkrachten kostwinner was.

Figuur 6.8

Percentage kostwinners onder uitzendkrachten, 1993-2006

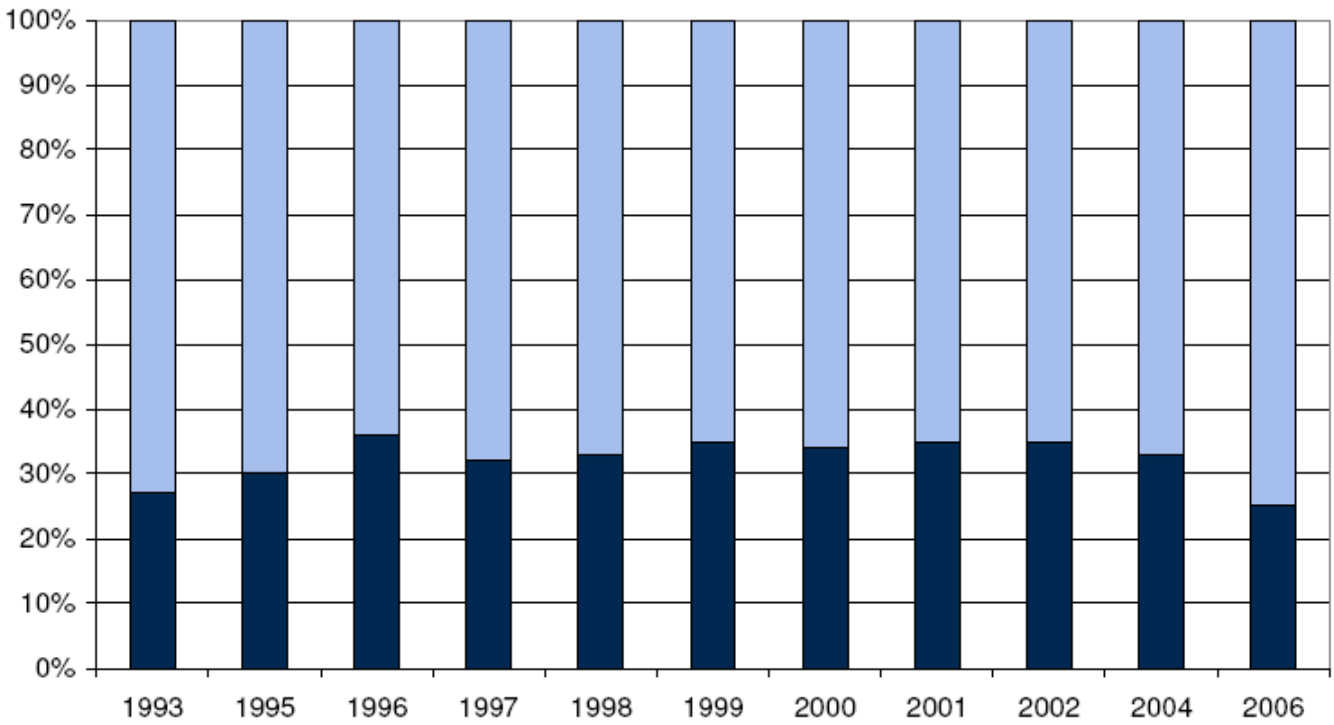

- Kostwinner $\quad$ Geen kostwinner

Bron: Instroom uitzendkrachten 2006

Figuur 6.9

Percentage etnische minderheden onder uitzendkrachten, 1991-2006

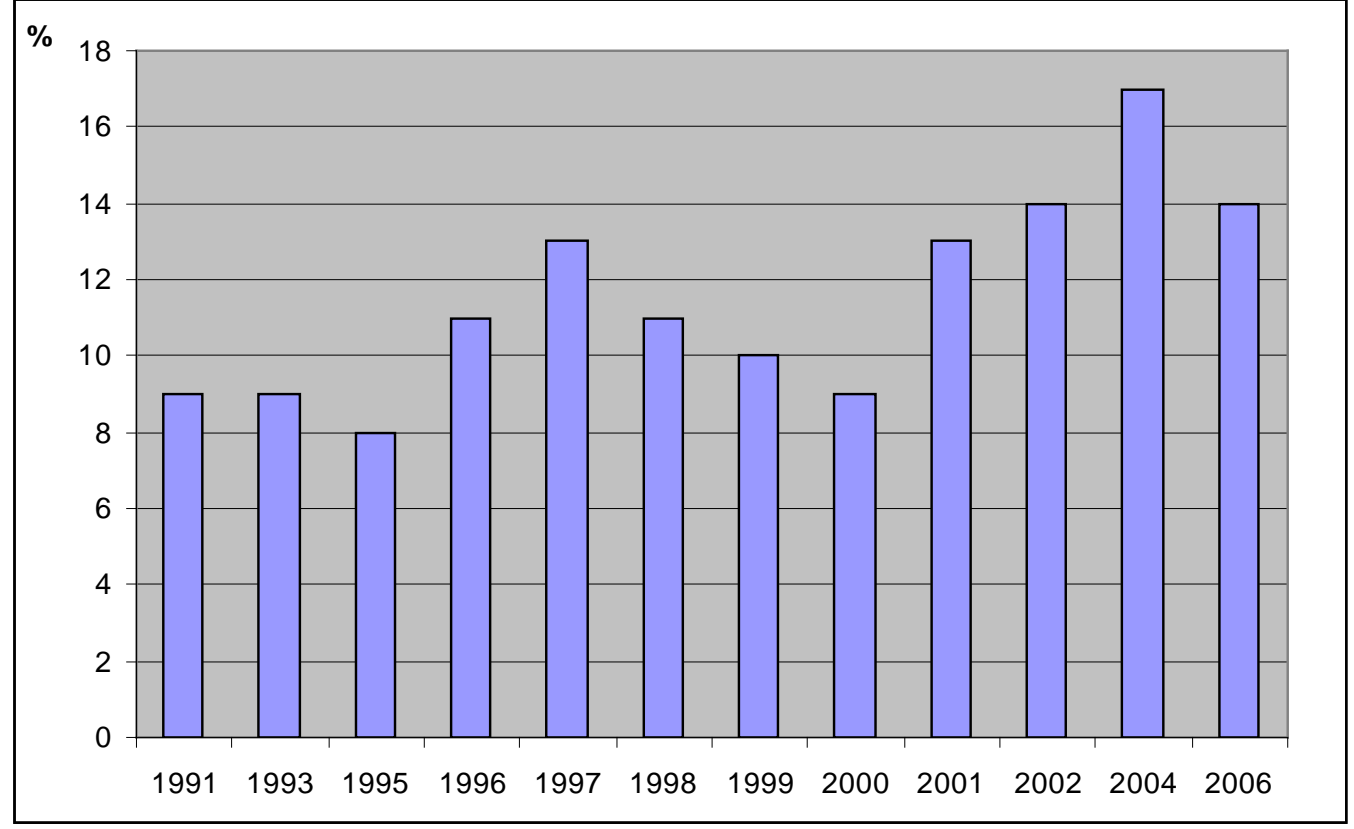

Bron: Instroom uitzendkrachten 2006 
Figuur 6.9 geeft het aandeel uitzendkrachten weer dat behoort tot een etnische minderheidsgroep. Dit aandeel schommelt nogal tussen 1991 en 2006. Wel is er sprake van een stijgende tendens. Tussen 1991 en 2004 is hun aandeel bijna verdubbeld. In 2006 is er echter weer een daling van het aandeel allochtone uitzendkrachten, tot $14 \%$ van het totale aantal uitzendkrachten. ${ }^{11}$

Tot slot van deze paragraaf komen de kenmerken aan de orde van uitzendkrachten waarvan aangenomen wordt dat zij minder kansen op de arbeidsmarkt hebben: de zogenaamde bijzondere doelgroepen. Hiertoe worden gerekend personen van 45 jaar en ouder, allochtonen, langdurig werklozen en (gedeeltelijk) arbeidsongeschikten (Donker van Heel, Van Nuland en Van der Ende, 2007). Het aandeel van deze bijzondere doelgroepen fluctueert behoorlijk tussen 1991 en 2006, zoals blijkt uit figuur 6.10. In 2006 vormen de bijzondere doelgroepen $27 \%$ van alle uitzendkrachten (gecorrigeerd voor dubbeltellingen). Etnische minderheden vormen met $14 \%$ het leeuwendeel van de bijzondere doelgroepen gevolgd door ouderen (12\%), langdurig werklozen (3\%) en (gedeeltelijk) arbeidsongeschikten (2\%).

\section{Figuur 6.10}

Percentage bijzondere doelgroepen onder uitzendkrachten, 1991-2006

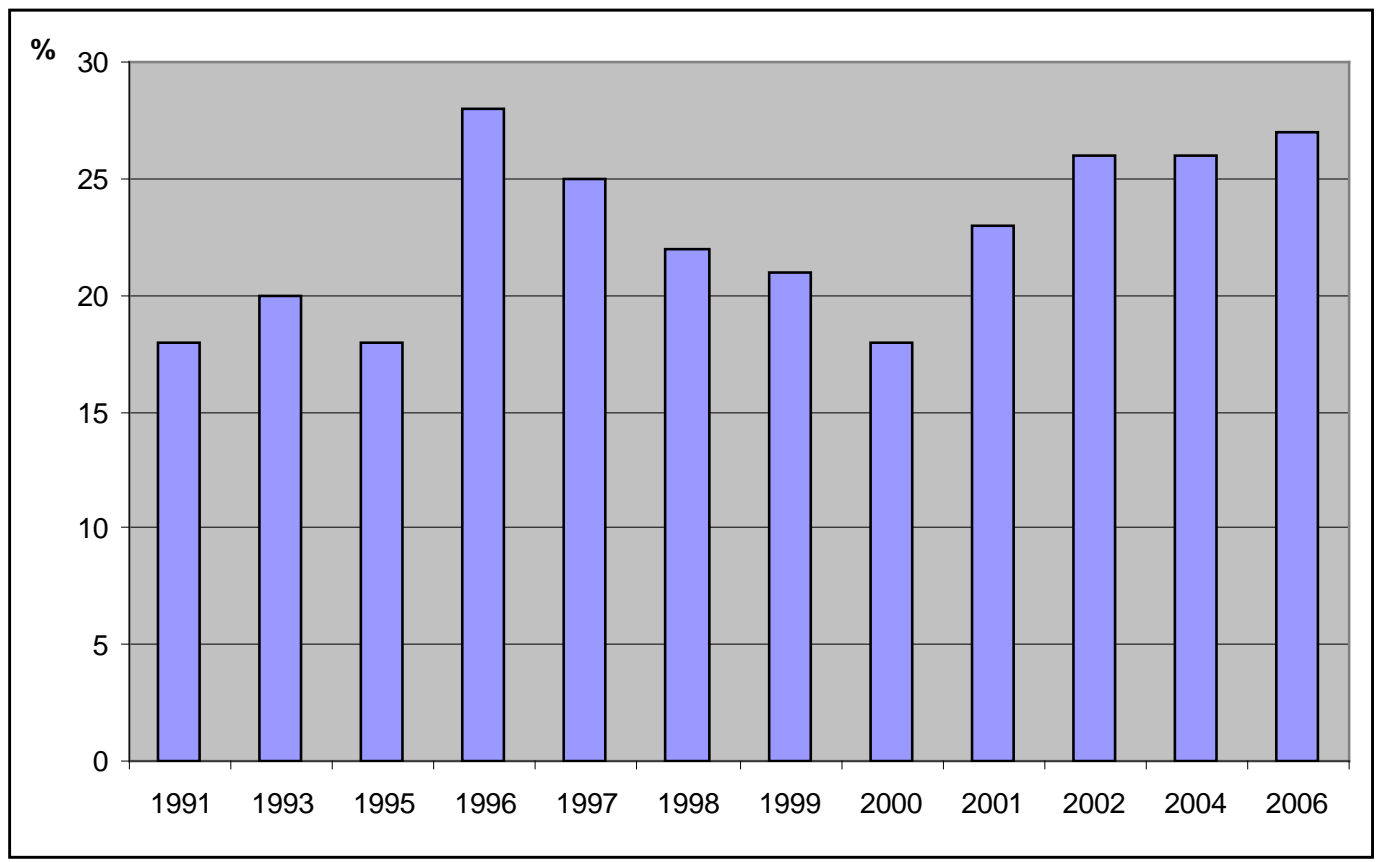

Bron: Instroom uitzendkrachten 2006

11. Op basis van definitie van Stichting van Arbeid (STAR). Op basis van de definitie van de Wet Samen zou in 2006 18\% als allochtoon aangemerkt worden. 


\section{Ontwikkeling van het flexwerk in Nederland}

\subsection{Flexwerk op macroniveau}

Gegeven de grote aandacht voor het stimuleren van de flexibilisering van arbeid zou men kunnen verwachten dat het aandeel flexibele arbeidskrachten flink is toegenomen. Uit paragraaf 3 werd duidelijk dat het aantal flexibele arbeidskrachten in veel OECD-landen sterk gegroeid is in de jaren negentig. Figuur 7.1 geeft het aandeel vaste en flexibele arbeidskrachten weer voor de periode 1996-2006. Uit de figuur blijkt in het geheel niet dat de flexibilisering van de arbeid in de laatste tien jaar is voortgeschreden. Voor de gehele periode geldt dat het relatieve aantal personen dat in vaste dienst werkt nog iets boven de 90\% ligt. Er lijkt wel een relatie met de conjuncturele ontwikkeling te zijn. Zoals eerder opgemerkt lijkt het aandeel flexwerkers af te nemen bij een opgaande conjunctuur, en toe te nemen bij een neergaande conjunctuur.

Figuur 7.1

Percentage werknemers met een vast of flexibel contract, 1996-2006

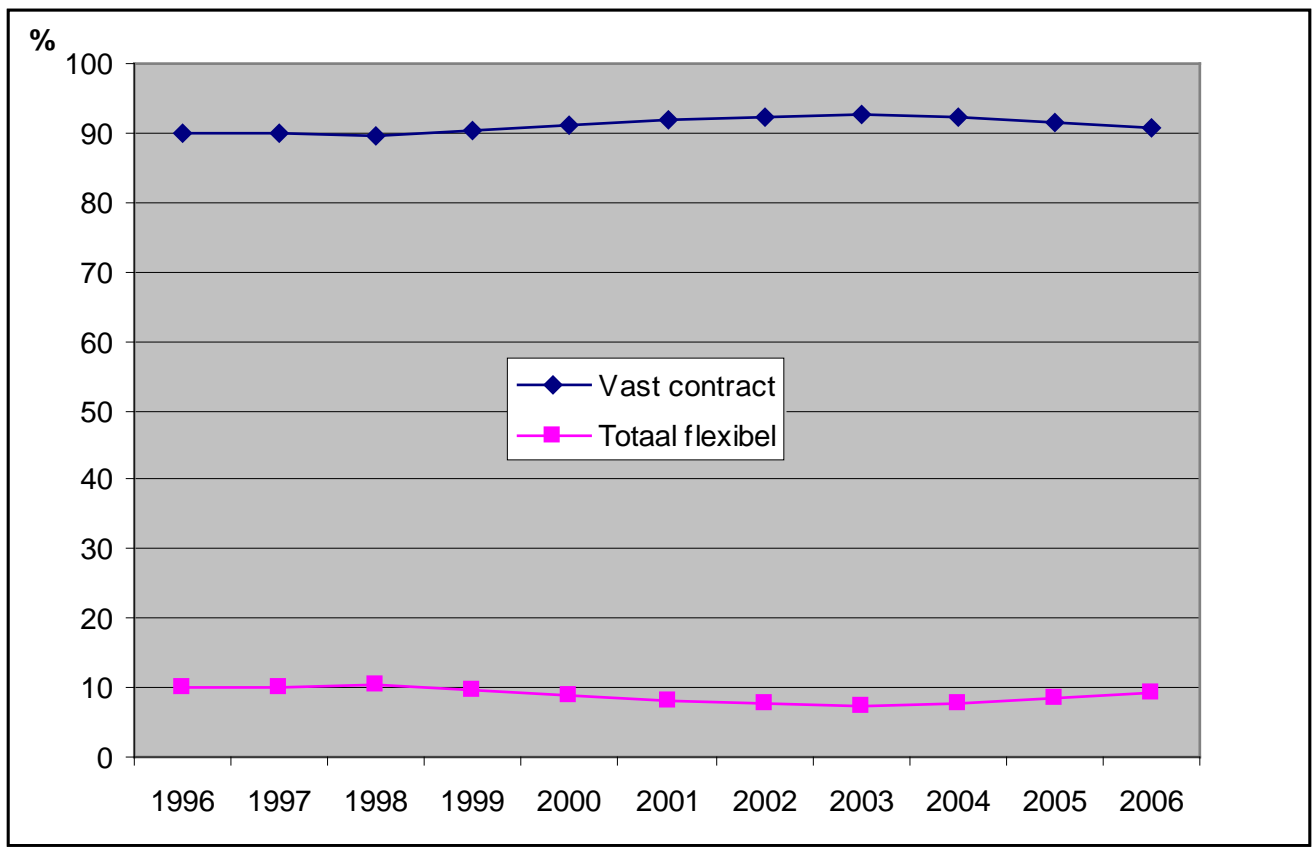

Bron: CBS (EBB)

In figuur 7.2 wordt vervolgens het aantal werknemers met een vast dan wel flexibel dienstverband weergegeven, waarbij het aantal werknemers in het jaar 2000 op 100 is gesteld. De figuur geeft het 'business cycle effect' op flexibele arbeid weer. Terwijl het aantal personen dat in vaste dienst werkt gestaag stijgt van 1996 tot 2002, beweegt het aantal flexibele arbeidskrachten met de conjunctuur mee. ${ }^{12} \mathrm{Na} 2002$ neemt ook het aantal vaste arbeidskrachten enigszins af.

12. Zie voor een uitgebreide analyse over de relatie tussen flexibele arbeid en conjunctuur in Nederland Zijl et al. (2003). 


\section{Figuur 7.2}

Aantal werknemers met een vast of flexibel contract, 1996-2006 $(2000=100)$

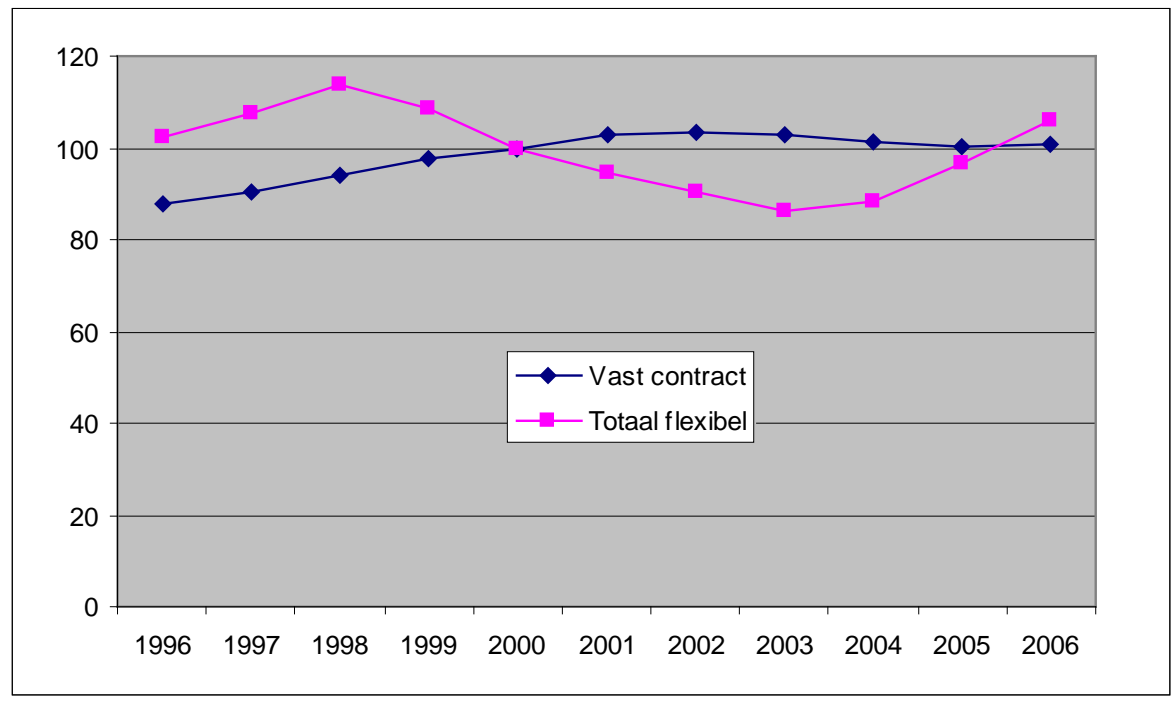

Bron: CBS (EBB)

\section{Figuur 7.3}

Aantal banen van werknemers naar arbeidsrelatie, 1987-2007

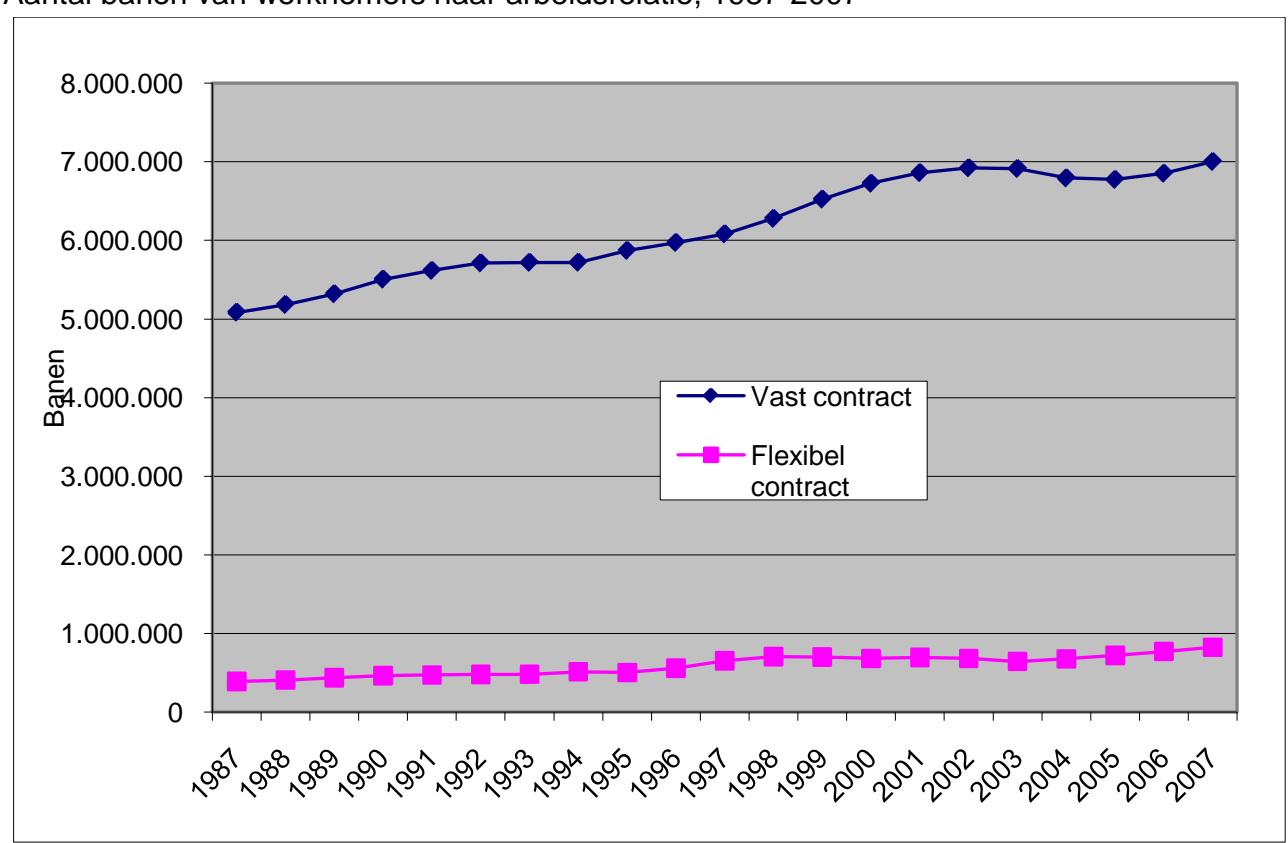

Bron: CBS

Behalve het aantal personen dat in vast c.q. flexibel dienstverband werkt kan er ook gekeken worden naar de ontwikkeling van het aantal banen in beide contractvormen. Figuur 7.3 geeft het aantal banen van werknemers naar arbeidsrelatie weer voor de periode 19872007. ${ }^{13}$ In deze periode waren er gemiddeld 595.000 banen per jaar die door flexwerkers

13. Volgens het CBS zijn werknemers personen die in een bepaalde periode arbeid verrichten voor loon of salaris, in geld of in natura. Dit is dus exclusief de zelfstandigen, freelancers en meewerkenden in een bedrijf. Het aantal banen in een jaar is het gemiddelde aantal banen in dat jaar. Dit betekent dat een baan 
ingevuld werden, tegenover 6.163 .500 banen door werknemers in vaste dienst. Zowel het aantal banen van werknemers in vaste dienst als het aantal banen van werknemers met een flexibel contract is in deze periode toegenomen.

Figuur 7.4 geeft het gemiddelde aandeel flexibele banen van werknemers weer per jaar. Voor de periode 1987-2007 is er een stijgende tendens van het aandeel flexibele banen, met pieken in $1998(10,1 \%)$ en 2007 (10,6\%). Over de gehele periode wordt gemiddeld $8,8 \%$ van alle banen flexibel ingevuld. De pieken in het aandeel flexibele arbeid zijn verklaarbaar uit het aantrekken van de economie na een periode van lage economische groei in respectievelijk 1992/93 en 2002/03, waardoor werkgevers in eerste instantie relatief vaak flexibele arbeidskrachten aanstellen. Nadat de arbeidsmarkt zich heeft hersteld en de werkloosheid terugloopt naar het natuurlijke niveau, kan er krapte op de arbeidsmarkt ontstaan. Werknemers kunnen dan hogere eisen stellen aan de secundaire arbeidsvoorwaarden, waaronder de contractduur. Derhalve zien we na 1998 het aandeel flexibele arbeid weer dalen. Vervolgens daalt het aandeel verder omdat de economische groei stagneert in 2002/03, waardoor flexibele arbeidskrachten als eerste op straat komen te staan. Dit leidt tot een nieuw dieptepunt van het aandeel flexibele arbeid in 2003, dat echter nog steeds hoger is dan het aandeel voor de jaren 1996. Na 2003 stijgt het aandeel flexibele arbeid tot een absoluut hoogtepunt in 2007 omdat de economische groei flink aantrekt. De verwachting is dat het aandeel flexibele arbeid in 2008 is gedaald vanwege de grote arbeidsmarktkrapte, en vervolgens verder daalt door de economische crisis waardoor flexibele arbeidskrachten weer als eerste aan de kant komen te staan.

Figuur 7.4

Aandeel flexibele banen onder werknemers per jaar, 1987-2007

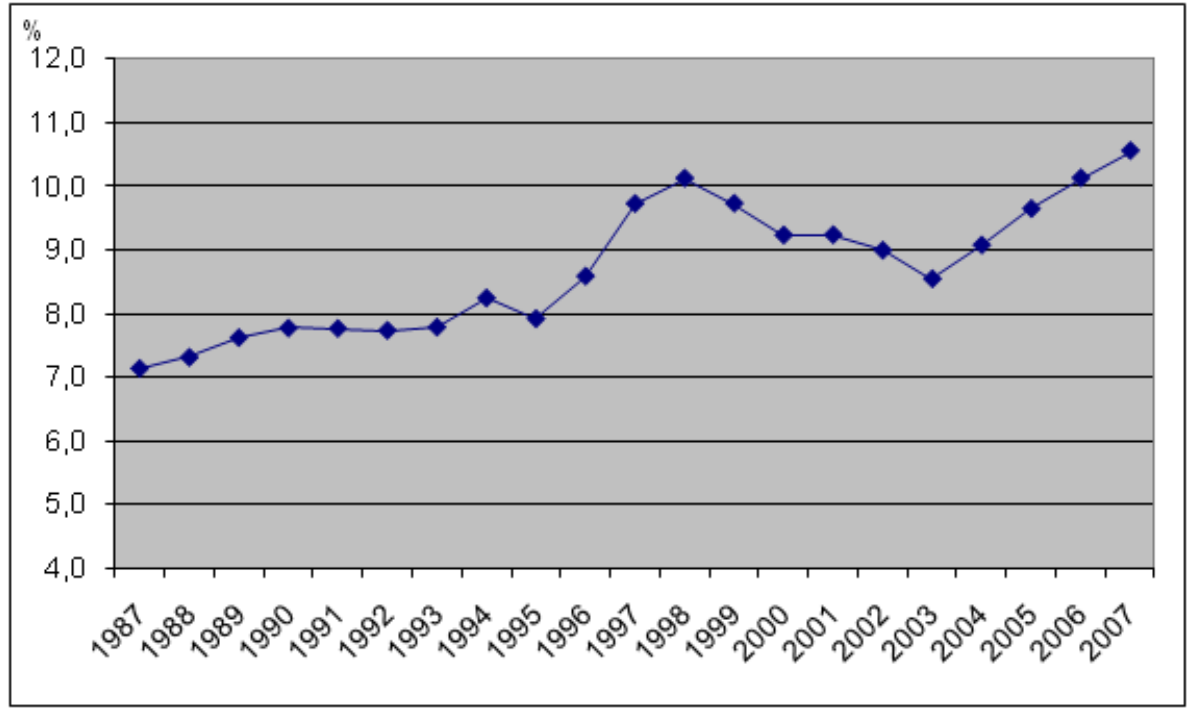

Bron: CBS

alleen meetelt voor de dagen dat deze bezet is. Flexibele banen zijn banen van inval-, oproep- en uitzendkrachten en van werknemers met wie een tijdelijke arbeidsduur is overeengekomen. Alle overige banen zijn banen met een vaste arbeidsduur. 
Aangezien er op macroniveau gedurende het laatste decennium nauwelijks veranderingen hebben plaatsgevonden met betrekking tot flexwerk, is het interessant om te onderzoeken of er daarentegen wel veranderingen hebben plaatsgevonden binnen de verschillende sectoren, opleidingen en beroepsklassen. Daarnaast is het interessant om te kijken of er veranderingen binnen het flexwerk als zodanig hebben plaatsgevonden.

\subsection{Ontwikkeling flexwerk naar sector}

Om te achterhalen wat de invloed van een sector is, bekijken we allereerst per sector hoe het aandeel flexwerk zich gedurende laatste jaren ontwikkeld heeft. Vervolgens verbijzonderen we de data over flexwerk ook nog naar verschijningsvorm om te achterhalen of er binnen flexibele arbeid nog trends waarneembaar zijn. Voor de periode 1996-2006 heeft gemiddeld $12,8 \%$ van de werknemers een flexibel contract. Tabel 7.1 geeft weer in welke sectoren gemiddeld genomen het grootste aandeel flexwerkers actief is. Tevens staat in deze tabel het werkgelegenheidsaandeel per sector vermeld, zodat een duidelijk beeld gevormd kan worden over de werkelijke omvang van het flexwerk in de betreffende sectoren. ${ }^{14}$

Tabel. 7.1

Sectoren met grootste aandeel flexwerkers, 1996-2006

\begin{tabular}{lcc}
\hline & $\begin{array}{c}\text { Aandeel } \\
\text { flexwerkers (\%): }\end{array}$ & $\begin{array}{c}\text { Werkgelegenheids- } \\
\text { aandeel sector (\%): }\end{array}$ \\
\hline Horeca & 39,3 & 3,5 \\
Landbouw en visserij & 31,4 & 1,7 \\
Overige commerciële & & \\
dienstverlening & 21,3 & 2,1 \\
Vlees- en visverwerking & 19,5 & 0,5 \\
Grafische industrie & 18,4 & 1,6 \\
Handel en reparatie & 15,0 & 15,2 \\
\hline Bron: CBS (EBB) & &
\end{tabular}

Uit de gegevens in de tabel blijkt dat er in de horeca relatief gezien de meeste flexwerkers werkzaam zijn (39,3\%). Het is opmerkelijk dat van al deze sectoren met een groot aandeel flexwerkers er slechts één grote sector is qua werkgelegenheid. Handel en reparatie zorgt namelijk voor meer dan $15 \%$ van de totale werkgelegenheid, terwijl een gemiddelde sector voor $3 \%$ van de totale werkgelegenheid zorgt. Uit tabel 7.1 kan dus geconcludeerd worden dat er in de kleinere sectoren relatief meer flexwerkers actief zijn.

\section{Aandeel flexwerk per jaar}

Hierna wordt de ontwikkeling van het aandeel flexwerkers besproken in de zes sectoren met het grootste aandeel flexwerkers. Zo geeft figuur 7.5 bijvoorbeeld de schommelingen weer in het aandeel flexwerkers dat werkzaam is in de horeca (1996-2006).

14. Het werkgelegenheidsaandeel van de betreffende sector geeft aan welk aandeel van de totale werkgelegenheid deze sector vertegenwoordigt ten opzichte van de werkgelegenheid in alle sectoren samen. Zo zorgt de horeca bijvoorbeeld voor 3,5\% van de totale werkgelegenheid in Nederland. 
Figuur 7.5

Aandeel flexwerkers in horeca, 1996-2006

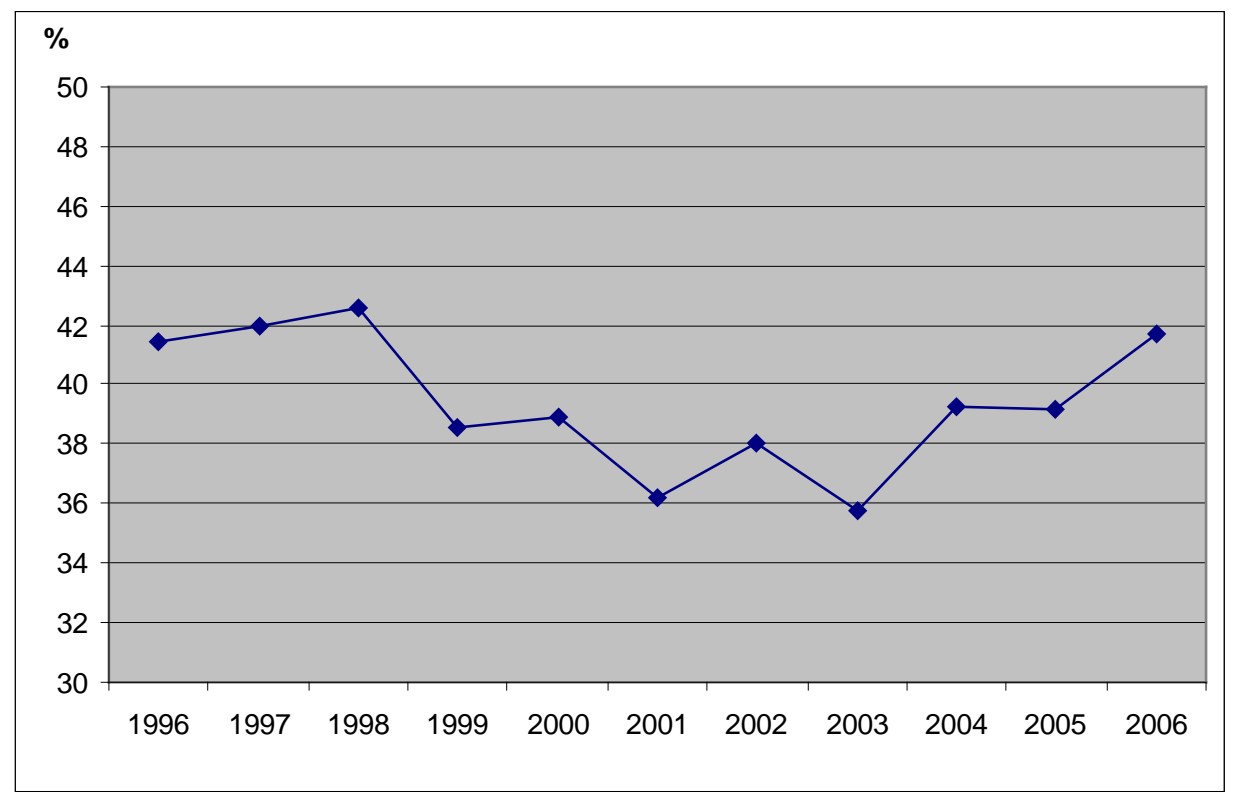

Bron: CBS (EBB)

Figuur 7.6 vertoont de schommelingen van het aandeel flexwerkers in de landbouw en visserij. Er zijn in deze sector drie pieken: in 1998, 2001 en 2005. Van alle jaren in de onderzoeksperiode is in 1998 het grootste aandeel flexwerkers in deze sector actief (35\%). Hierna is een licht dalende trend waarneembaar.

\section{Figuur 7.6}

Aandeel flexwerkers in landbouw en visserij, 1996-2006

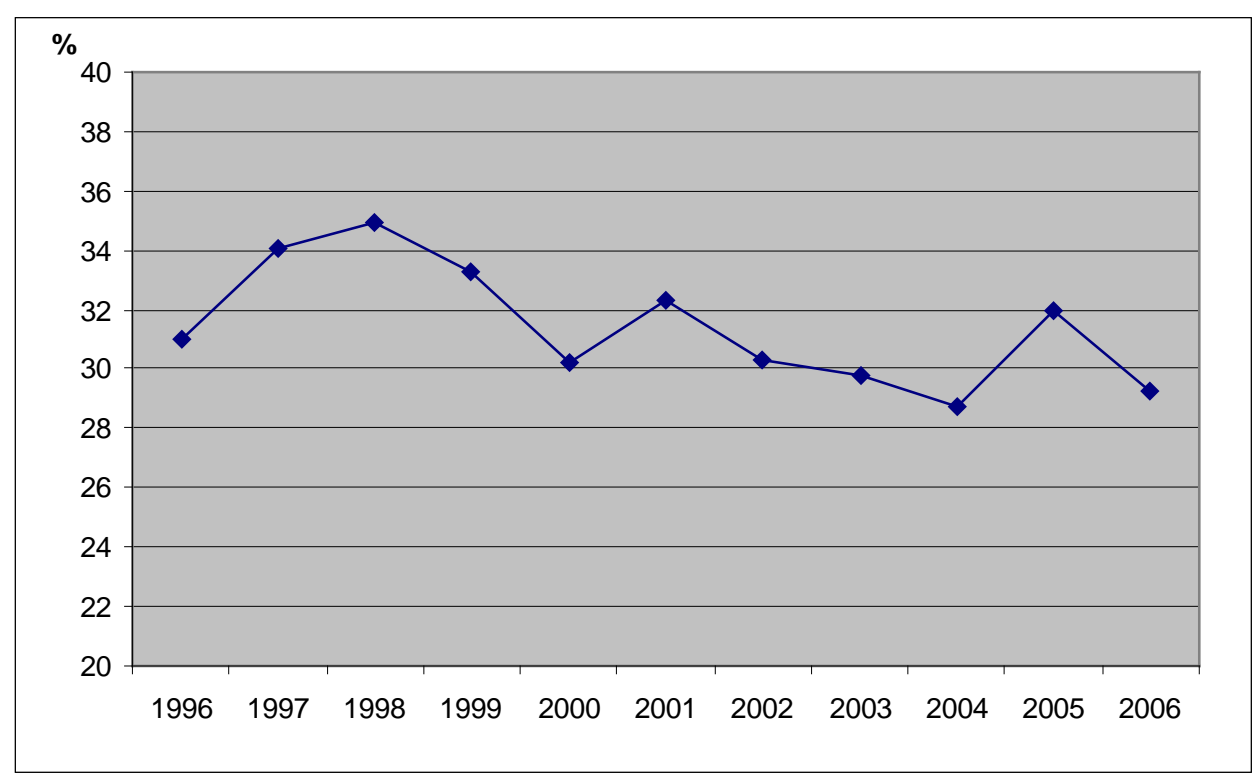

Bron: CBS (EBB)

Een andere sector met relatief gezien veel flexibele arbeidskrachten is de 'overige commerciële dienstverlening'. Uit figuur 7.7 kan geconcludeerd worden dat het aandeel 
flexwerkers in deze sector sinds 1996 aanzienlijk afgenomen is. Met name in 2000 liep dit aandeel flink terug.

\section{Figuur 7.7}

Aandeel flexwerkers in overige commerciële dienstverlening, 1996-2006

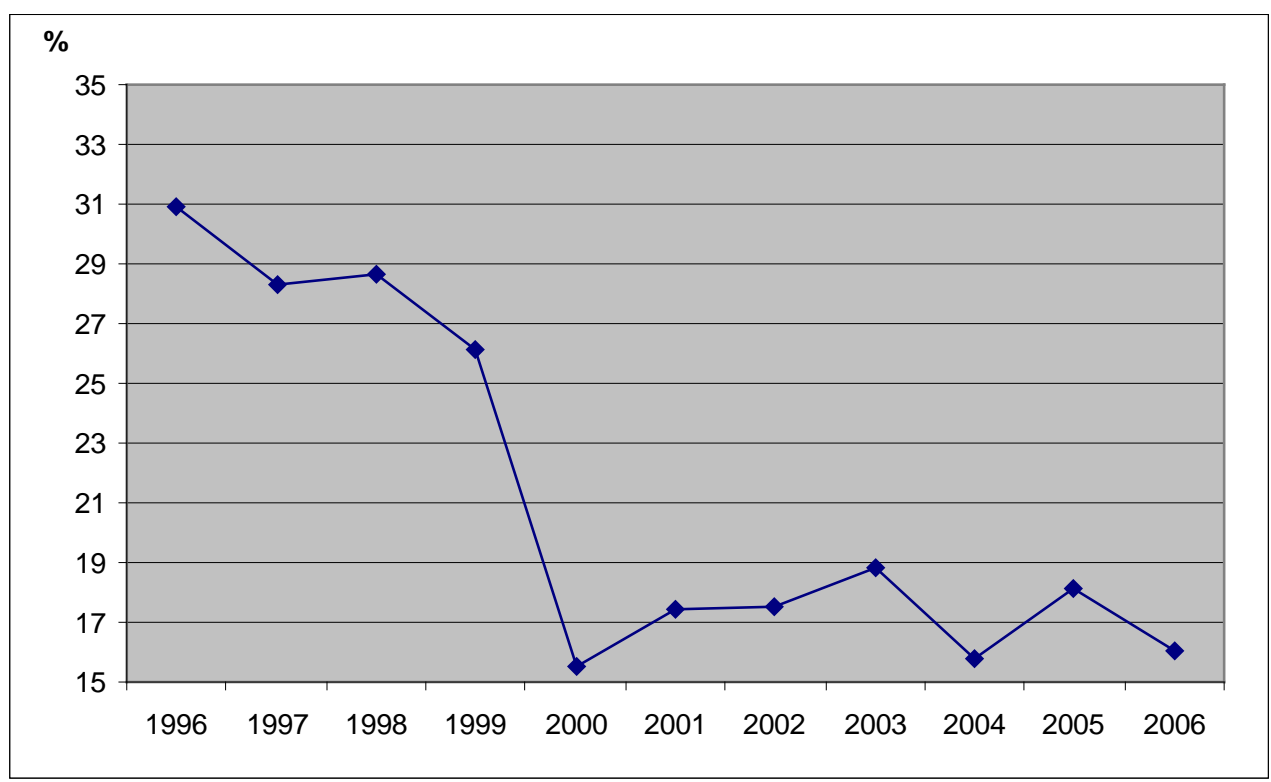

Bron: CBS (EBB)

Het aandeel flexwerkers dat werkzaam is in de vlees- en visverwerking fluctueert nogal, zoals te zien is in figuur 7.8. Vooral tegen het einde van de onderzoeksperiode zijn er behoorlijke fluctuaties zichtbaar. In het algemeen kan gesteld worden dat er sprake is van een licht dalende trendlijn.

\section{Figuur 7.8}

Aandeel flexwerkers in vlees- en visverwerking, 1996-2006

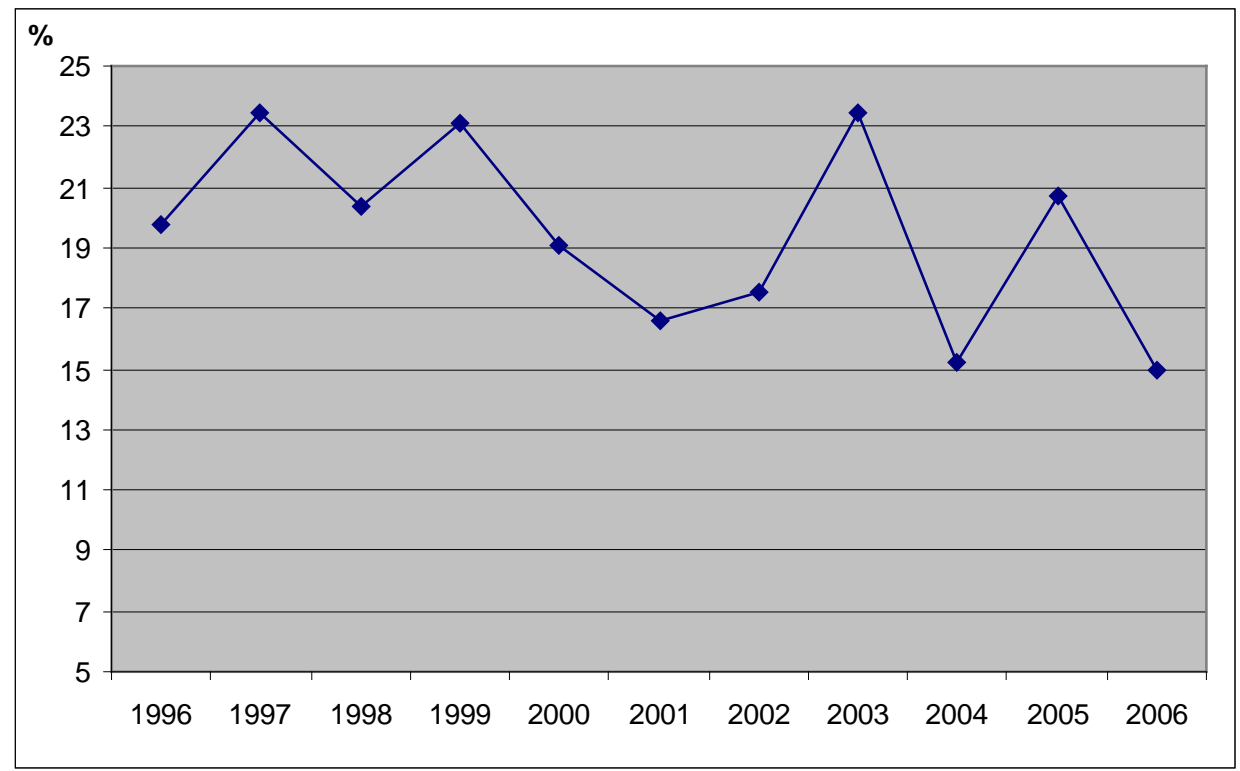

Bron: CBS (EBB) 
Figuur 7.9 geeft het aandeel flexibele arbeidskrachten weer in de grafische industrie. In tegenstelling tot voorgaande figuren, is er ditmaal sprake van een stijgende tendens. Schommelt het aandeel flexwerkers tussen 1996 en 2001 nog rond de 17\%, na 2001 vindt er een stijging plaats van dit aandeel tot 24\% in 2006.

\section{Figuur 7.9}

Aandeel flexwerkers in grafische industrie, 1996-2006

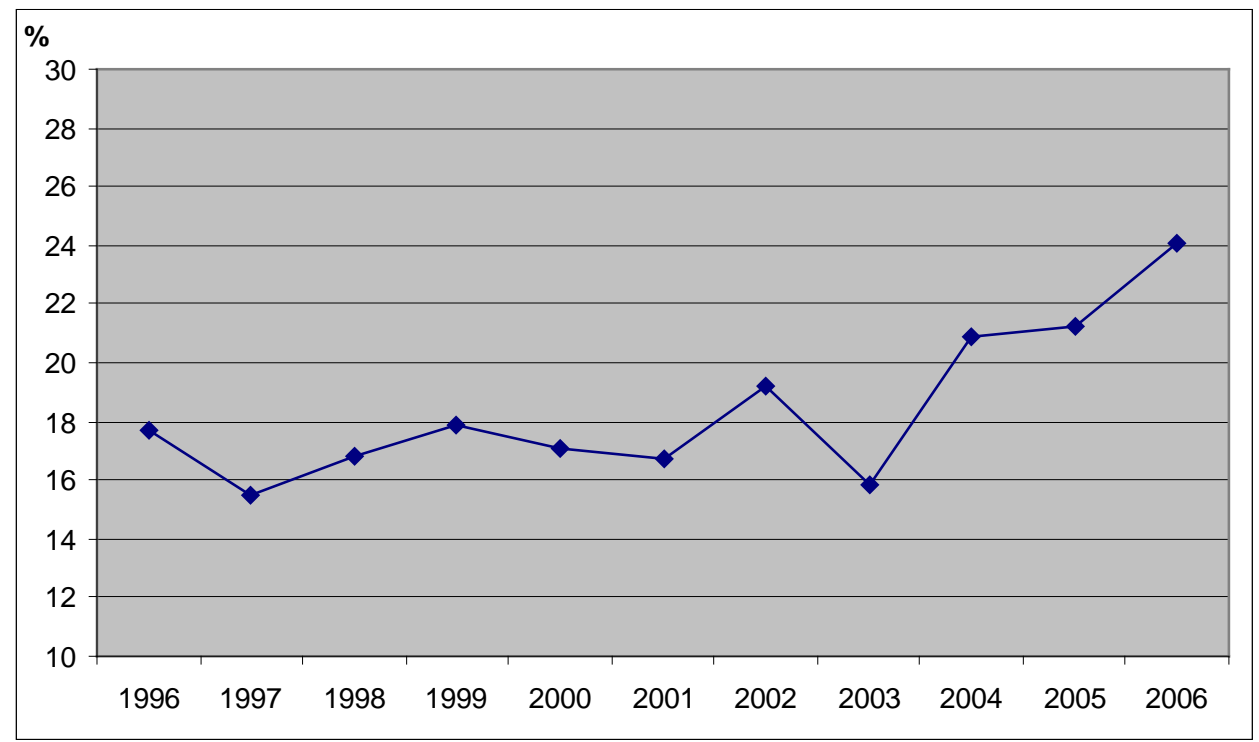

Bron: CBS (EBB)

Uit figuur 7.10, welke het aandeel flexwerkers in de handel en reparatie weergeeft, kan geconcludeerd worden dat dit aandeel licht toeneemt tot 1998, vervolgens geleidelijk afneemt en na 2003 weer iets sterker toeneemt.

\section{Figuur 7.10}

Aandeel flexwerkers in handel en reparatie, 1996-2006

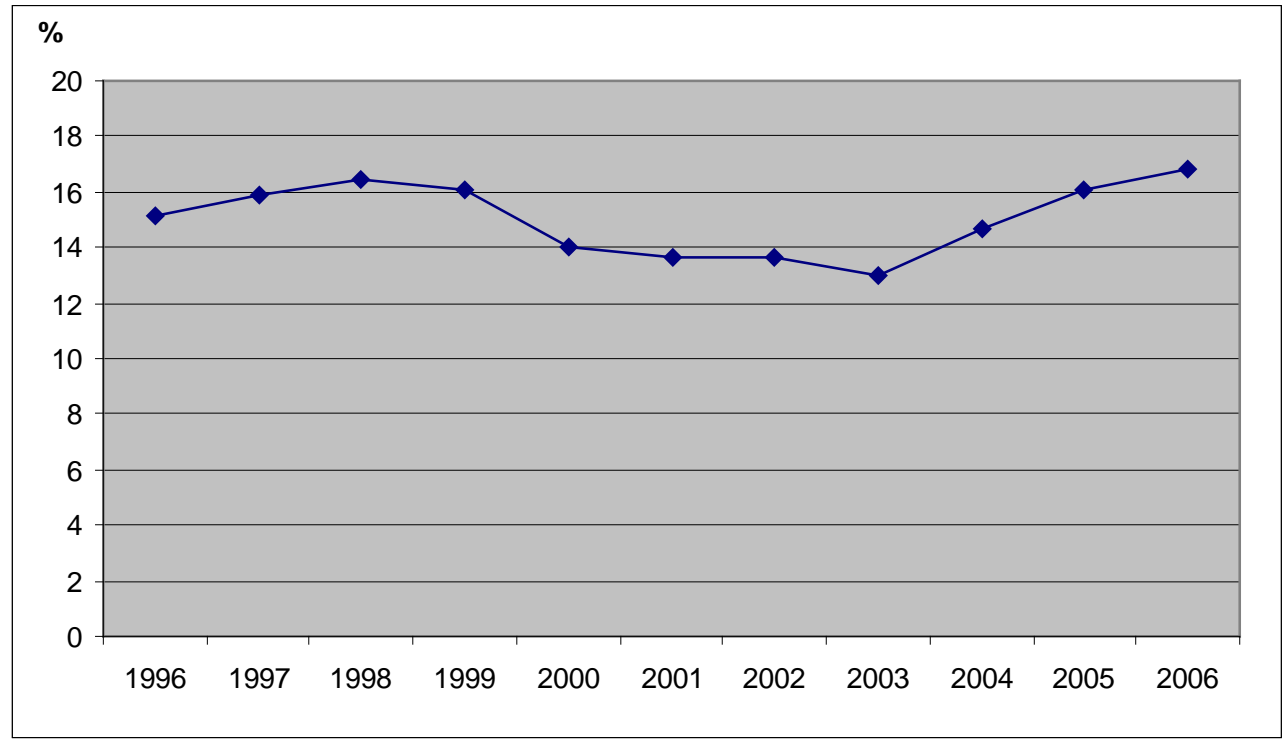

Bron: CBS (EBB) 


\section{Sectoren met meeste flexwerkers}

Een gemiddelde sector biedt werk aan meer dan 27.000 flexwerkers (1996-2006). De verschillen tussen de grootste sectoren en de kleinere sectoren zijn echter groot. Er zijn vier sectoren die er duidelijk bovenuit springen qua gemiddeld absoluut aantal flexwerkers. Deze worden afgebeeld in tabel 7.2. Handel en reparatie is de grootste sector, gevolgd door achtereenvolgens gezondheidszorg, horeca en zakelijke dienstverlening.

Tabel 7.2

Sectoren met grootste aantal flexwerkers, 1996-2006

\begin{tabular}{lc}
\hline & $\begin{array}{c}\text { Gemiddeld aantal } \\
\text { flexwerkers }\end{array}$ \\
\hline Handel en reparatie & 154.000 \\
Gezondheidszorg & 112.500 \\
Horeca & 93.500 \\
Zakelijke dienstverlening & 84.000 \\
\hline
\end{tabular}

Bron: CBS (EBB)

Evenals van de sectoren met relatief gezien de meeste flexwerkers, presenteren we in deze paragraaf ook de ontwikkeling van het aandeel flexwerkers van de absoluut gezien grootste sectoren (1996-2006). Aangezien de ontwikkeling van het aandeel flexwerkers in zowel de handel en reparatie als in de horeca reeds eerder besproken is, beperken we ons hier tot de gezondheidszorg en zakelijke dienstverlening.

In de gezondheidszorg is sprake van een licht dalende trendlijn voor de periode 1996-2006, zoals blijkt uit figuur 7.11. In 1998 was het aandeel flexwerkers in de gezondheidszorg het grootst $(14,8 \%)$.

\section{Figuur 7.11}

Aandeel flexwerkers in gezondheidszorg, 1996-2006

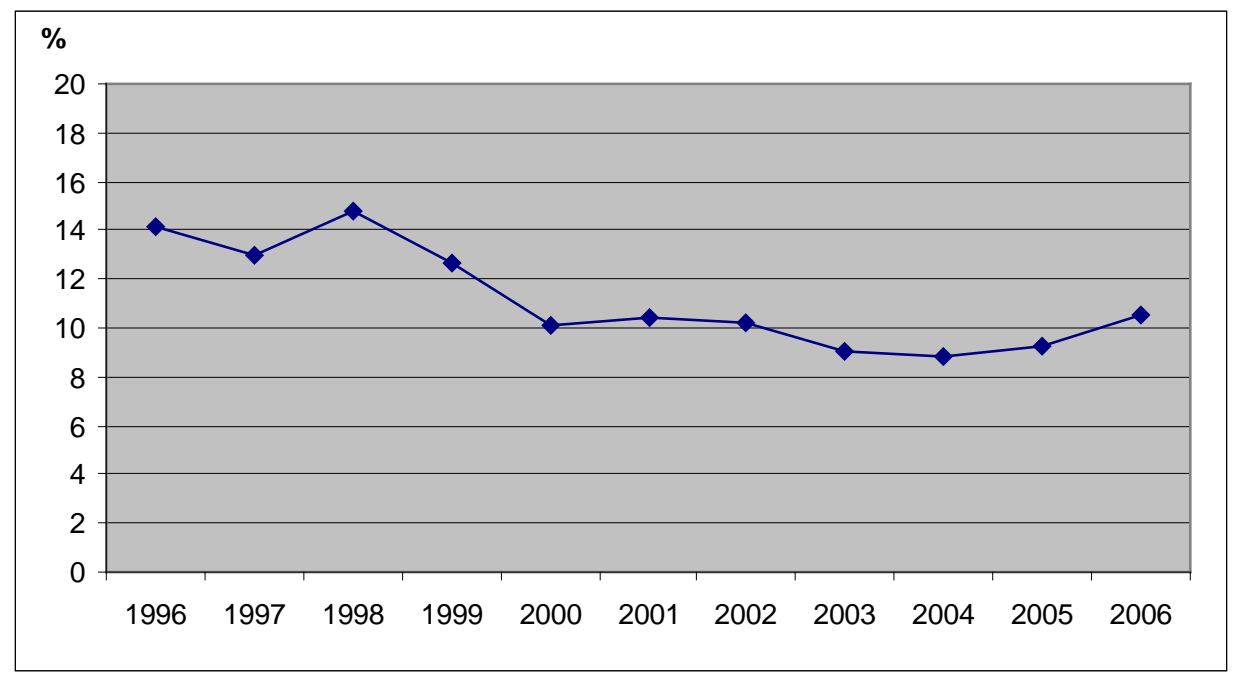

Bron: CBS (EBB) 
Het aandeel flexwerkers in de zakelijke dienstverlening neemt in de eerste jaren enigszins af, om vervolgens vrijwel constant te blijven tussen 1998 en 2003. Hierna is sprake van een lichte toename van het aandeel flexwerkers in deze sector.

\section{Figuur 7.12}

Aandeel flexwerkers in zakelijke dienstverlening, 1996-2006

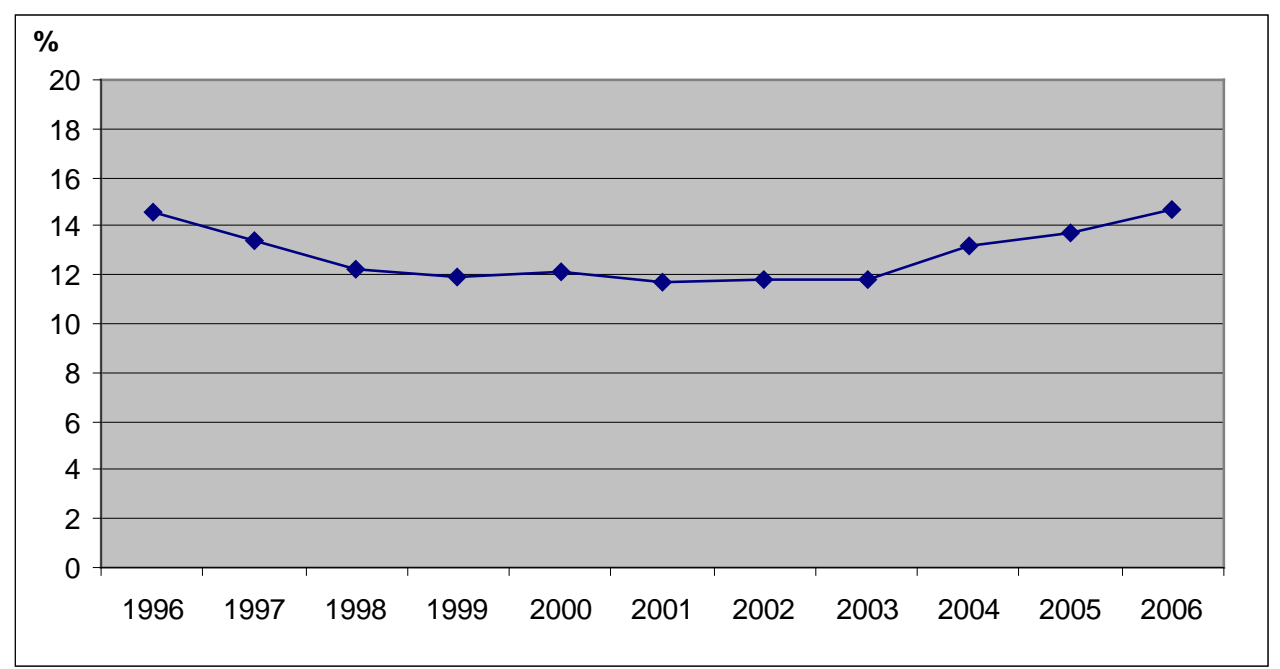

Bron: CBS (EBB)

\section{Verschillende verschijningsvormen van flexwerk per sector}

Naast het bekijken van het totale aandeel en totale aantal flexwerkers per sector is het daarnaast interessant om na te gaan of er fluctuaties waarneembaar zijn in de verschillende verschijningsvormen van flexwerk binnen de eerder besproken sectoren (1996-2006). We onderscheiden hierbij vijf verschillende soorten flexwerkers, te weten: uitzendkrachten, oproepkrachten, invalkrachten, mensen zonder vast diensverband en mensen zonder vaste uren. Hierna bespreken we de ontwikkeling van de verschillende verschijningvormen per sector per jaar voor alle sectoren waarvan de ontwikkeling van het totale flexaandeel reeds eerder besproken is.

\section{Horeca}

Zoals blijkt uit figuur 7.13 wordt veruit het grootste deel van het flexwerk binnen de horeca gedaan door oproepkrachten. In deze sector zijn er tussen 1996 enn 2006 geen grote fluctuaties in de populariteit van de verschillende verschijningsvormen van flexibele arbeid. 
Figuur 7.13

Aandeel verschijningsvormen flexwerk in horeca, 1996-2006

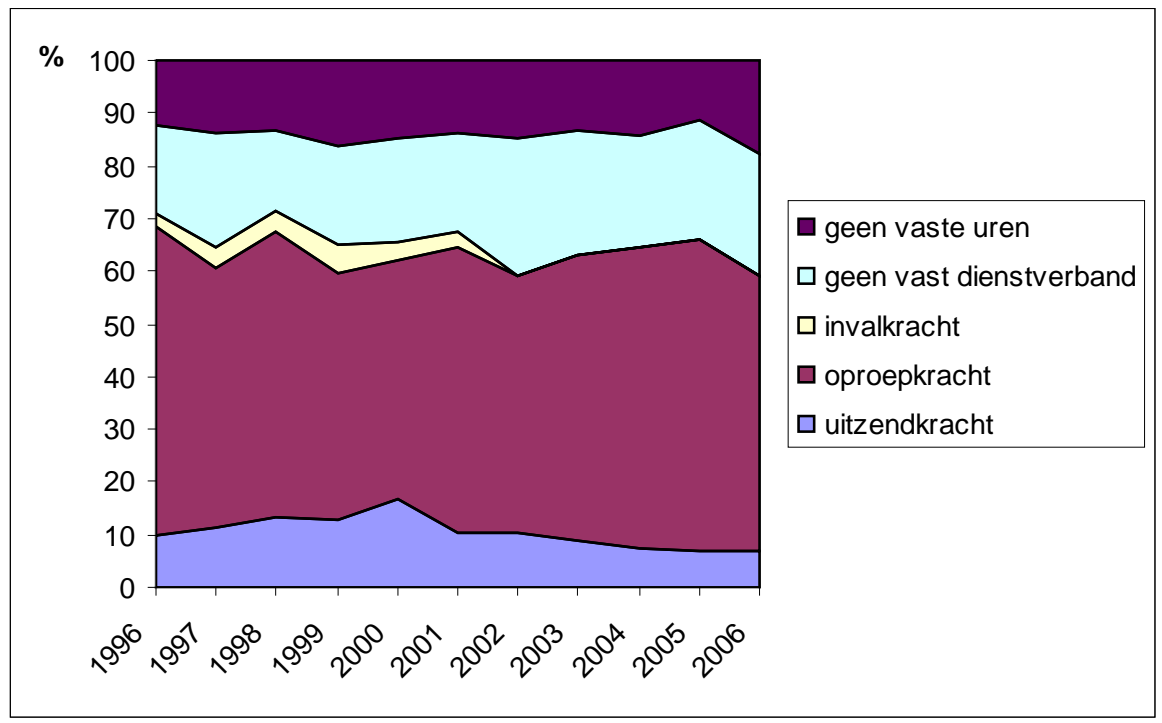

Bron: CBS (EBB)

Figuur 7.14 toont de ontwikkeling van het werkgelegenheidsaandeel van de sector horeca. Uit deze figuur kan geconcludeerd worden dat er sinds 1996 een kleine stijging is geweest van het aantal personen dat werkzaam is in de horeca ten opzichte van het aantal personen dat werkzaam is in alle sectoren samen. Gemiddeld zorgt de horeca voor 3,5\% van de totale werkgelegenheid.

Figuur 7.14

Werkgelegenheidsaandeel horeca, 1996-2006

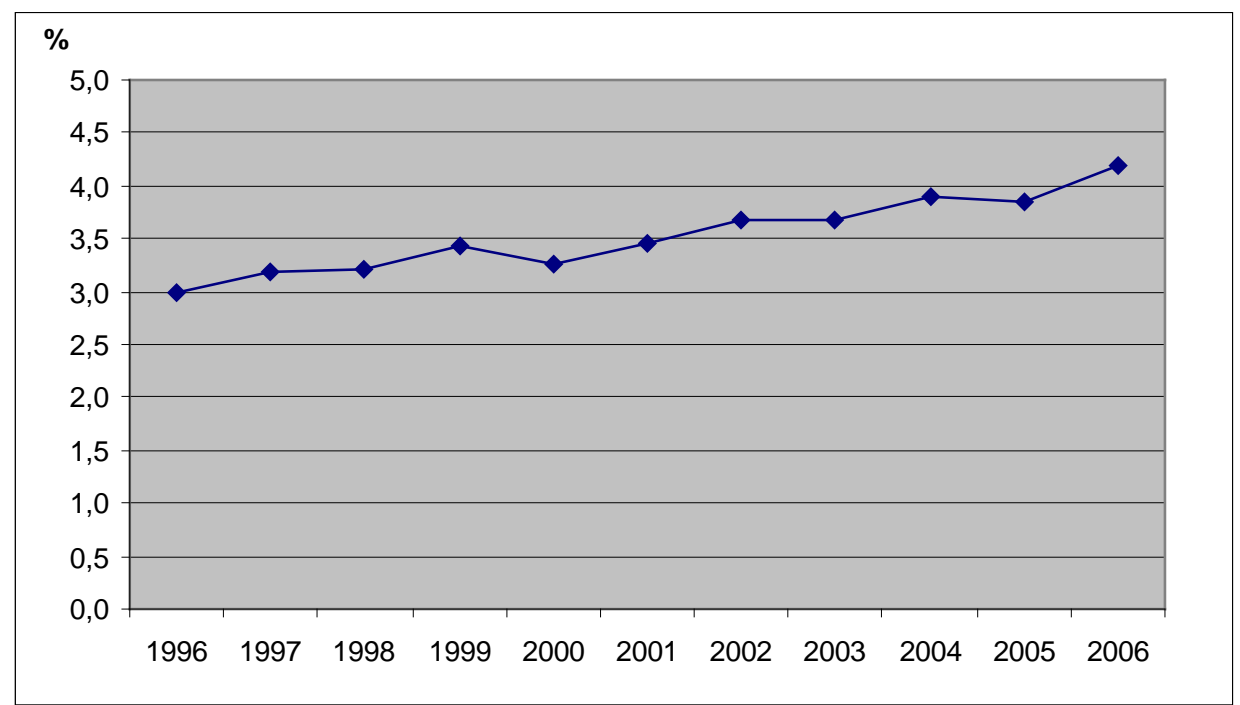

Bron: CBS (EBB)

\section{Landbouw en visserij}

Figuur 7.15 geeft de ontwikkeling weer van de verschillende verschijningsvormen van flexibele arbeid en laat zien dat in de landbouw en visserij voornamelijk gebruik maakt van 
oproepkrachten en mensen zonder vast dienstverband. Dit zijn veruit de meest voorkomende vormen van flexwerk in deze sector gedurende de hele periode.

Figuur 7.15

Aandeel verschijningsvormen flexwerk in landbouw en visserij, 1996-2006

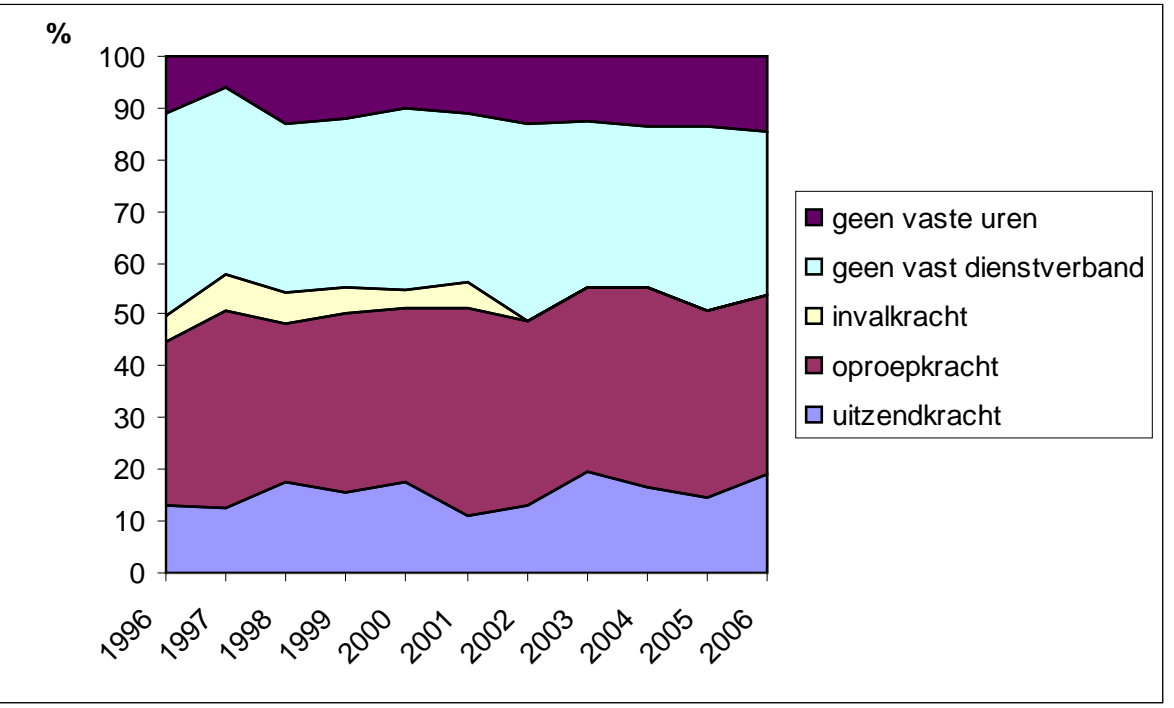

Bron: CBS (EBB)

Het werkgelegenheidsaandeel van deze sector schommelt tussen 1996 en 2006 rond de $1,7 \%$ van de totale werkgelegenheid, waarmee het dus een kleine sector betreft.

Figuur 7.16

Werkgelegenheidsaandeel landbouw en visserij, 1996-2006

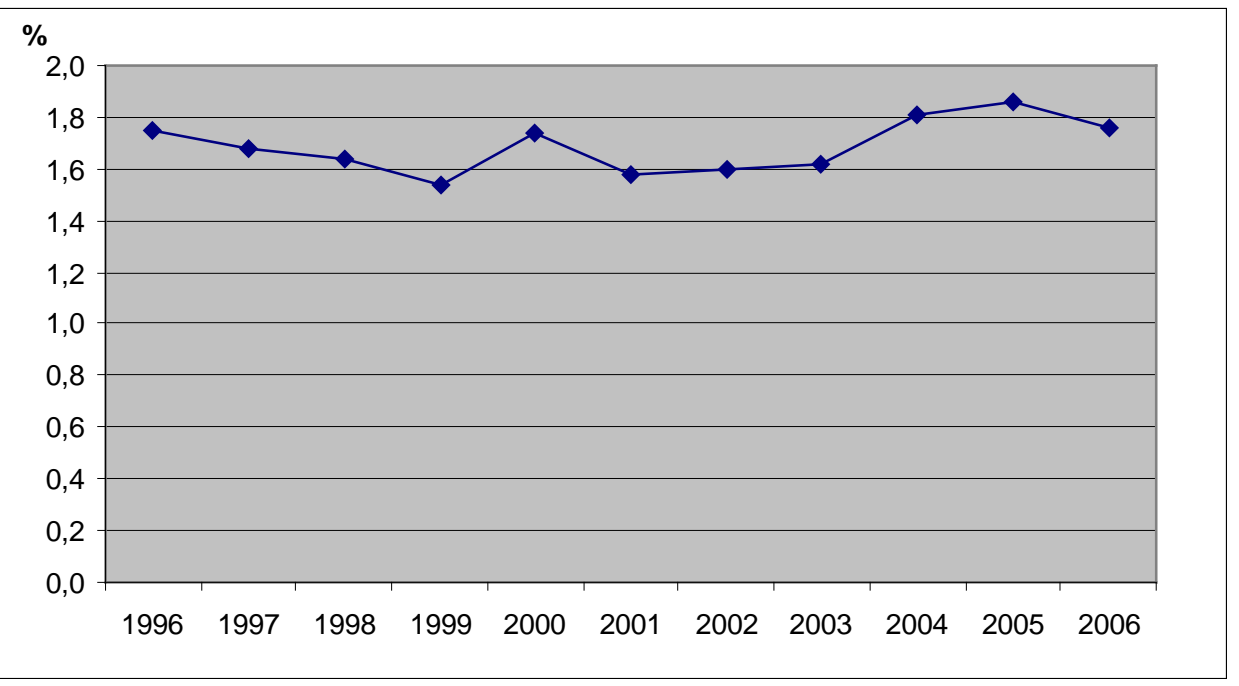

\section{Overige commerciële dienstverlening}

Uit figuur 7.17 blijkt dat het aandeel van de verschillende verschijningsvormen binnen de 'overige commerciële dienstverlening' behoorlijk fluctueert gedurende de periode 1996-2006. Werkte er in de eerste jaren nog meer dan 60\% van de flexibele arbeidskrachten zonder vast dienstverband, in 2006 was dit nog maar 20\%. In deze sector wordt daarentegen 
steeds vaker gebruik gemaakt van oproepkrachten, uitzendkrachten en mensen zonder vaste uren.

Figuur 7.17

Aandeel verschijningsvormen flexwerk in overige commerciële dienstverlening, 1996-2006

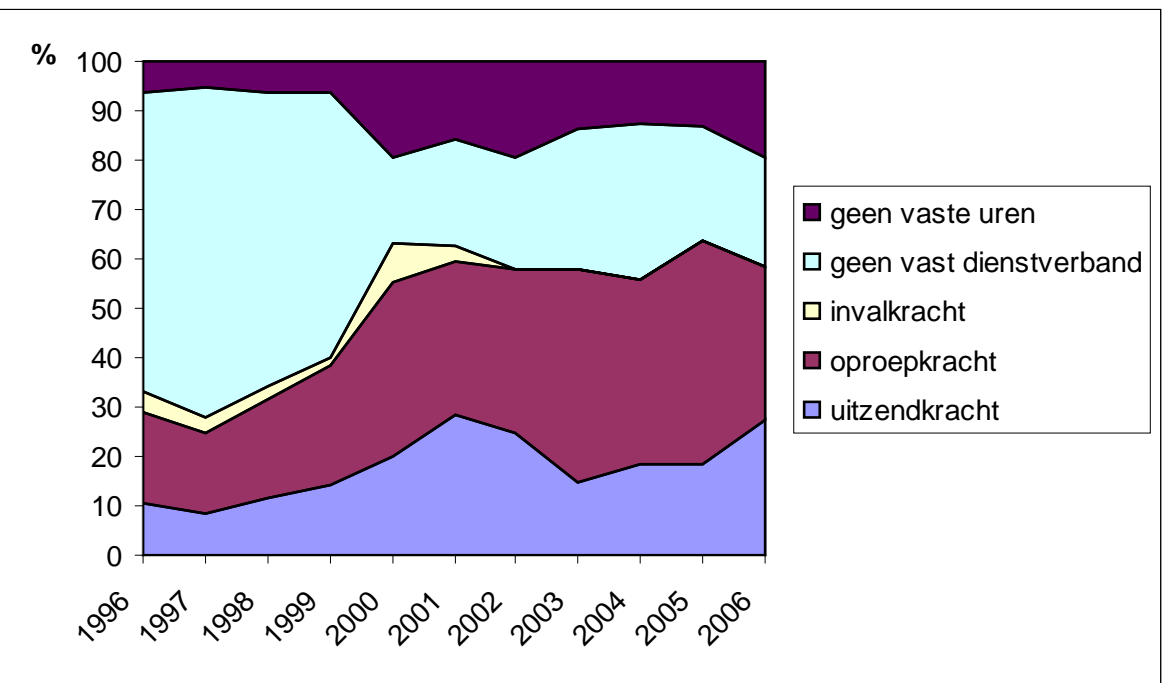

Bron: CBS (EBB)

Figuur 7.18 laat echter zien dat het ook hier weer om een relatief kleine sector gaat op het gebied van werkgelegenheid.

\section{Figuur 7.18}

Werkgelegenheidsaandeel overige commerciële dienstverlening, 1996-2006

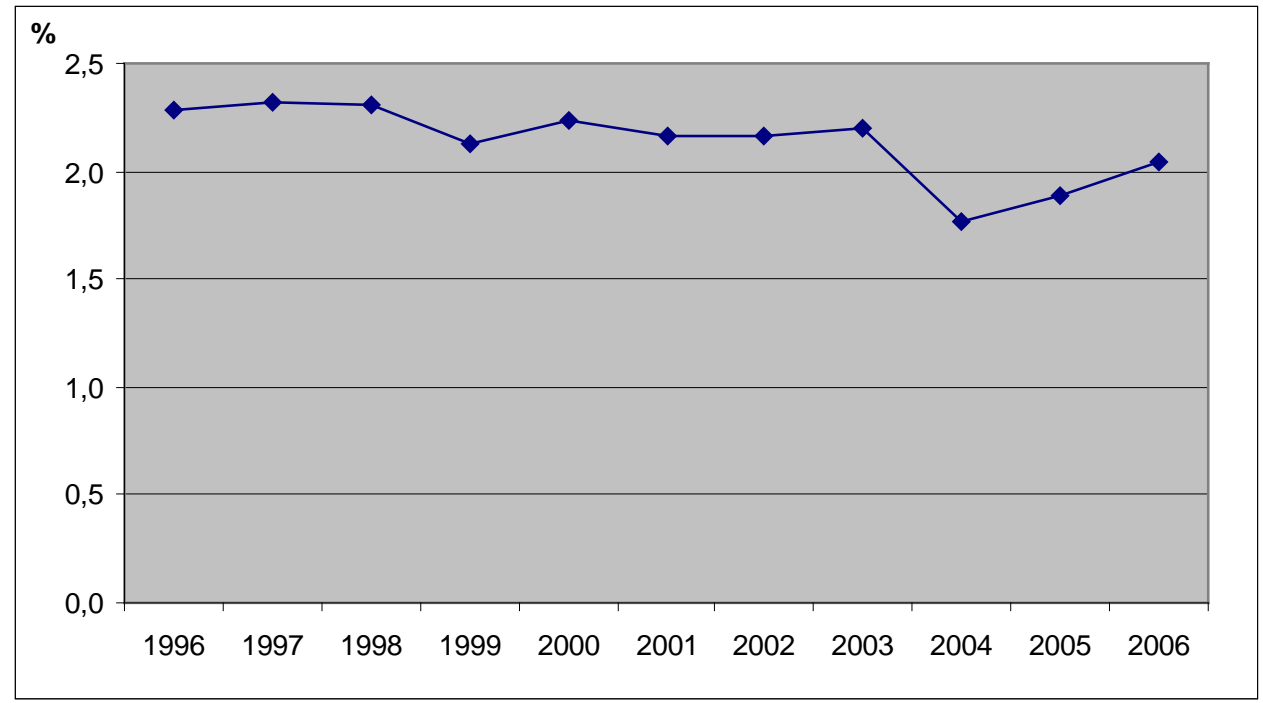

Bron: CBS (EBB)

\section{Vlees- en visverwerking}

Wanneer we kijken naar de verschillende flexwerk verschijningsvormen binnen de zes sectoren met het grootste aandeel flexwerk is er één sector met een heel groot aandeel uitzendkrachten, te weten de vlees- en visverwerking. Hierin heeft gemiddeld meer dan 63\% 
van de flexwerkers een contract op uitzendbasis. In de andere sectoren met een relatief groot aandeel flexibele arbeid, speelt uitzendwerk een aanzienlijk minder grote rol als in de vlees- en visverwerking. Wat wel opvalt, is dat binnen het uitzendwerk in deze sector een dalende tendens waarneembaar is van bijna $70 \%$ in 1996 naar een kleine $60 \%$ in 2006.

\section{Figuur 7.19}

Aandeel verschijningsvormen flexwerk in vlees- en visverwerking, 1996-2006

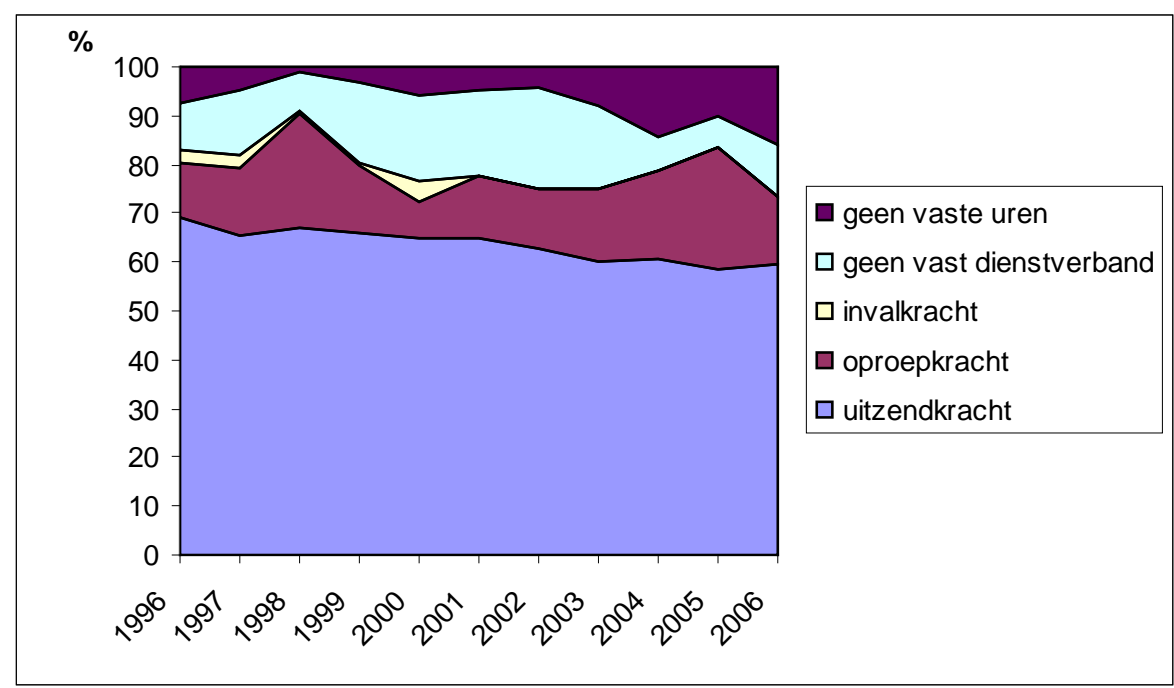

Bron: CBS (EBB)

Uit figuur 7.20 kan geconcludeerd worden dat het hier echter een zeer kleine sector betreft, die nog geen procent van de totale werkgelegenheid levert. Gedurende de periode 19962006 schommelt het werkgelegenheidsaandeel van deze sector tussen de 0,4\% en 0,7\%.

\section{Figuur 7.20}

Werkgelegenheidsaandeel vlees- en visverwerking, 1996-2006

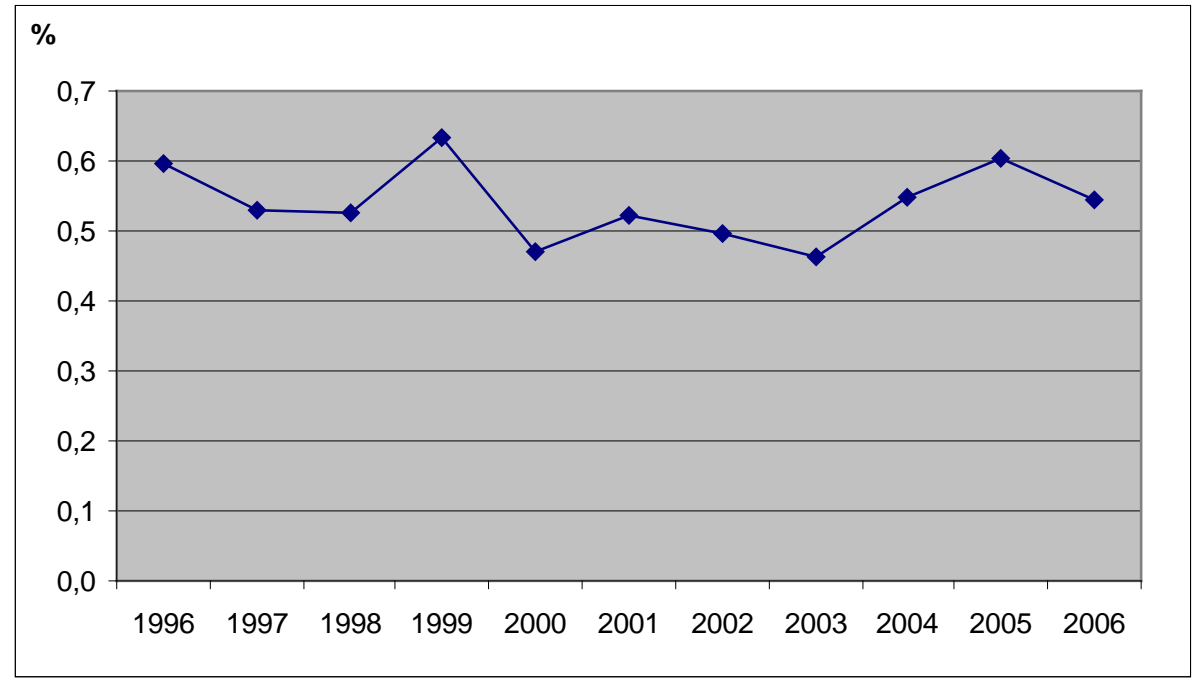

Bron: CBS (EBB) 


\section{Grafische industrie}

In de grafische industrie maken werkgevers vooral gebruik van werknemers zonder vast dienstverband, zoals weergegeven in figuur 7.21. Daarnaast is er een behoorlijk aantal personen dat zonder vaste uren werkt. Het aandeel uitzendkrachten schommelde tussen 1996 en 2002 rond de 20\%, terwijl dit aandeel na 2002 afnam tot iets meer dan 10\%.

Figuur 7.21

Aandeel verschijningsvormen flexwerk in grafische industrie, 1996-2006

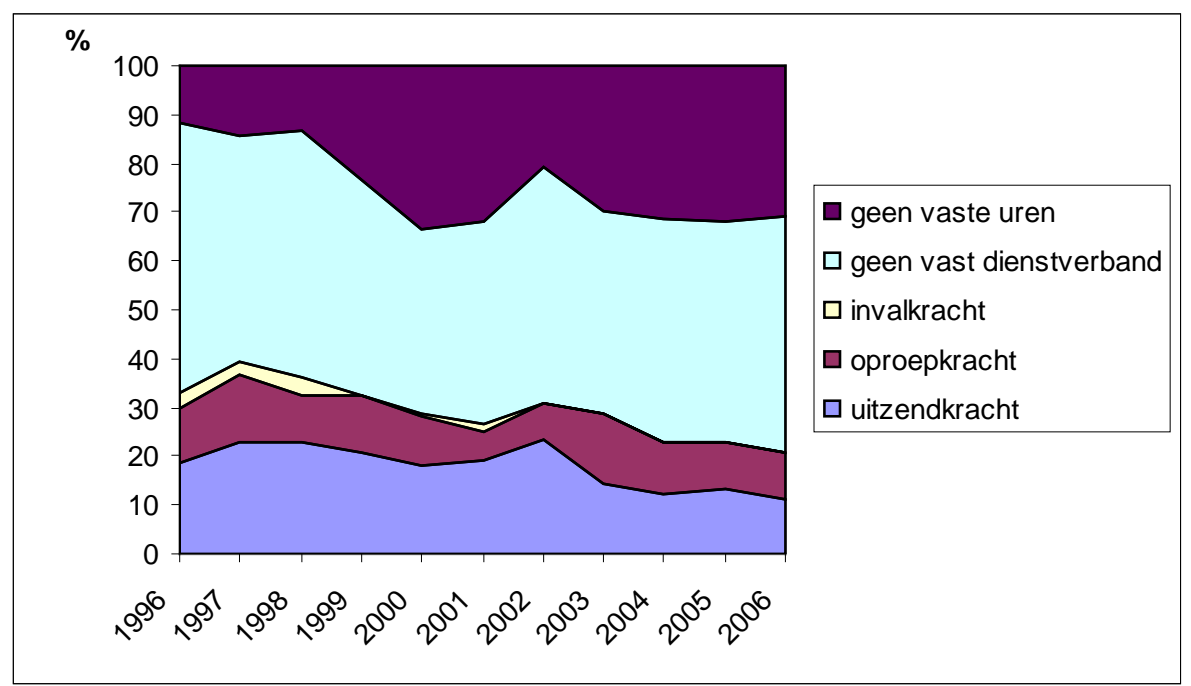

Bron: CBS (EBB)

Kijken we naar de werkgelegenheid van de grafische sector ten opzichte van de totale werkgelegenheid gedurende de laatste jaren, dan laat deze een licht dalende tendens zien van zo'n 0,4 procentpunt.

\section{Figuur 7.22}

Werkgelegenheidsaandeel grafische industrie, 1996-2006

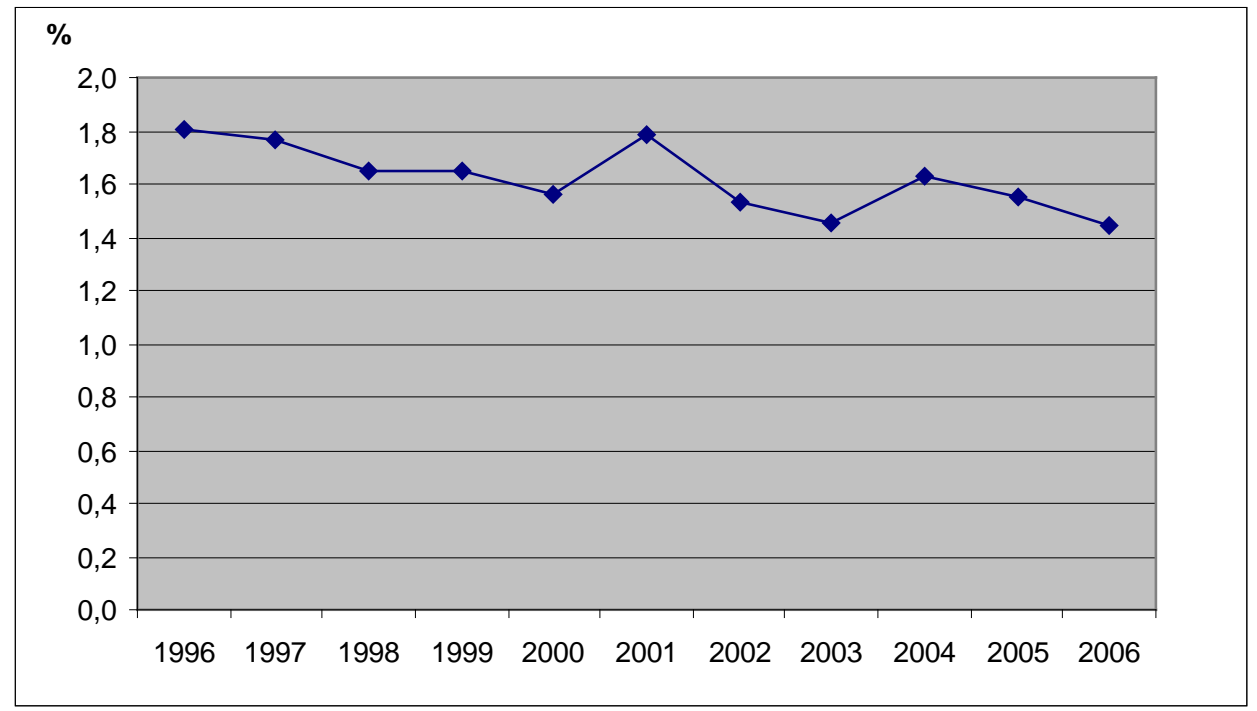

Bron: CBS (EBB) 


\section{Handel en reparatie}

Binnen de sector handel en reparatie worden met name oproepkrachten ingeschakeld als het om flexibele arbeid gaat. Dit wordt weergegeven in figuur 7.23. Vanaf 2001 werken ook veel mensen zonder vast dienstverband. Tussen 1996 en 2006 heeft gemiddeld 13,8\% een uitzendcontract in deze sector. In het algemeen laat deze figuur weinig fluctuaties zien in de populariteit van de verschillende verschijningsvormen.

\section{Figuur 7.23}

Aandeel verschijningsvormen flexwerk in handel en reparatie, 1996-2006

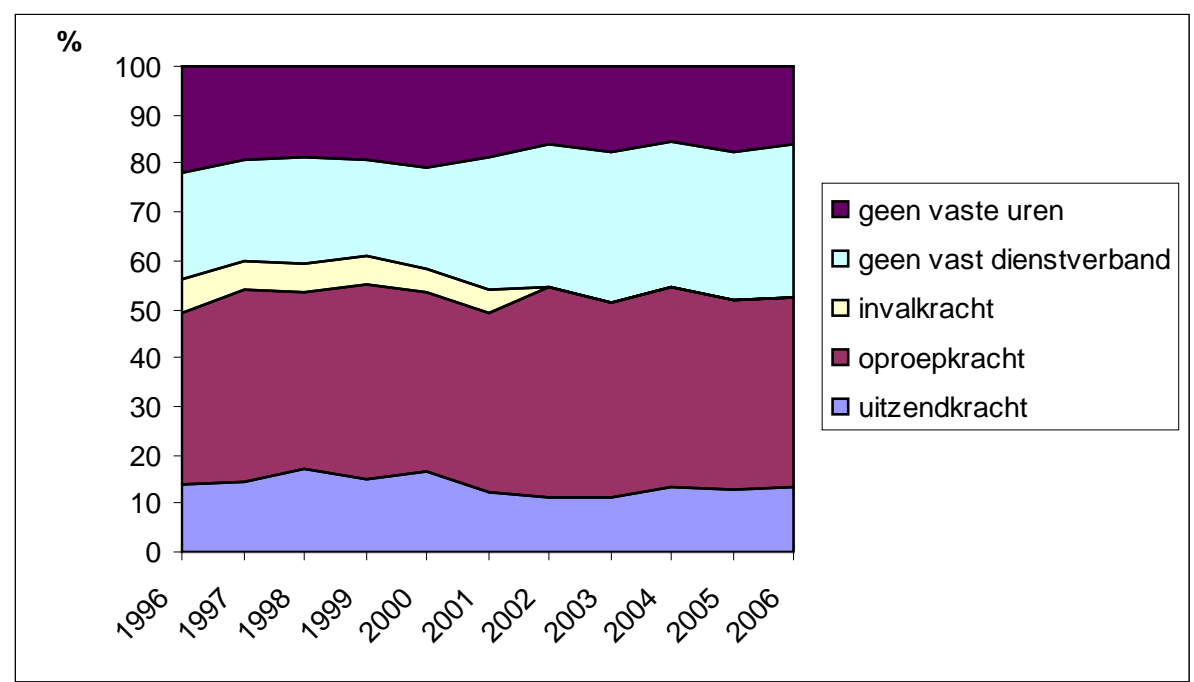

Bron: CBS (EBB)

Het werkgelegenheidsaandeel van de sector handel en reparatie is groot in vergelijking met de eerder besproken sectoren zoals blijkt uit figuur 7.24. Sinds 2003 is het werkgelegenheidsaandeel van deze sector wel iets gedaald.

\section{Figuur 7.24}

Werkgelegenheidsaandeel handel en reparatie, 1996-2006

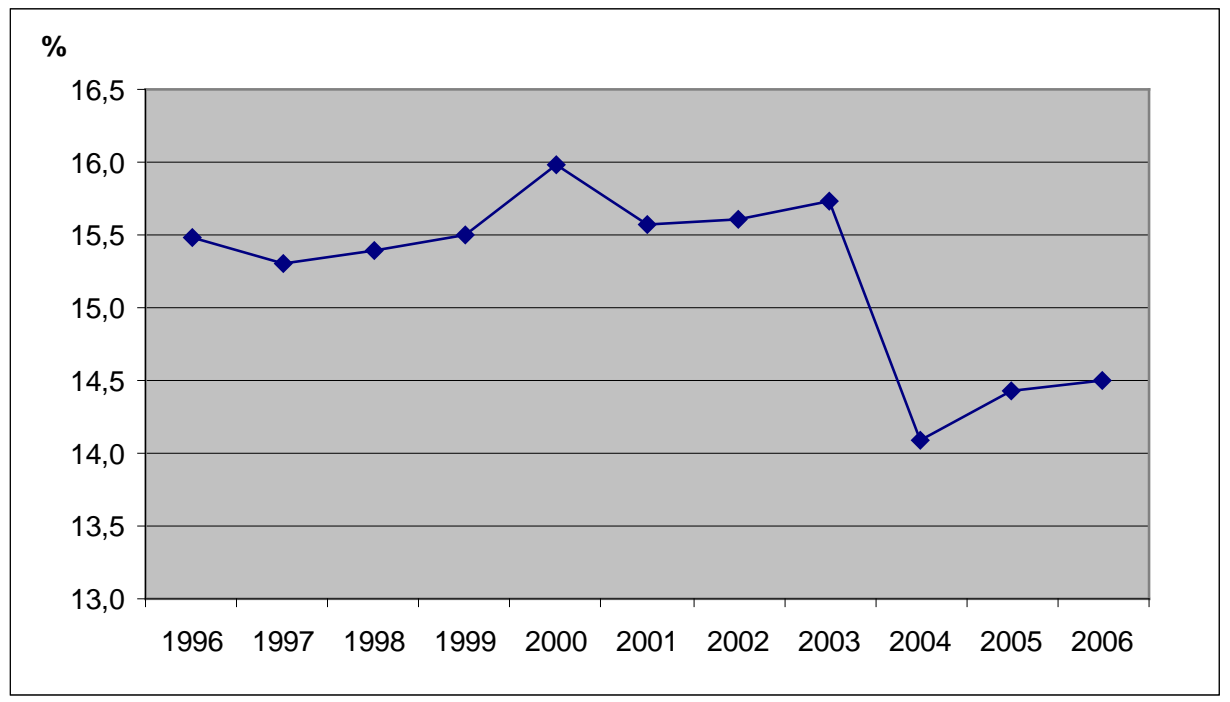

Bron: CBS (EBB) 


\section{Gezondheidszorg}

De gezondheidszorg maakt voornamelijk gebruik van oproepkrachten. Dit wordt weergegeven in figuur 7.25. Ook is er een stijging zichtbaar in het aantal werknemers dat werkzaam is zonder vast dienstverband. Het aandeel uitzendkrachten schommelt tussen de $7 \%$ en $16 \%$ van alle flexwerkers in deze sector. Ten slotte is er in de gezondheidszorg in 2006 een stijging geweest in het aantal personen dat werkt zonder vaste uren.

\section{Figuur 7.25}

Aandeel verschijningsvormen flexwerk in gezondheidszorg, 1996-2006

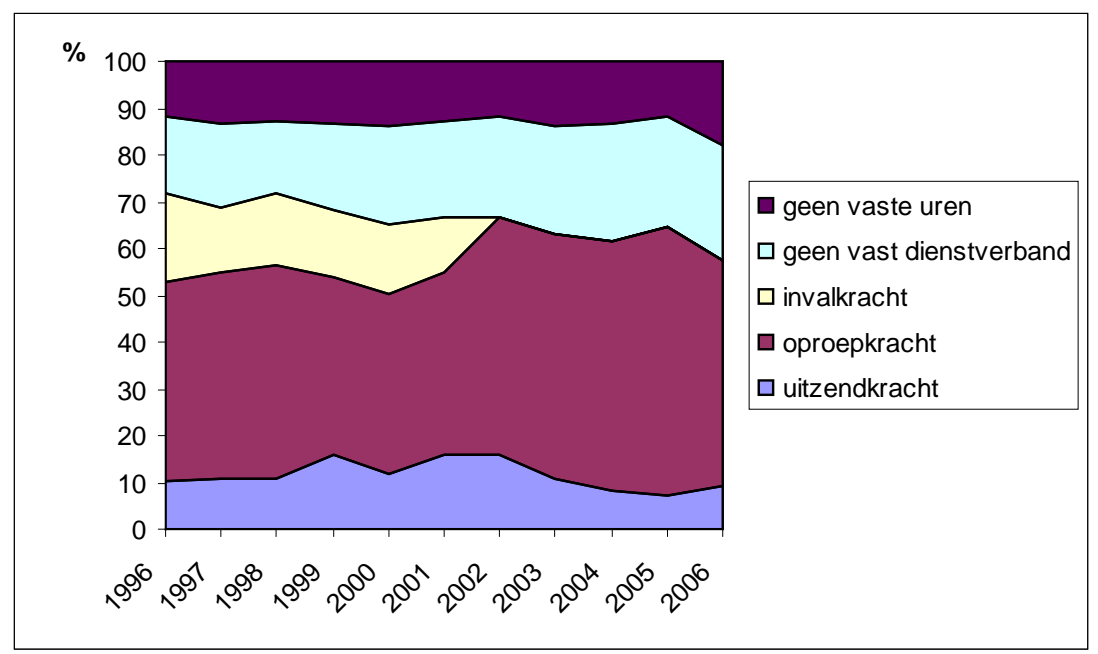

Bron: CBS (EBB)

Droeg de gezondheidszorg aan het begin van de onderzoeksperiode bij aan zo'n 14\% van de totale werkgelegenheid, vanaf 1999 laat figuur 7.26 een stijgende tendens zien. Het werkgelegenheidsaandeel van de gezondheidszorg bedraagt in 2006 dan ook meer dan $16,5 \%$.

\section{Figuur 7.26}

Werkgelegenheidsaandeel gezondheidszorg, 1996-2006

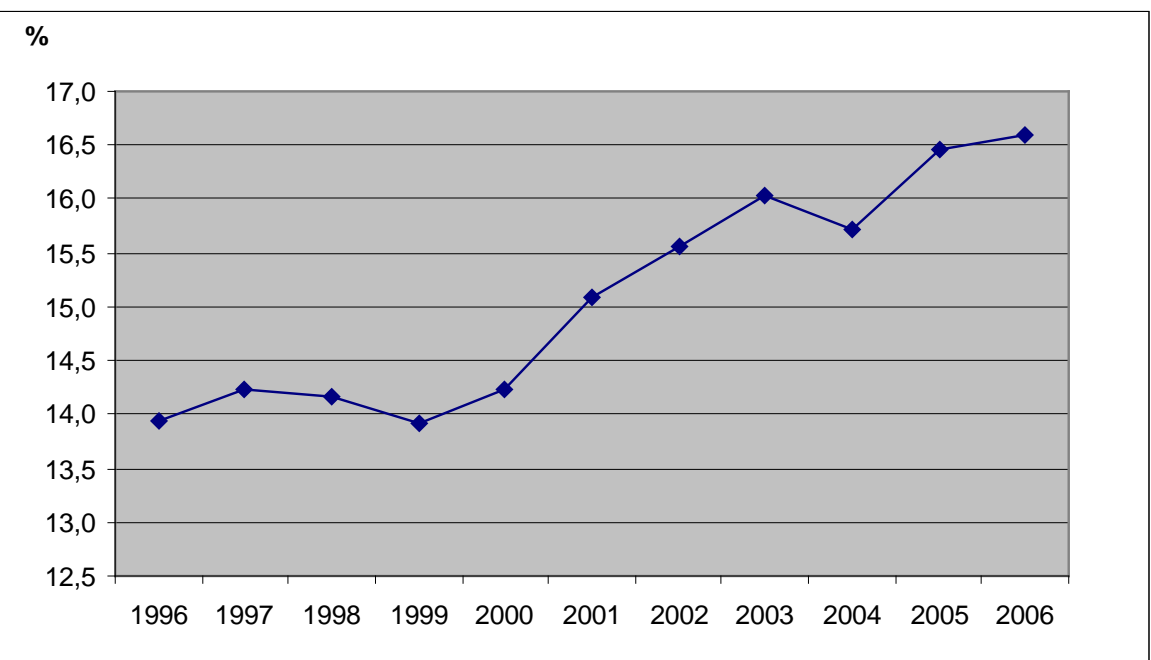

Bron: CBS (EBB) 


\section{Zakelijke dienstverlening}

Met betrekking tot de zakelijke dienstverlening is het opvallend dat het gemiddelde aandeel flexwerk in deze sector even groot is als het gemiddelde aandeel flexwerk in alle sectoren samen (12,8\%). In de zakelijke dienstverlening zijn verhoudingsgewijs veel uitzendkrachten werkzaam. Figuur 7.27 geeft weer dat het aandeel uitzendkrachten in de zakelijke dienstverlening gestegen is vanaf 2002. Het aandeel oproepkrachten neemt daarentegen af. Het relatieve aantal personen zonder vast dienstverband fluctueert nogal, evenals het relatieve aantal personen zonder vaste uren.

\section{Figuur 7.27}

Aandeel verschijningsvormen flexwerk in zakelijke dienstverlening, 1996-2006

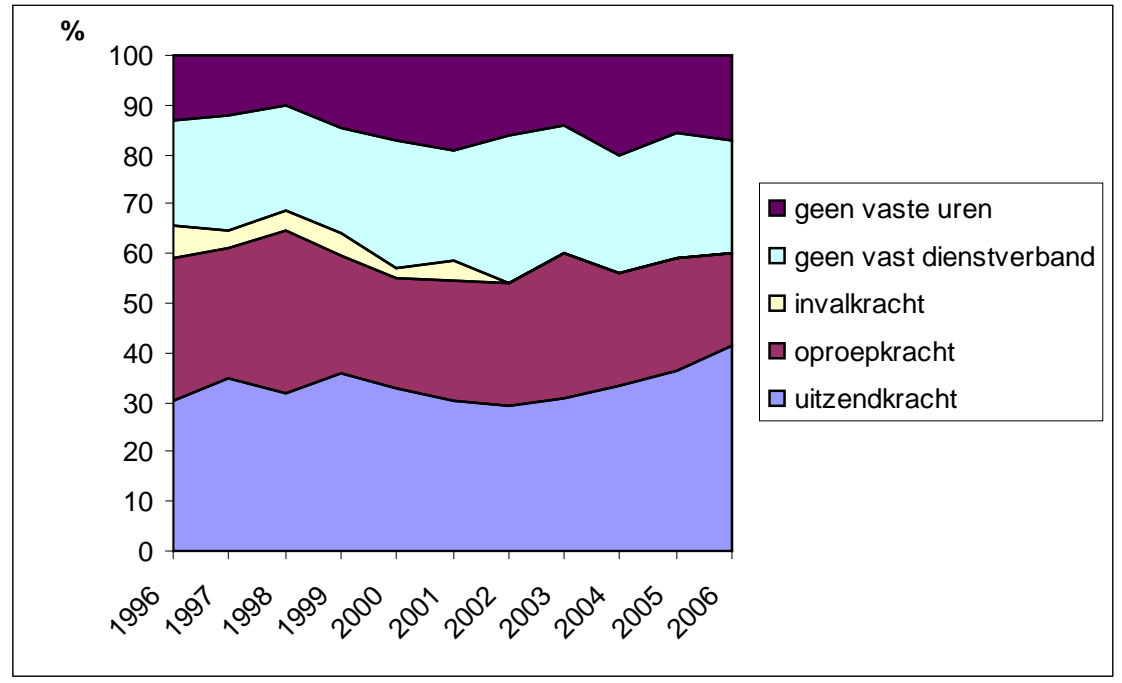

Bron: CBS (EBB)

De sector zakelijke dienstverlening is verder behoorlijk omvangrijk en draagt bij aan om en nabij de $10 \%$ van de totale werkgelegenheid, zoals weergegeven in figuur 7.28.

\section{Figuur 7.28}

Werkgelegenheidsaandeel zakelijke dienstverlening, 1996-2006

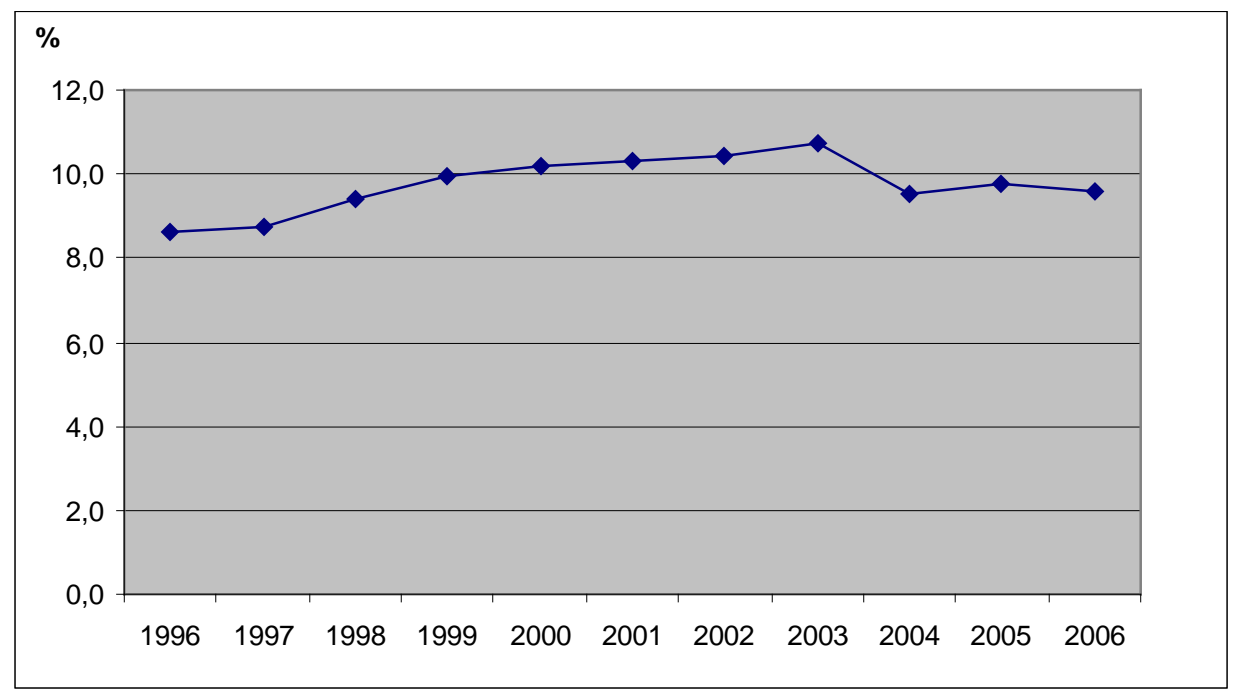

Bron: CBS (EBB) 


\subsection{Ontwikkeling flexwerk naar opleiding}

\section{Aandeel flexwerkers onder schoolverlaters per opleidingsniveau}

Uit figuur 7.29 kan geconcludeerd worden dat er verhoudingsgewijs veel flexwerk door schoolverlaters gedaan wordt, ongeacht het niveau van de hoogst genoten opleiding. De data zijn afkomstig uit het Schoolverlaters Informatie Systeem (SIS) van ROA. Dit onderzoek is gericht op recent afgestudeerden die benaderd worden ongeveer 1,5 jaar na afstuderen. Het grootste aandeel van het flexwerk wordt gedaan door schoolverlaters met een HAVO- of WWO-opleiding. Onder schoolverlaters hebben MBO'ers relatief gezien het minst vaak een flexibel arbeidscontract. Verder is het opvallend te noemen dat veel schoolverlaters met een WO-achtergrond een flexibele contractvorm hebben, zelfs tussen de 40 en 50\% gedurende de hele periode.

\section{Figuur 7.29}

Aandeel werknemers onder schoolverlaters met een flexibel contract per opleidingsniveau, 1996-2006

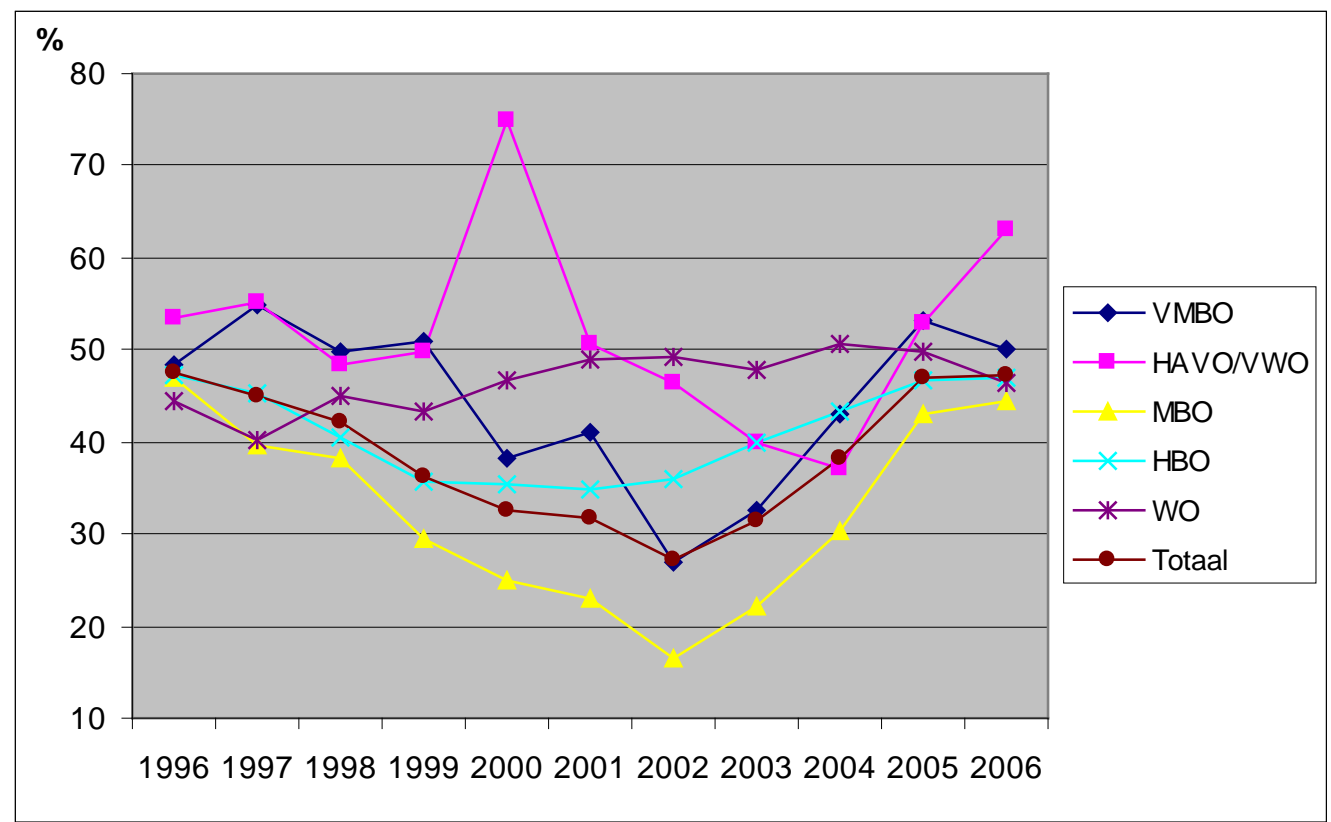

Bron: ROA (SIS)

Aandeel flexwerkers onder werknemers per opleidingsniveau

Uit figuur 7.30 blijkt, in tegenstelling tot de hiervoor besproken data over schoolverlaters, dat het aandeel flexwerk afneemt wanneer men een vervolgopleiding gevolgd heeft. Hoogopgeleiden maken de meeste kans op een vaste baan. Van de arbeidskrachten met een universitaire opleiding heeft slechts 5,9\% een flexibel arbeidscontract. Ook personen met een HBO-diploma krijgen doorgaans een vast contract. Van alle personen met een HBO-achtergrond heeft gemiddeld slechts $7,8 \%$ een flexibel contract. Ook het flexaandeel van afgestudeerde MBO'ers ligt gemiddeld gezien nog altijd onder de $10 \%$ in de periode 1996-2006. 


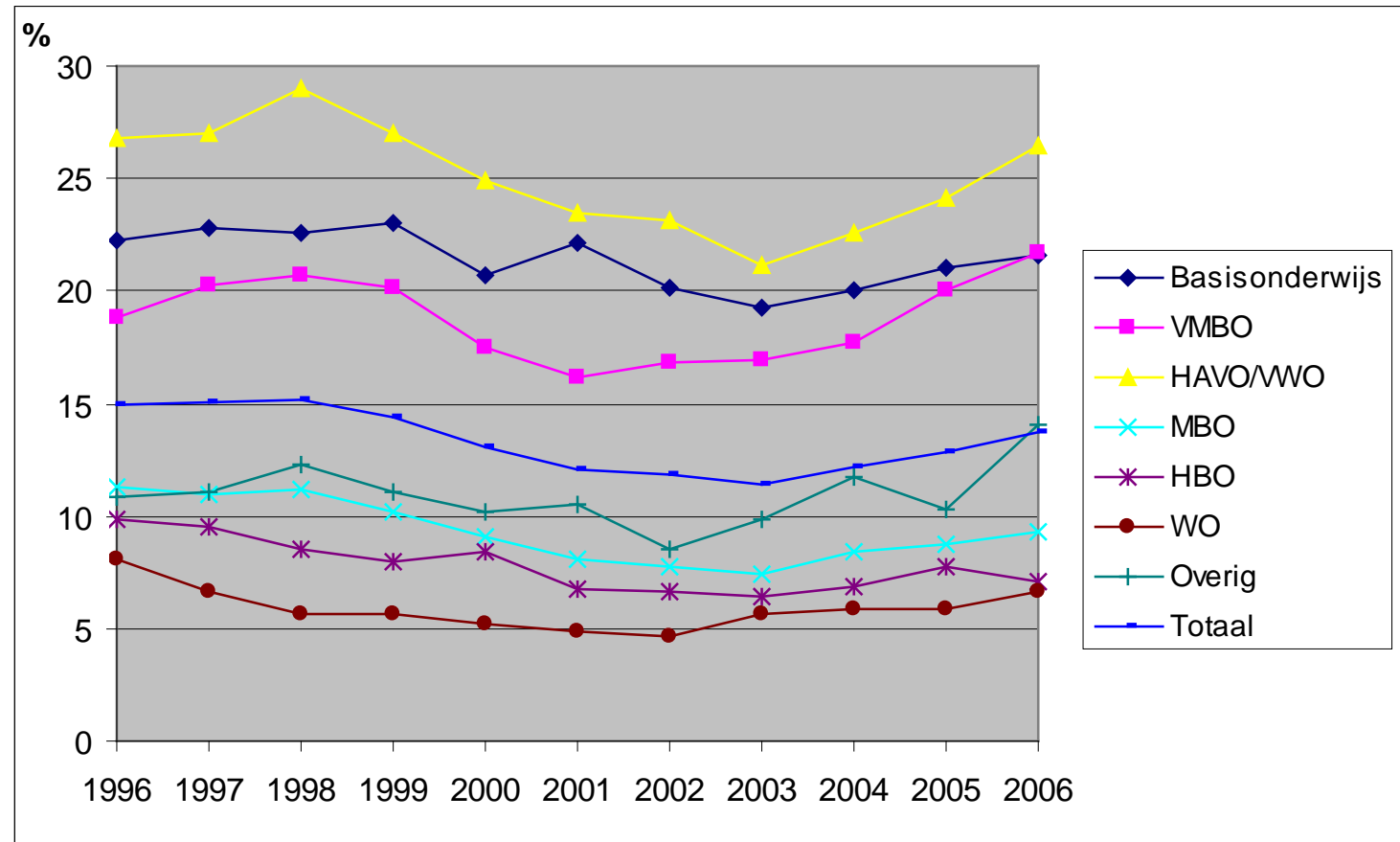

Bron: CBS (EBB)

Hier tegenover staan hoge percentages flexibele arbeid onder personen met basisonderwijs, VMBO of HAVO/MWO als hoogst genoten opleiding. Laatstgenoemde groep heeft in de praktijk relatief het vaakst een flexibel contract. Niet minder dan 1 op de 4 personen met een HAVO- of VWO-opleiding als hoogst genoten opleiding heeft gemiddeld namelijk een flexibel contract in de periode 1996-2006. Personen die enkel basisonderwijs genoten hebben, evenals personen met een VMBO-diploma, hebben doorgaans ook een relatief grote kans om een flexibel contract te krijgen. Het gemiddeld aandeel flexwerkers binnen deze groepen bedraagt respectievelijk $21,4 \%$ en $18,8 \%$. Het aandeel flexwerkers binnen de groep personen behorend tot 'overig onderwijs' bevindt zich op een niveau tussen dat van de laagopgeleiden en de groep die doorstudeert in.

In het algemeen kan dus uit figuur 7.30 geconcludeerd worden dat personen die een vast contract willen, er doorgaans goed aan doen om een vervolgstudie af te ronden na het verlaten van de middelbare school.

\subsection{Ontwikkeling flexwerk naar beroep}

In dit hoofdstuk wordt de ontwikkeling van het aandeel flexwerkers voor de verschillende beroepsklassen weergegeven in de periode 1996-2006. Er worden elf beroepsklassen onderscheiden: pedagogische beroepen, technische en industrieberoepen, medische en paramedische beroepen, sociaal-culturele beroepen, orde- en veiligheidsberoepen, 
economisch-administratieve beroepen, informaticaberoepen, culturele beroepen, agrarische beroepen, verzorgende en dienstverlenende beroepen en tot slot de transportberoepen.

Figuur 7.31 geeft het gemiddeld aandeel flexwerkers weer voor het totaal van deze beroepsklassen per jaar. Dit om de ontwikkeling van het aandeel flexwerk van elk van de twaalf afzonderlijke beroepsklassen te kunnen vergelijken met de ontwikkeling van het aandeel flexwerk van het totaal aantal beroepsklassen. Alle beroepsklassen samen laten een gemiddeld flexaandeel van $13,4 \%$ zien. $\mathrm{Na} 1998$ is een daling in het aandeel flexwerkers waarneembaar. In 2003 bereikt deze daling het laagste punt, waarna het aandeel flexwerkers gestaag stijgt tot 2006.

\section{Figuur 7.31}

Aandeel flexwerk in totaal van beroepsklassen, 1996-2006

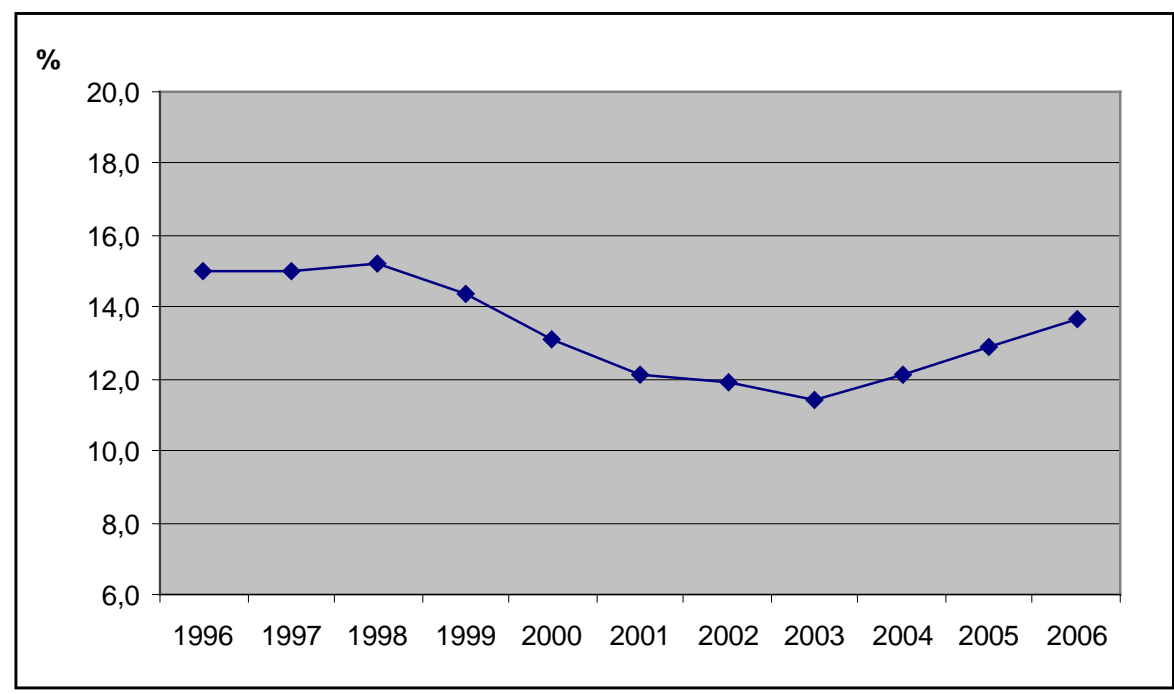

Bron: CBS (EBB)

Hierna bespreken we de ontwikkeling van het aandeel flexwerkers per beroepsklasse voor de periode 1996-2006. Allereerst wordt dit besproken voor de pedagogische beroepen. Vergeleken met het gemiddelde van het totaal aantal beroepen $(13,4 \%)$ werken er in de pedagogische beroepen gemiddeld relatief minder flexwerkers (7,9\%). Over de hele periode is er in deze beroepsklasse een licht dalende tendens waarneembaar in het aandeel flexwerkers. 
Figuur 7.32

Aandeel flexwerk in pedagogische beroepen, 1996-2006

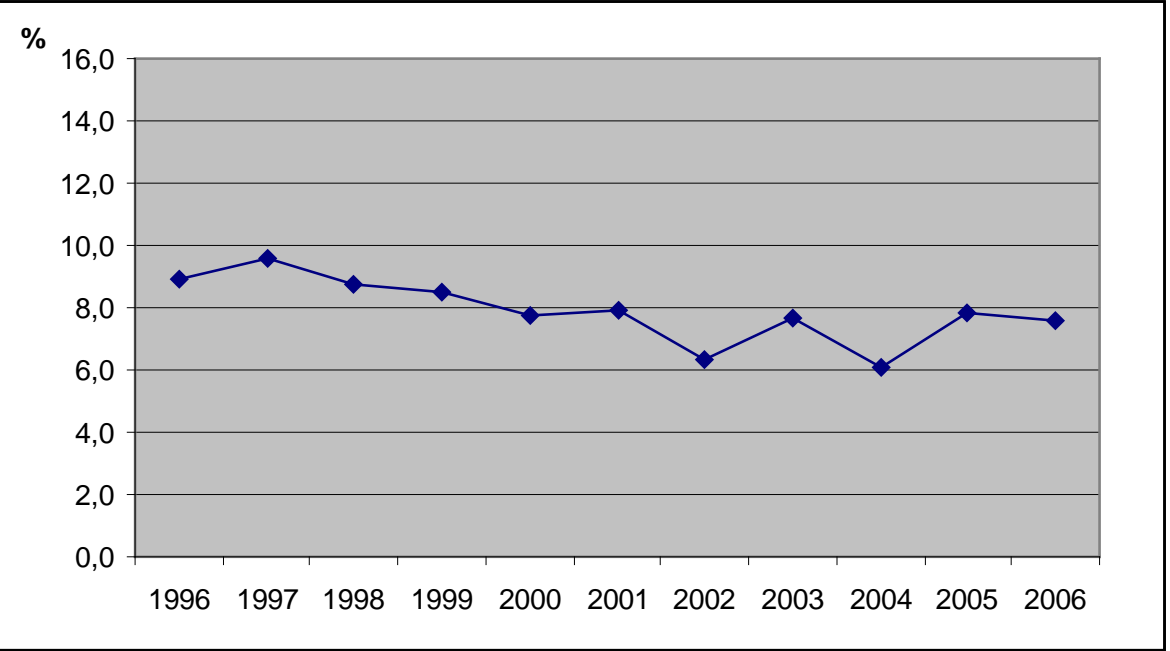

Bron: CBS (EBB)

Voor de technische en industrieberoepen geldt min of meer hetzelfde verhaal als voor de pedagogische beroepen. Het gemiddelde flexaandeel in de technische en industrieberoepen is $8,4 \%$. Dit is min of meer gelijk aan hetzelfde aandeel in de pedagogische beroepen. In tegenstelling tot de pedagogische beroepen, loopt het aandeel flexwerkers in de technische en industrieberoepen in lijn met de ontwikkeling van het aandeel van de totale beroepsklassen.

\section{Figuur 7.33}

Aandeel flexwerk in technische en industrieberoepen, 1996-2006

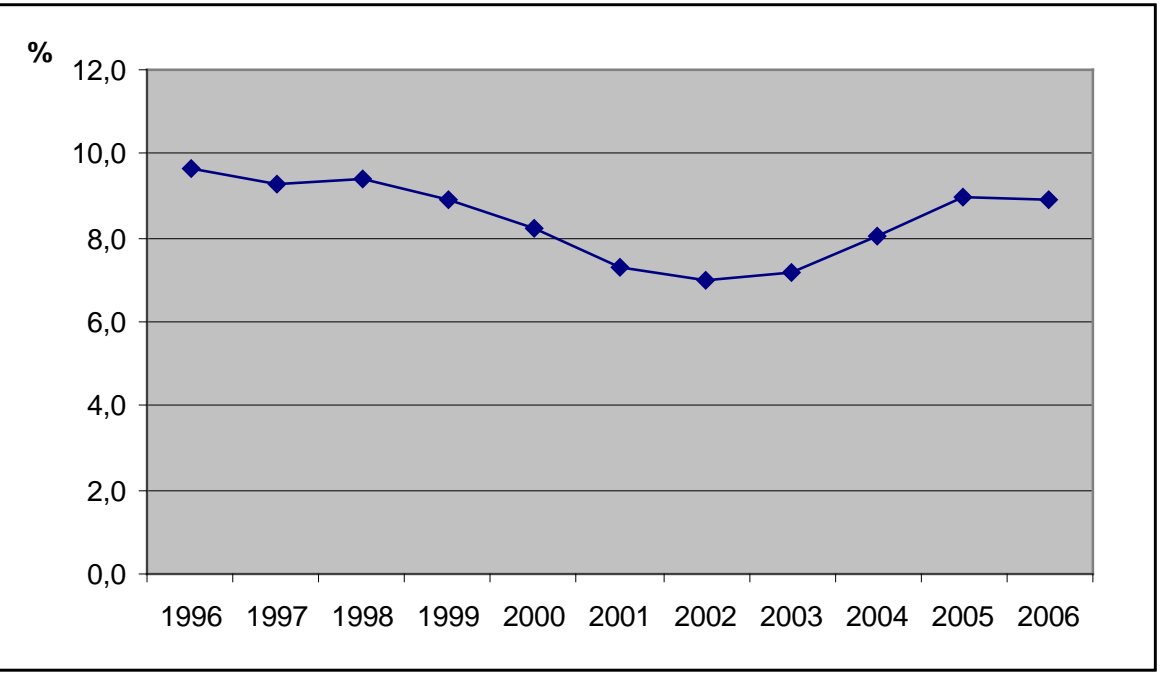

Bron: CBS (EBB)

Figuur 7.34 toont de ontwikkeling van het aandeel flexwerkers in de medische en paramedische beroepen. De medische en paramedische beroepen laten door de jaren een klein verval zien in het aandeel flexwerkers. Tot en met 1999 blijft dit aandeel min of meer constant. In 2000 daalt het aandeel vrij sterk. Hierna is er sprake van een licht dalende trend 
en in 2006 volgt er weer een kleine stijging. Het gemiddelde flexaandeel in deze beroepsklasse bedraagt $8,9 \%$.

Figuur 7.34

Aandeel flexwerk in medische en paramedische beroepen, 1996-2006

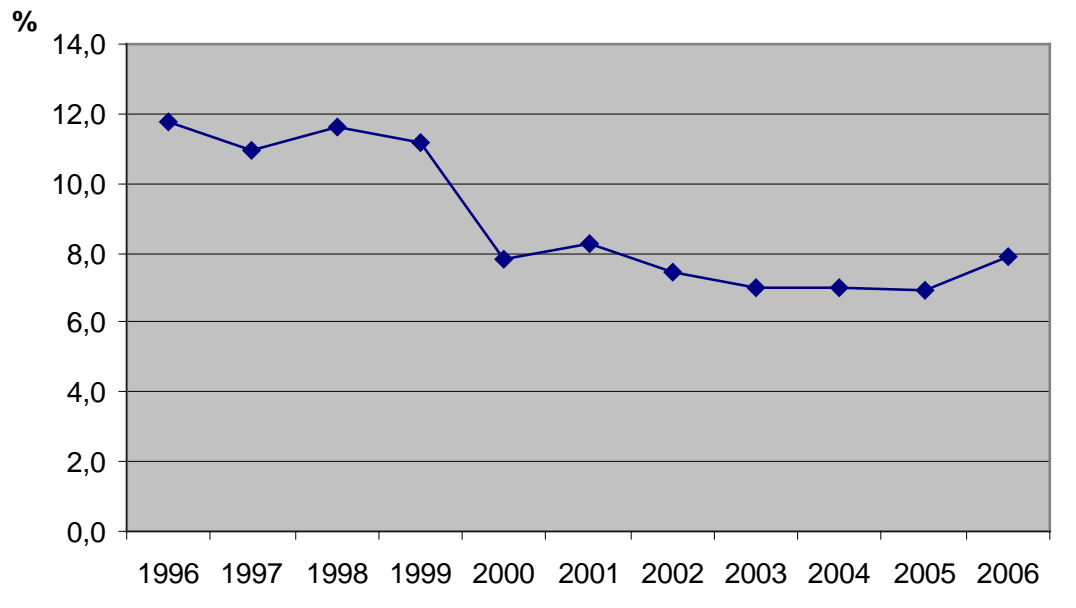

Bron: CBS (EBB)

Ook het aandeel flexwerkers in de sociaal-culturele beroepen, weergegeven in figuur 7.35, vertoont eenzelfde trendlijn. Met een flexaandeel van 6,7\% blijft deze beroepsklasse echter de helft achter bij het gemiddelde van het totaal aantal beroepen $(13,4 \%)$.

\section{Figuur 7.35}

Aandeel flexwerk in sociaal-culturele beroepen, 1996-2006

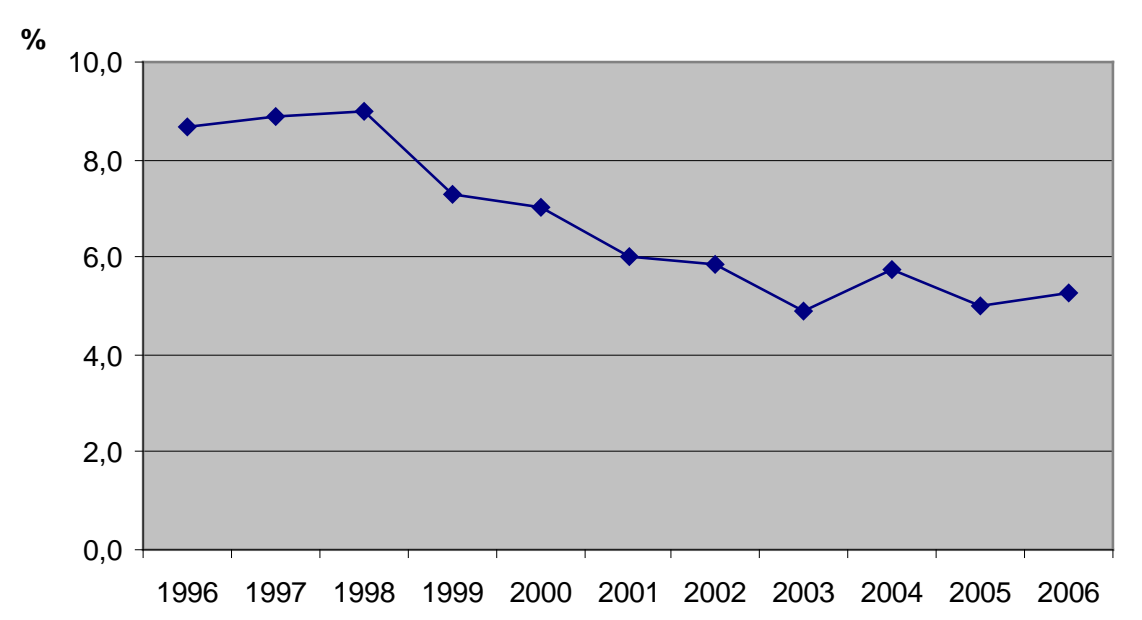

Bron: CBS (EBB)

In de openbare orde- en veiligheidsberoepen heeft gemiddeld genomen slechts 5,5\% van de werknemers een flexibel arbeidscontract. De trendlijn van het aandeel flexwerkers binnen deze beroepsklasse is licht stijgend. Verder is er een daling zichtbaar in 1998 en een stijging in 2003. 
Figuur 7.36

Aandeel flexwerk in openbare orde- en veiligheidsberoepen, 1996-2006

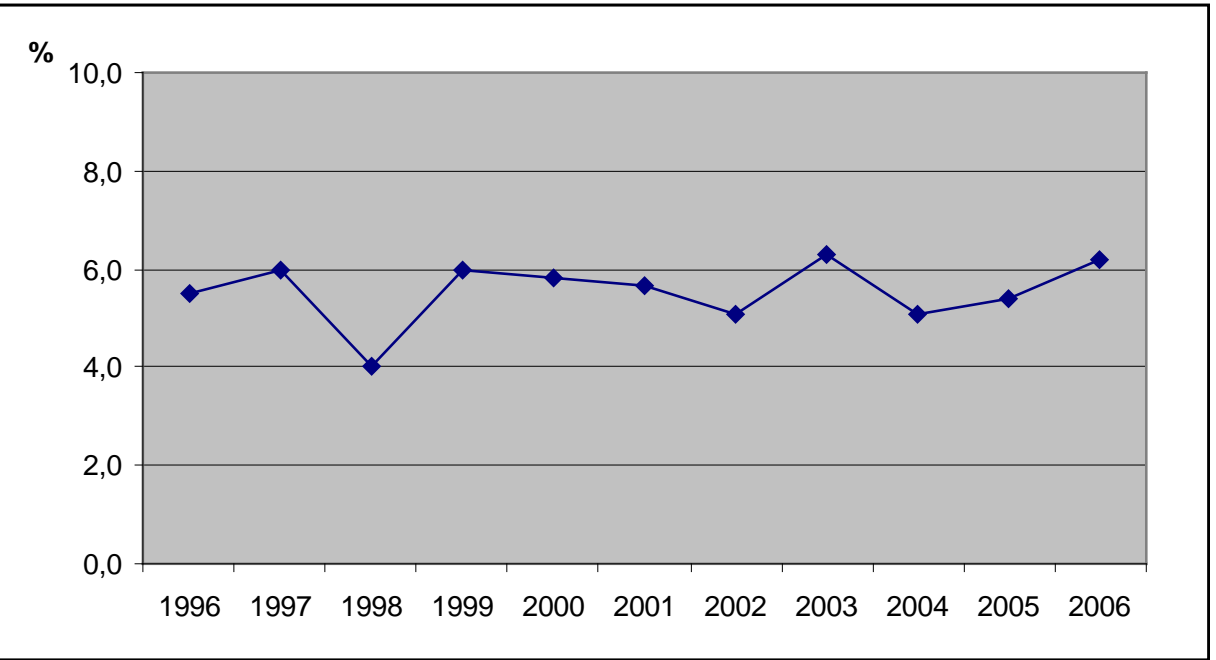

Bron: CBS (EBB)

Bijna één op de tien werknemers met een economisch-administratief beroep heeft een flexibele contractvorm (9,9\%). Uit figuur 7.37 blijkt dat het aandeel flexwerkers na 2000 afneemt en weer stijgt vanaf 2003.

Figuur 7.37

Aandeel flexwerk in economisch-administratieve beroepen, 1996-2006

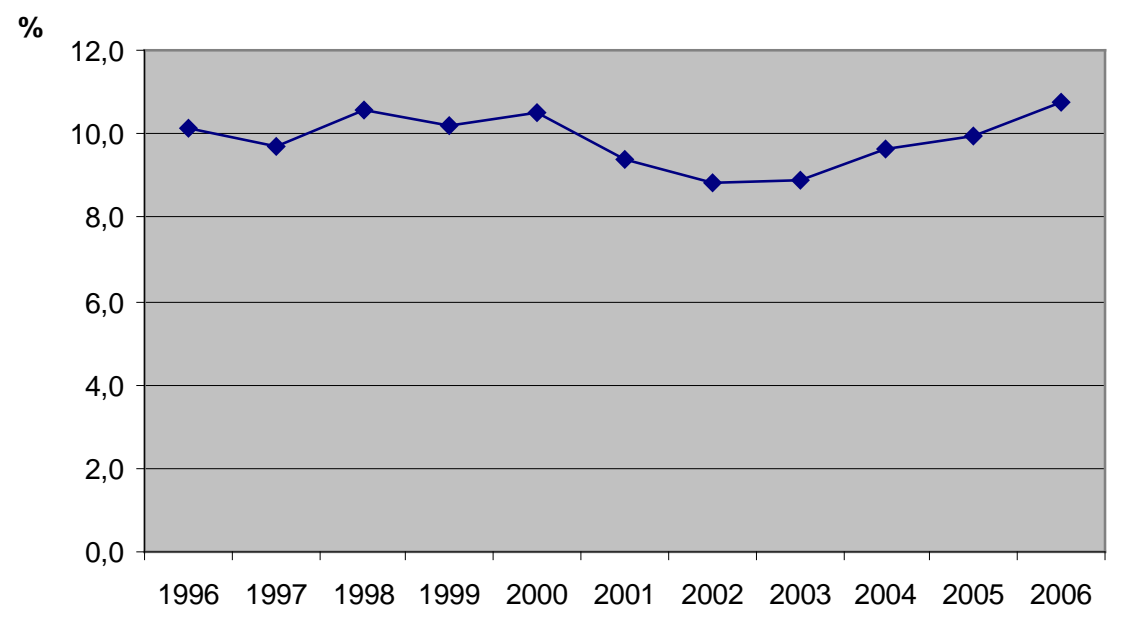

Bron: CBS (EBB)

Figuur 7.38 geeft de ontwikkeling weer van het aandeel flexwerkers voor de informaticaberoepen. Van alle beroepsklassen is het flexaandeel binnen de informaticaberoepen het kleinst. Slechts $4,5 \%$ van de werknemers binnen deze beroepsklasse heeft een flexibel contract. Van 1996 tot 1998 en van 2002 tot 2006 bevindt dit aandeel zich ongeveer op het zelfde niveau. Na 1998 vindt er een stijging plaats tot $6 \%$ in 2001, gevolgd door een vrij forse daling in 2002. 


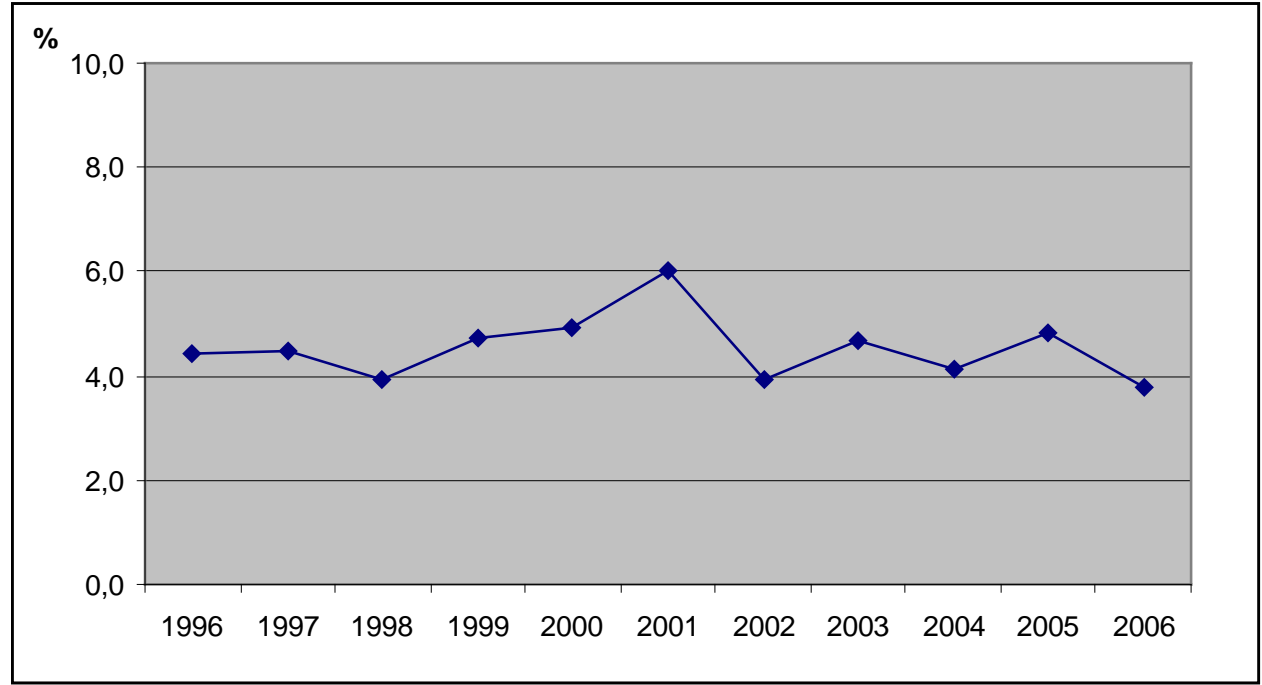

Bron: CBS (EBB)

Het flexaandeel binnen de culturele beroepen vertoont meer fluctuaties zoals blijkt uit figuur 7.39. In de hele periode 1996-2006 zijn schommelingen waarneembaar in het aandeel flexwerk binnen deze beroepsklasse. Gemiddeld heeft $16,8 \%$ van de werknemers binnen deze beroepsklassen een flexibel contract. In 2002 is het aandeel flexwerkers binnen deze beroepsklasse met ongeveer de $22 \%$ het grootst en een jaar later is dit aandeel het kleinst $(12 \%)$.

\section{Figuur 7.39}

Aandeel flexwerk in culturele beroepen, 1996-2006

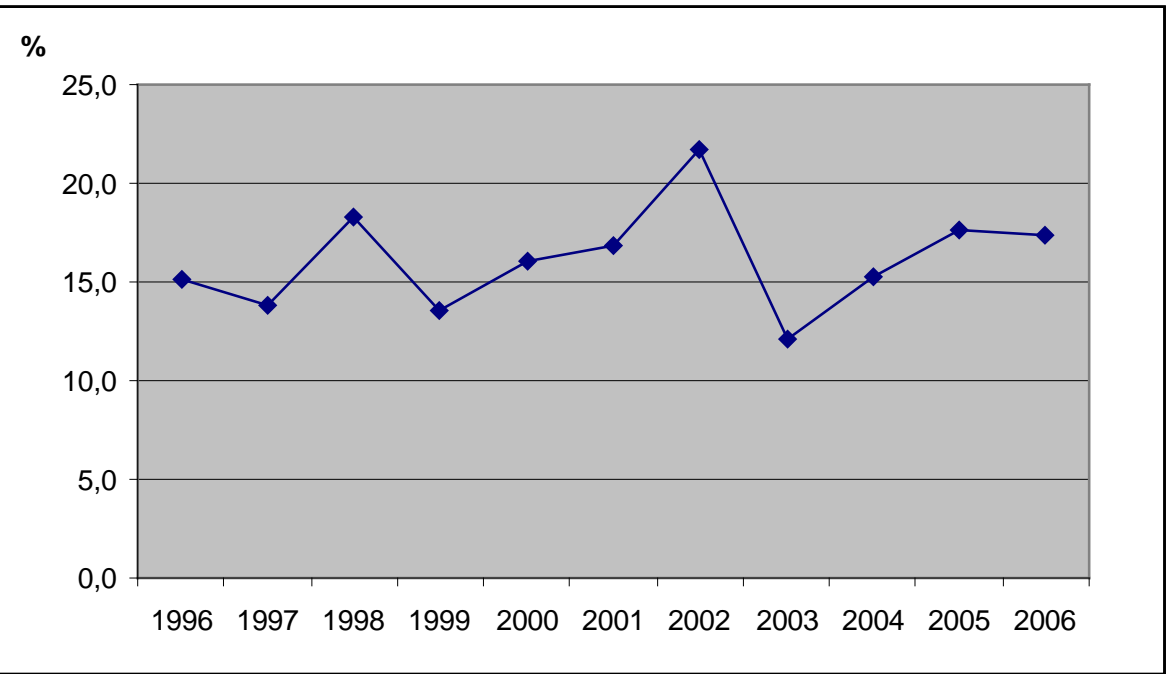

Bron: CBS (EBB)

Van alle beroepsklassen zijn er in de agrarische beroepen relatief gezien de meeste flexwerkers actief. In deze beroepsklasse heeft gemiddeld genomen namelijk meer dan $25 \%$ een flexibel contract, zoals blijkt uit figuur 7.40. Deze figuur laat fluctuaties zien met toppen 
in 1997, 2001 en 2005. In laatstgenoemd jaar heeft bijna drie op de tien werknemers met een agrarisch beroep een flexibel contract.

\section{Figuur 7.40}

Aandeel flexwerk in agrarische beroepen, 1996-2006

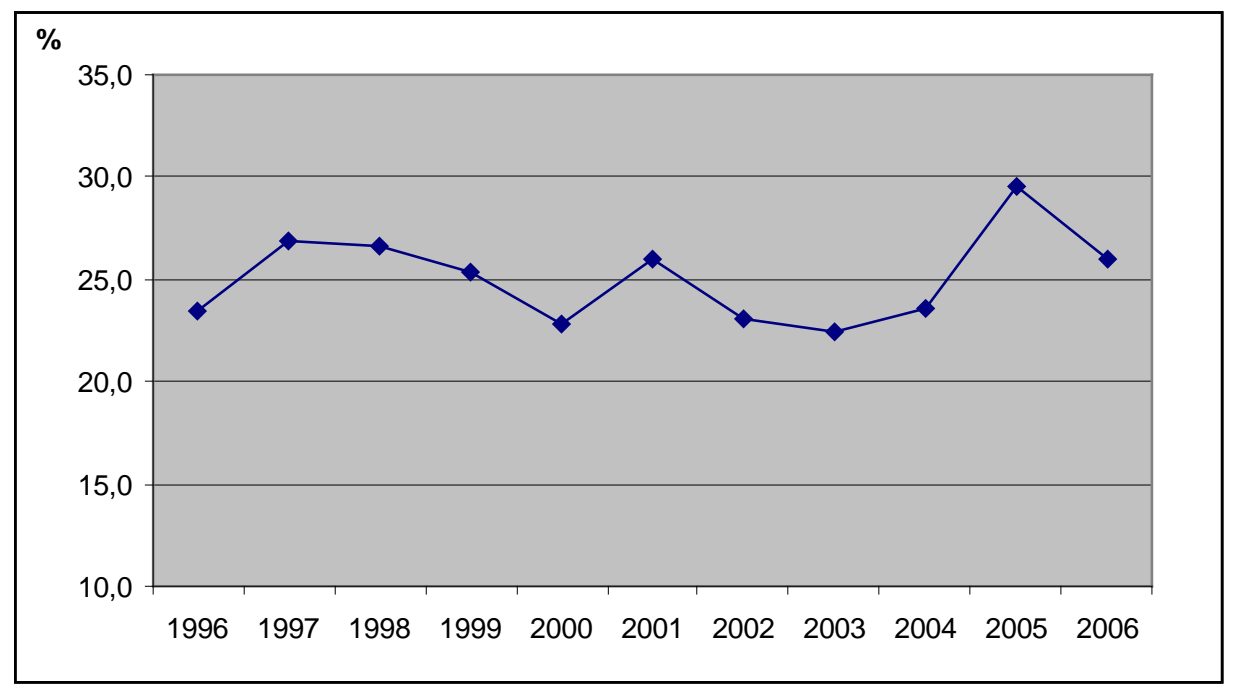

Bron: CBS (EBB)

Ook verzorgende en dienstverlenende beroepen worden relatief vaak door flexwerkers vervuld zoals blijkt uit figuur 7.41. Deze beroepsklasse noteert een flexaandeel van $24,1 \%$ over de gehele onderzoeksperiode. Na 1998 neemt het aandeel flexwerkers af, om vervolgens weer te stijgen tot boven de $25 \%$ in 2006.

\section{Figuur 7.41}

Aandeel flexwerk in verzorgende en dienstverlenende beroepen, 1996-2006

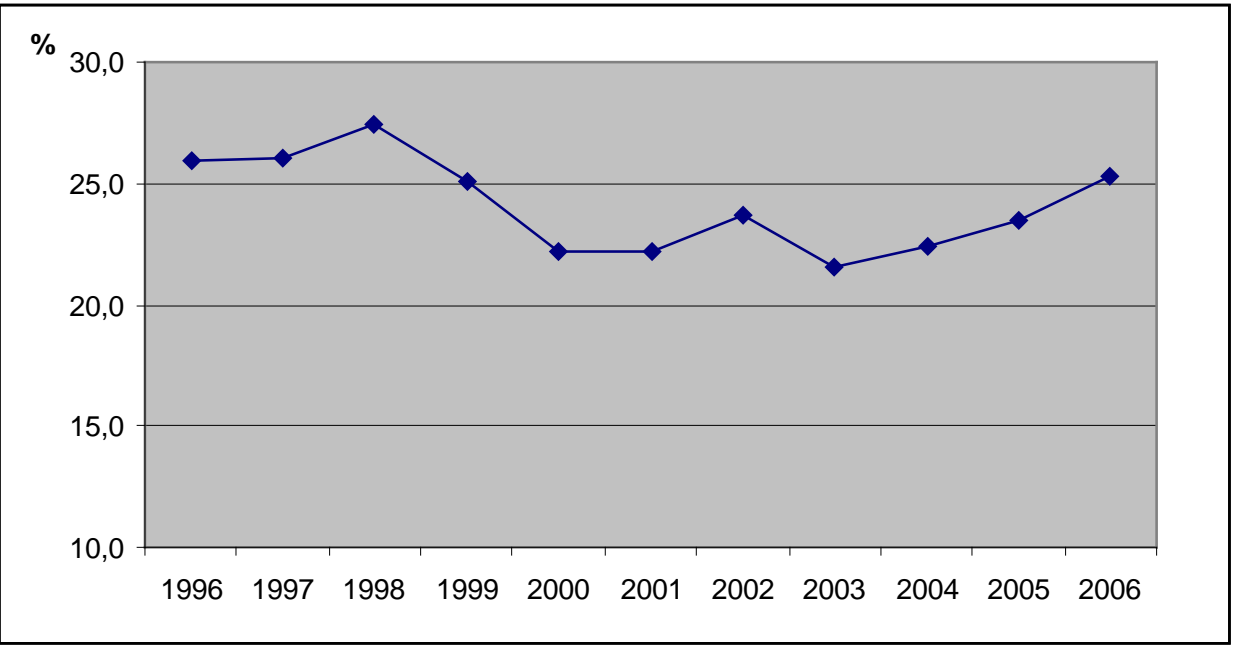

Bron: CBS (EBB)

De laatste beroepsklasse waarvan de ontwikkeling van het aandeel flexwerk besproken wordt is de transportberoepen. Uit figuur 7.42 kan afgeleid worden dat dit aandeel gedurende eerste jaren behoorlijk schommelt. Na 2003 stijgt het aandeel flexwerkers in deze 
beroepsklasse. Gemiddeld heeft 17,3\% van de werknemers in de transportberoepen een flexibel contract.

Figuur 7.42

Aandeel flexwerk in transportberoepen, 1996-2006

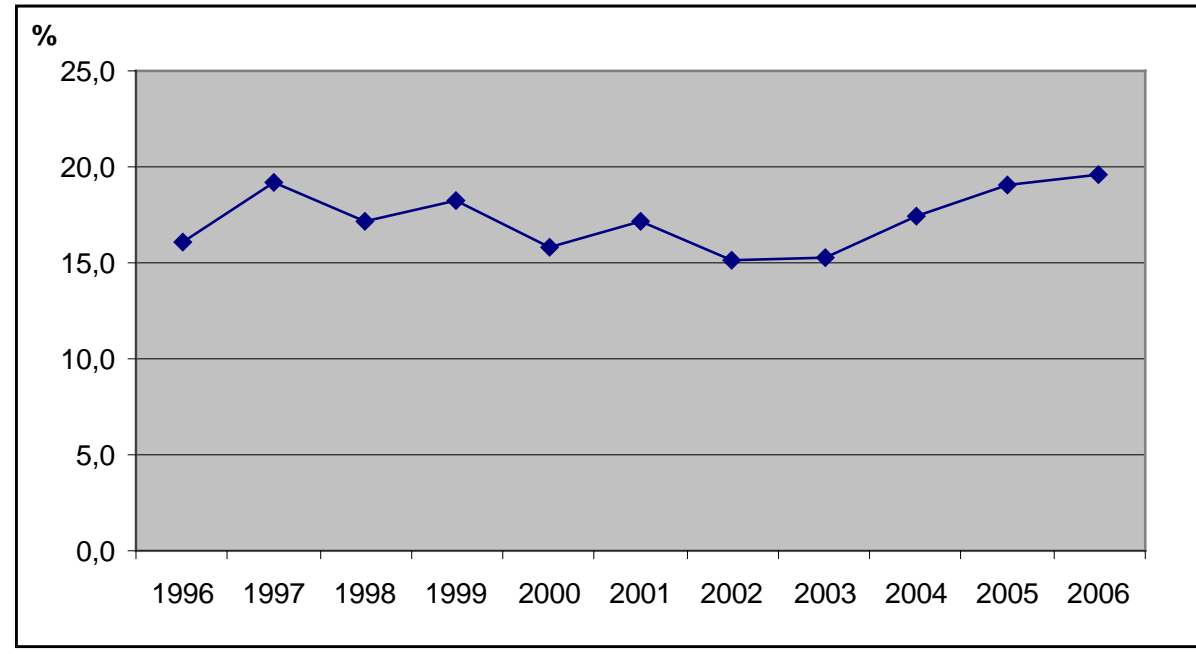

Bron: CBS (EBB)

\section{Conclusies}

In dit werkdocument werd het belang van flexwerk op de arbeidsmarkt onderzocht. Hierbij zijn verschillende aspecten van flexwerk aan bod gekomen. Allereerst zijn er verschillende verschijningsvormen (o.a. contracten voor bepaalde tijd, uitzend- en oproepkrachten) van flexibele arbeid besproken. Vervolgens bespraken we het belang van een aantal van deze verschijningsvormen op de Nederlandse arbeidsmarkt en in internationale context.

Daarnaast geeft dit werkdocument de beweegredenen weer die werknemers en werkgevers volgens de economische literatuur kunnen hebben bij het aangaan van een flexibel dienstverband. Voor werkgevers kunnen flexibele contracten dienen om vraagschommelingen en tijdelijke absenties van het eigen personeel op te vangen. Ook kunnen werkgevers flexibele contracten bijvoorbeeld gebruiken als screeningsinstrument. Voor werklozen kan flexibele arbeid uitkomst bieden om de arbeidsmarkt (opnieuw) te betreden. Een ander belangrijk argument voor deze groep is dat een flexibel dienstverband kan dienen als springplank naar een vast dienstverband ('stepping stone' hypothese).

Tevens bespreekt dit werkdocument de Nederlandse wetgeving die een rol speelt bij het verklaren van de omvang van flexibele ten opzichte van vaste arbeidsrelaties. De aantrekkelijkheid van flexwerk ten opzichte van vaste dienstverbanden wordt namelijk onder andere bepaald door het ontslagrecht bij beide soorten arbeidsrelaties. Indien de ontslagkosten van flexwerkers ten opzichte van vaste arbeidskrachten dalen dan wordt het voor werkgevers aantrekkelijker om flexwerkers in te zetten. In dit kader zijn daarom belangrijke veranderingen in de wetgeving behandeld (invoering WAADI in 1998 en Flexwet in 1999). Ook de hieruit voortvloeiende ABU-cao's werden daarbij toegelicht. 
Het werkdocument bevat ook een overzicht van de belangrijkste achtergrondkenmerken van werknemers met een flexibele arbeidsrelatie. In het algemeen kan gesteld worden dat vrouwen, allochtonen, jongeren en laagopgeleiden relatief vaak een flexibele contractvorm hebben.

Tussen 1996 en 2006 is de horeca (39,3\%) de sector met het grootste aandeel flexwerkers, terwijl er in dezelfde periode in de handel en reparatie absoluut gezien de meeste flexwerkers actief zijn (gemiddeld 154.000). Wanneer we kijken naar het aandeel flexwerkers per opleidingsniveau, zien we dat er belangrijke verschillen bestaan tussen schoolverlaters en werknemers. Eerstgenoemde groep heeft vaker een flexibel contract en het aandeel flexwerkers van deze groep fluctueert meer dan het aandeel flexwerkers onder werknemers. Onder werknemers hebben lager opgeleiden meer kans op een flexibel contract. Van alle beroepsklassen hebben de agrarische beroepen het grootste aandeel flexwerkers. In deze beroepen heeft gemiddeld meer dan $25 \%$ een flexibel contract.

Tot slot zijn we ingegaan op de ontwikkeling van flexibele arbeid, zowel op macroniveau als in de verschillende sectoren, opleidingen en beroepen. Gegeven de grote aandacht voor het stimuleren van de flexibilisering van arbeid zou men kunnen verwachten dat het aandeel flexibele arbeidskrachten flink is toegenomen. Het blijkt echter dat de flexibilisering van de arbeid tussen 1996 en 2006 niet is voortgeschreden. Voor deze periode geldt dat het relatieve aantal personen dat in vaste dienst werkt rond de $90 \%$ ligt. Er lijkt wel een relatie met de conjuncturele ontwikkeling te zijn. Een stijging van het aandeel flexibele arbeid is verklaarbaar uit het aantrekken van de economie, waardoor werkgevers in eerste instantie relatief vaak flexibele arbeidskrachten aanstellen. Nadat de arbeidsmarkt zich heeft hersteld en de werkloosheid terugloopt naar het natuurlijke niveau, kan er krapte op de arbeidsmarkt ontstaan. Werknemers kunnen dan hogere eisen stellen aan de secundaire arbeidsvoorwaarden, waaronder de contractduur. Derhalve zal het aandeel flexibele arbeid daarna weer dalen. Vervolgens daalt het aandeel verder als de economische groei stagneert, waardoor flexibele arbeidskrachten als eerste op straat komen te staan.

Aangezien er op macroniveau tussen 1996 en 2006 nauwelijks veranderingen hebben plaatsgevonden met betrekking tot het aandeel flexwerk, is er ook gekeken of er wel veranderingen hebben plaatsgevonden binnen de verschillende sectoren, opleidingen en beroepsklassen. Er blijken behoorlijke verschillen te zijn tussen de verschillende sectoren, opleidingen en beroepsklassen, zowel qua aandeel flexwerk als qua verschijningvorm. 


\section{Referenties}

ABU (2007), Samenvatting CAO voor Uitzendkrachten 2004 - 2009, januari.

Autor, D.H. (2001), Why do temporary help firms provide free general skills training?, Quarterly Journal of Economics, Vol. 116, pp. 1409-48.

Autor, D.H. (2003), Outsourcing at will: The contribution of unjust dismissal doctrine to the growth of employment outsourcing, Journal of Labor Economics, Vol. 21, pp. 1-42.

Autor, D.H. (2004), Labor Market Intermediation: What It Is, Why It Is Growing, and Where It Is Going, NBER Working Papers.

Autor, D.H. and S.N. Houseman (2005), Do Temporary Help Jobs Improve Labor Market Outcomes for Low-Skilled Workers? Evidence from Random Assignments, mimeo, October 2005.

Beer, P. de (1996), Het onderste kwart: werk en werkloosheid aan de onderkant van de arbeidsmarkt, Sociaal en Cultureel Planbureau, Rijswijk.

Bentolila, S. and Dolado, J.J. (1994), Labour Flexibility and Wages: Lessons from Spain, Economic Policy, Vol. 9 (18), pp. 55-99.

Berkhout, E.E. en M.J. Van Leeuwen (2004), International database on employment and adaptable labour (IDEAL), Randstad Jobs Report 2004, SEO-report 642, SEO Economic Research, Amsterdam.

Bierings, H. en C. Siermann (2006), Meer vraag naar flexibele arbeid, Webmagazine, 11 september, CBS, Heerlen.

Cörvers, F. en R. Montizaan (2006), Hoe voorzien werkgevers in hun flexibiliteitsbehoefte? Economisch Statistische Berichten, ESB-dossier ICT en economische groei, Vol. 91, pp. 2731.

De Beer, P.T. (2004), Flexibilisering maakt banengroei fragiel, Economisch Statistische Berichten, Vol. 89, pp. 434-436.

De Graaf-Zijl, M. (2005), The attractiveness of temporary employment to reduce adjustment costs: A conjoint analysis, Tinbergen Institute Discussion Paper, TI 2005/121/3, Universiteit van Amsterdam, Tinbergen Institute.

Delsen, L. (1995), Atypical Employment: An international perspective, Causes, consequences and policy, Wolters-Noordhoff, Groningen. 
Donker van Heel, P., E. van Nuland en M. van der Ende (2007), Instroom uitzendkrachten 2006, ECORYS, Rotterdam.

Ecorys-NEI (2002), Rationale of agency work - European labour suppliers and demanders' motives to engage in agency work, Rotterdam.

European Commission (2003), Employment in Europe 2003: Recent trends and prospects, Luxembourg.

Goudswaard, A. (2003), Flexibele arbeid - duurzame arbeid? De stand van zaken na twintig jaar flexibilisering van arbeid, proefschrift, TNO Arbeid, Hoofddorp.

Güell, M. (2000), Fixed-Term Contracts and Unemployment: An Efficiency Wage Analysis, CEP Discussion Papers 0461, Centre for Economic Performance, LSE.

Haan E. de, P. Vos, Ph. de Jong (1994), Flexibilisering van de arbeid, Welboom, wetenschappelijke pubilikaties nationaal vakbondsmuseum, Den Haag.

Houseman, S.N. (2001), Why Employers Use Flexible Staffing Arrangements: Evidence from an Establishment Survey, Industrial and Labor Relations Review, Vol. 55, pp. 149-170.

Houseman, S.N., A.L. Kalleberg, G.A. Erickcek (2003), The role of temporary help employment in tight labor markets, Industrial and Labor Relations Review, Vol. 57, pp. 105127.

Knegt, R., D.J. Klein Hesselink, H. Houwing, P. Brouwer (2007), Tweede evaluatie Wet flexibiliteit en zekerheid, HSI/TNO, Amsterdam en Hoofddorp.

Mitlacher, L.W. (2006), The organization of Human Resource Management in temporary work agencies - towards a comprehensive research agenda on temporary agency work in Germany, the Netherlands and the US, Human Resource Management Review, Vol. 16, pp. 67-81.

NEI (2003), Naar een nieuw evenwicht? Evaluatie van de Wet Flexibiliteit en Zekerheid, Eindrapport, in opdracht van de Algemene Bond Uitzendondernemingen, Rotterdam, april.

OECD (2002), Employment Outlook, Parijs.

Picchio (2006), Do temporary workers suffer a wage penalty? Investigating the Italian case using panel data approach, Quaderni di Ricerca No. 268, Universita Politecnica Delle Marche.

Polivka, A.E. en Nardone, T. (1989), On the definition of contingent work, Monthly Labor Review, Vol. 112, pp. 9-16. 
Pot, F., Koene, B. en Paauwe, J. (2001), Contingent employment in The Netherlands, ERIM Working Paper.

Rebitzer, J. B. \& Taylor, L.J, (1991), A Model of Dual Labor Markets When Product Demand Is Uncertain, Quarterly Journal of Economics, MIT Press, vol. 106 (4), p. 1373-83.

ROA (2009), De arbeidsmarkt naar opleiding en beroep tot 2014, ROA-R-2009/5, Maastricht.

Rosen, S. (1974), Hedonic prices and implicit markets: Product differentiation in pure competition, Journal of Political Economics, Vol. 82, pp. 34-55.

Smits, W. en J. Samadhan (2002), Flexibiliteit en zekerheid: Tweede monitoronderzoek naar de invulling van Flexbepalingen in de CAO's per 1 september 2001, Ministerie van Sociale Zaken en Werkgelegenheid, Arbeidsinspectie, Den Haag.

STAR (2004), Aanbeveling inzake de regeling van arbeidsvoorwaarden van uitzendwerkers, Den Haag.

Storrie, D. (2002), Temporary agency work in the European Union, European Foundation for the Improvement of Living and Working Conditions, Dublin.

Torka, N. (2003), Flexibel maar toch betrokken, proefschrift, Universiteit van Twente, Enschede.

Van den Toren, J., G. Evers, E. Commissaris (2002), Flexibiliteit en zekerheid: Effecten en doeltreffendheid van de Wet Flexibiliteit en Zekerheid, Ministerie van Sociale Zaken en Werkgelegenheid, Doetichem.

Voogdt-Pruis, H. (1998), Van een tijdelijk naar een vast contract, Sociaal-Economische Dynamiek 1998, CBS, Heerlen, p. 34-39.

Zijl, M. (2006), Economic and social consequences of temporary employment, Academisch proefschrift, Tinbergen Institute Research Series, Amsterdam.

Zijl, M., Berkhout, E., Korteweg, J.A., Sol, E. en Aerts, M. (2003), Uitzendwerk en conjunctuur: Motieven van werkgevers en de gevolgen voor de samenloop met conjunctuur, SEO rapport, Amsterdam.

Zijl, M, G.J. van den Berg, and A. Heyma (2004), Stepping Stones for the Unemployed: The Effect of Temporary Jobs on the Duration until Regular Work, IZA Discussion Paper No. 1241, Institute for the Study of Labor, Bonn. 


\section{Bijlage I Flexwerk per beroepsklasse}

\section{Figuur I.1}

Aandeel verschijningsvormen flexwerk in beroepsklassen totaal, 1996-2006

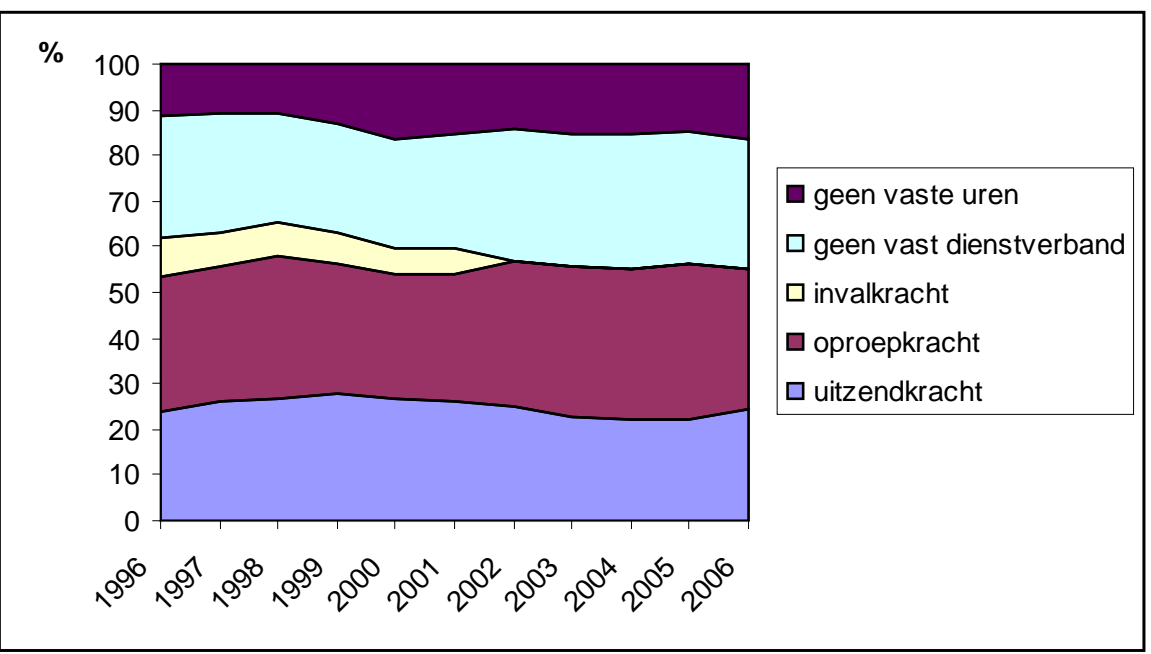

Bron: CBS (EBB)

\section{Figuur $\mathbf{1 . 2}$}

Aandeel verschijningsvormen flexwerk in pedagogische beroepen, 1996-2006

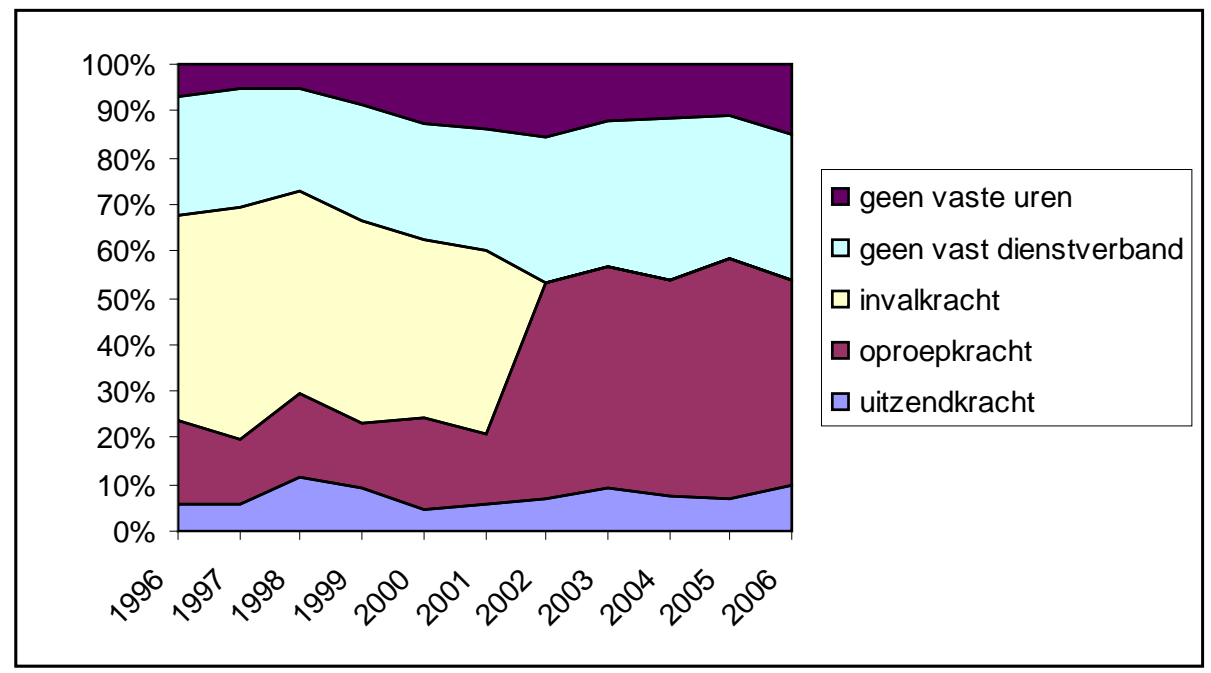

Bron: CBS (EBB) 
Figuur I. 3

Aandeel verschijningsvormen flexwerk in technische en industrieberoepen, 1996-2006

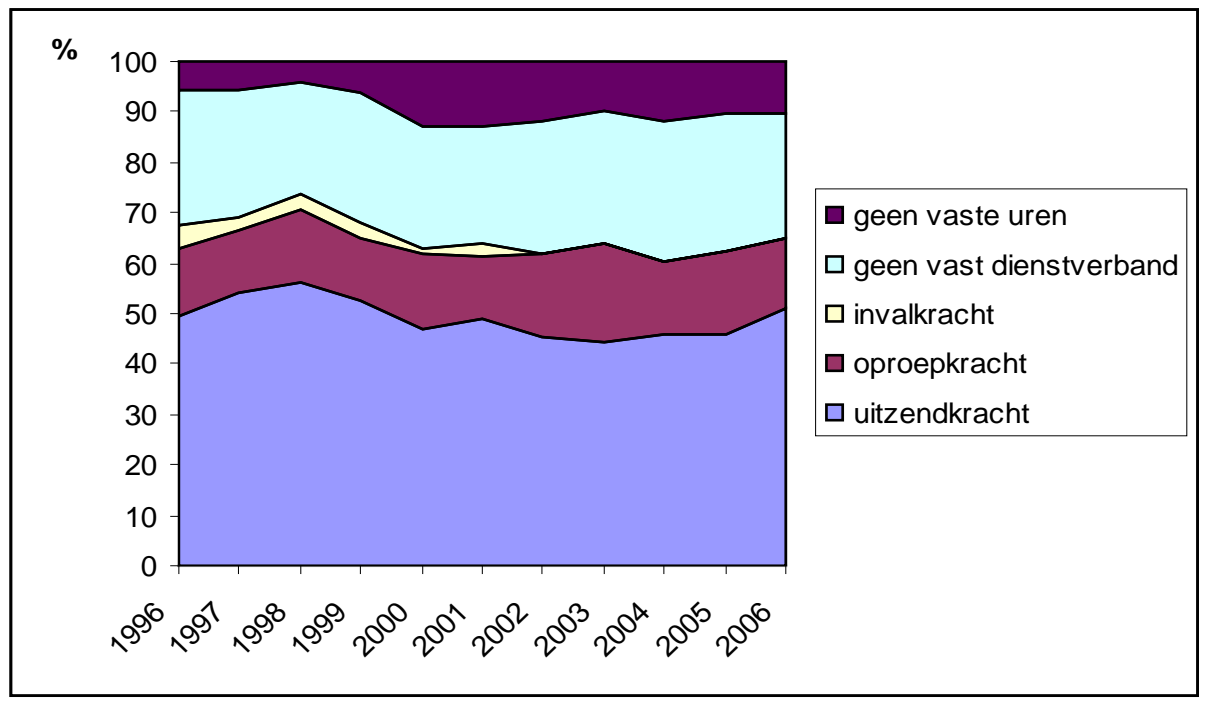

Bron: CBS (EBB)

\section{Figuur 1.4}

Aandeel verschijningsvormen flexwerk in medische en paramedische beroepen, 1996-2006

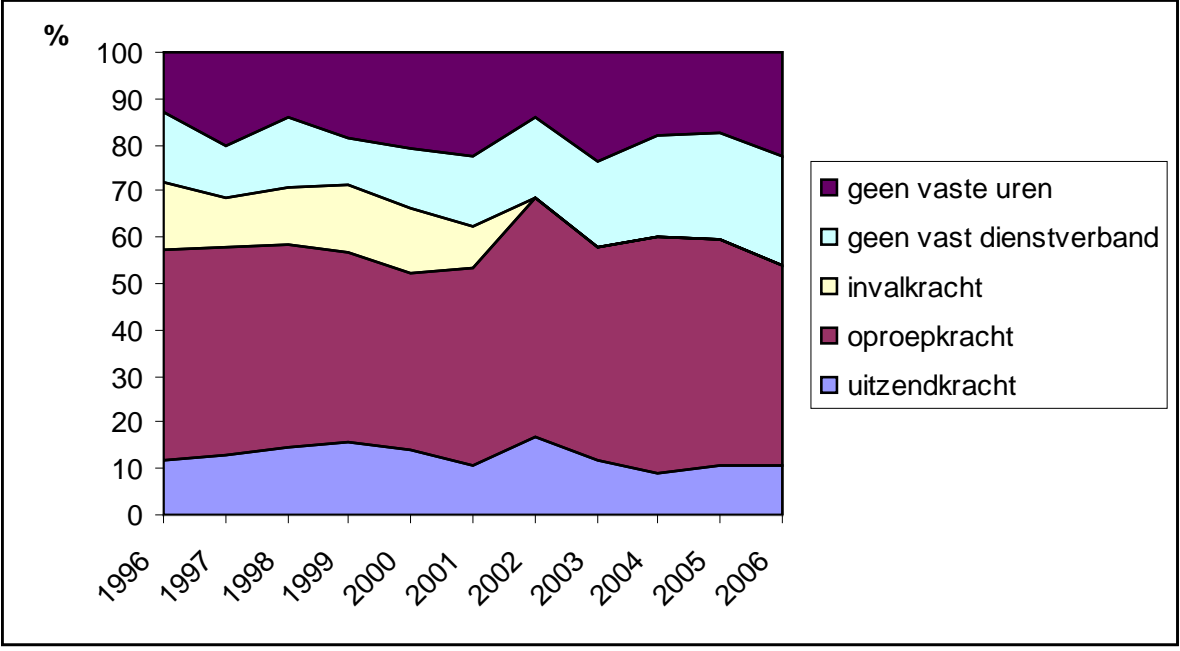

Bron: CBS (EBB) 
Figuur 1.5

Aandeel verschijningsvormen flexwerk in sociaal-culturele beroepen, 1996-2006

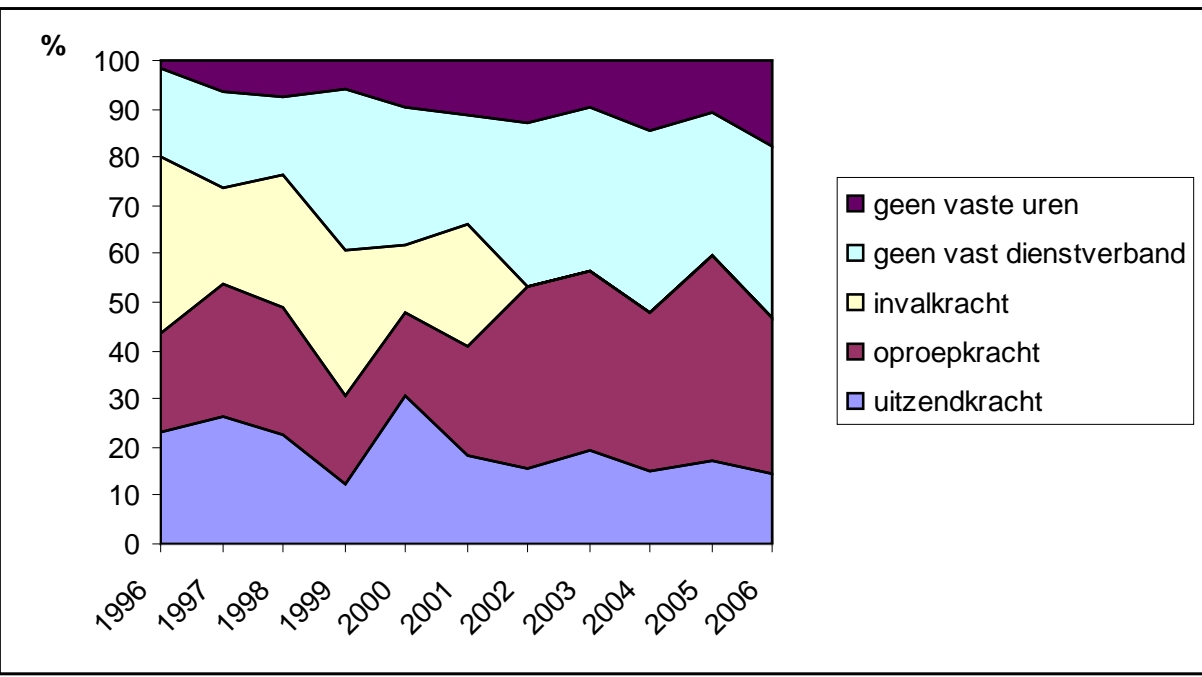

Bron: CBS (EBB)

Figuur I.6

Aandeel verschijningsvormen flexwerk in openbare orde en veiligheidsberoepen, 1996-2006

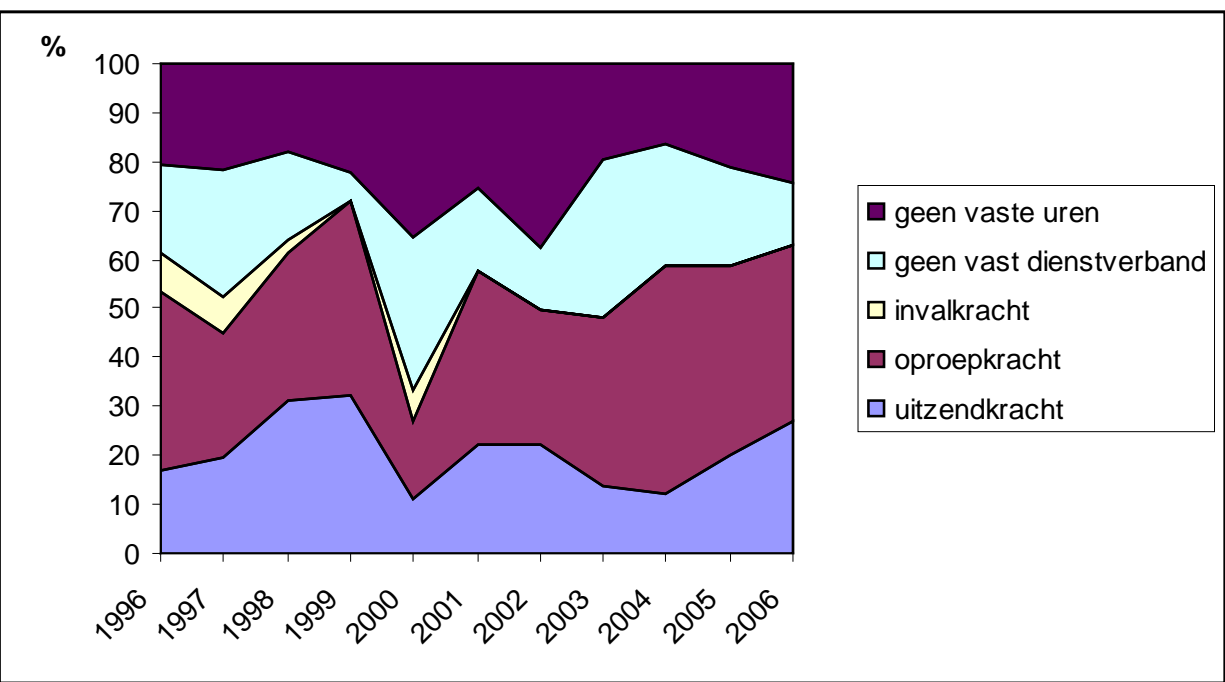

Bron: CBS (EBB) 
Figuur $\mathbf{1 . 7}$

Aandeel verschijningsvormen flexwerk in economisch-administratieve beroepen, 1996-2006

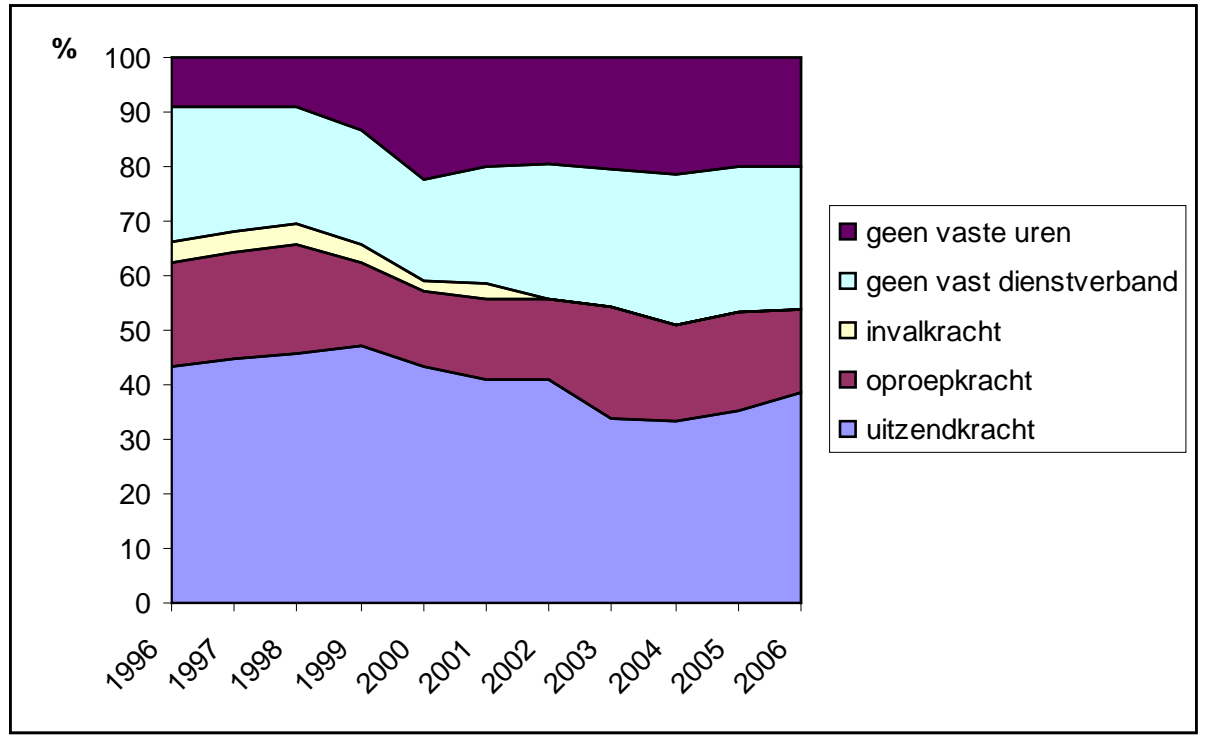

Bron: CBS (EBB)

\section{Figuur I.8}

Aandeel verschijningsvormen flexwerk in informaticaberoepen, 1996-2006

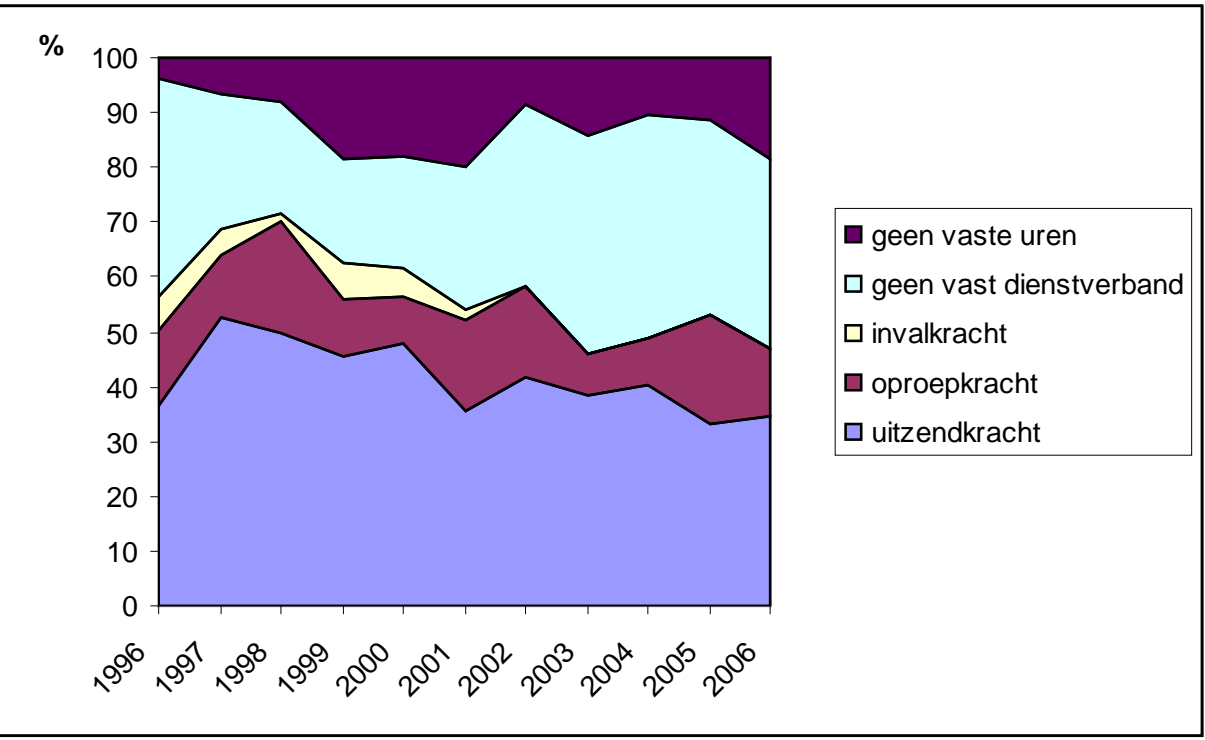

Bron: CBS (EBB) 
Figuur 1.9

Aandeel verschijningsvormen flexwerk in culturele beroepen, 1996-2006

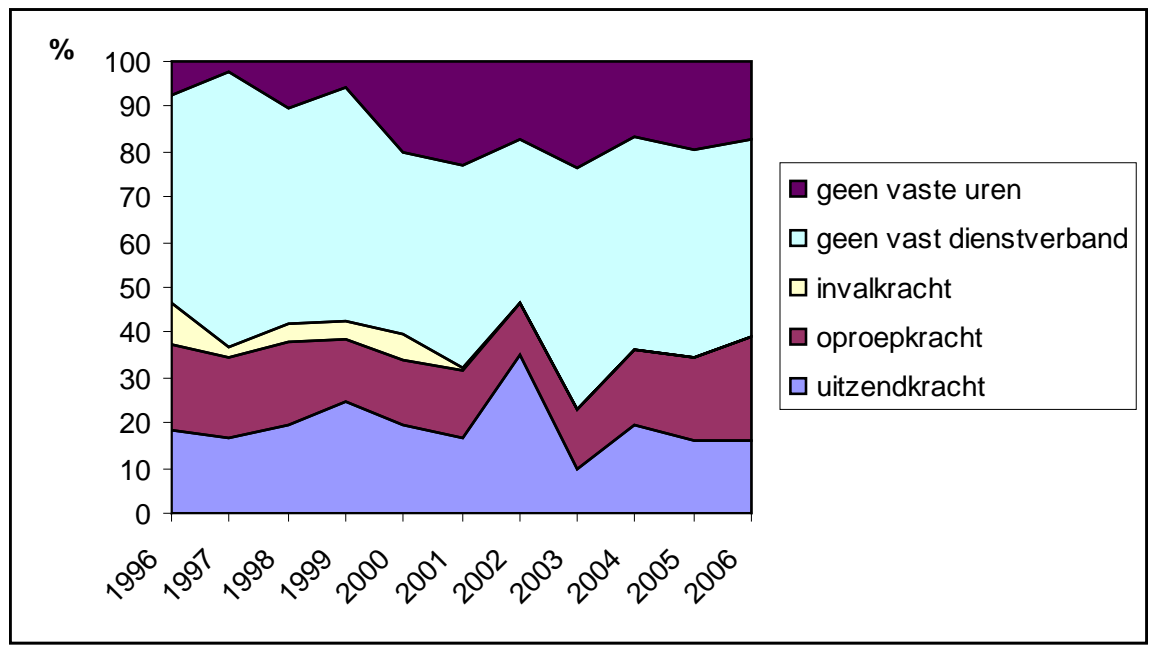

Bron: CBS (EBB)

\section{Figuur I.10}

Aandeel verschijningsvormen flexwerk in agrarische beroepen, 1996-2006

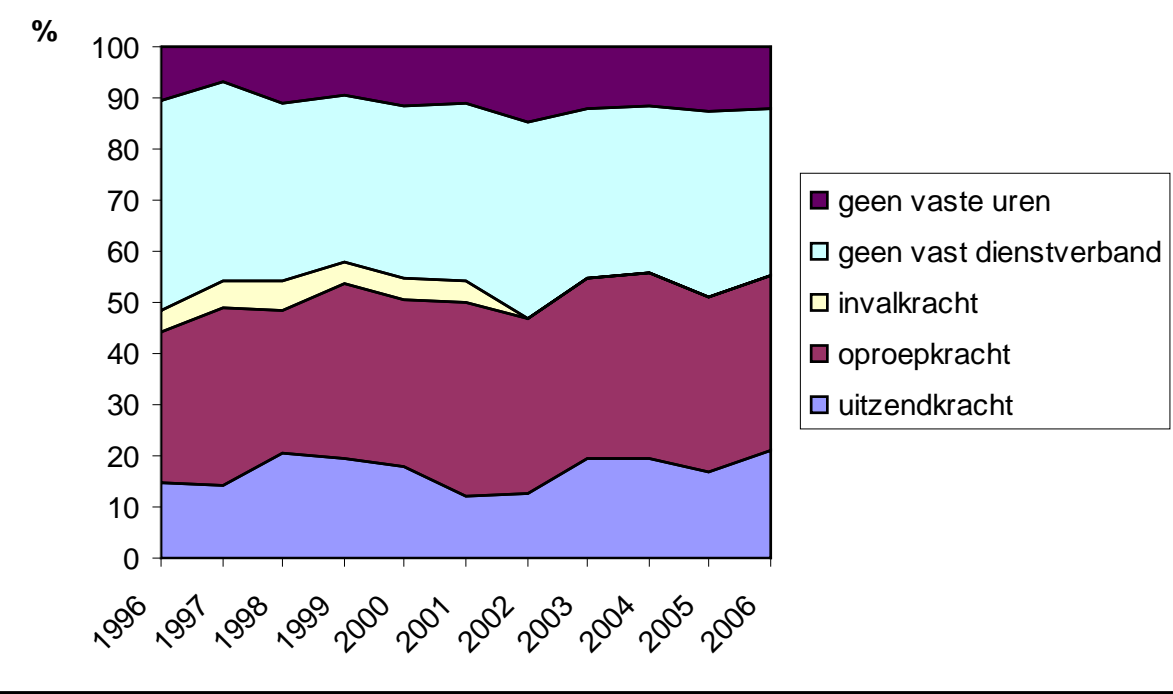

Bron: CBS (EBB) 
Figuur I.11

Aandeel verschijningsvormen flexwerk in verzorgende en dienstverlenende beroepen, 1996-2006

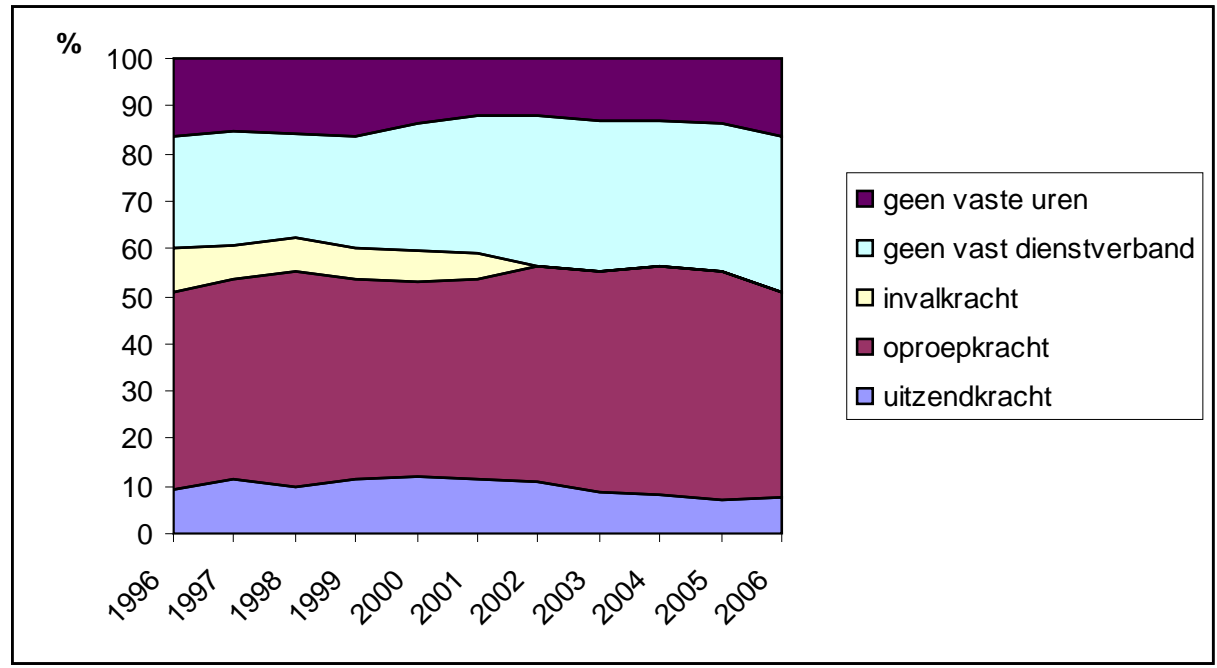

Bron: CBS (EBB)

\section{Figuur I.12}

Aandeel verschijningsvormen flexwerk in transportberoepen, 1996-2006

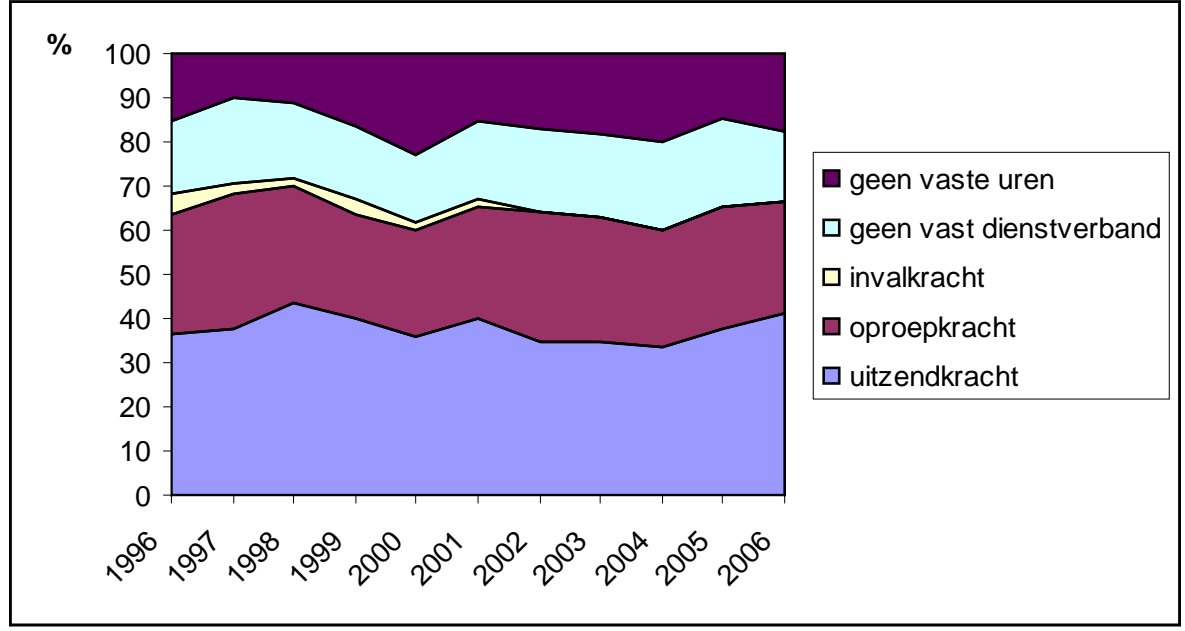

Bron: CBS (EBB) 


\section{Bijlage II Flexwerk per opleidingsniveau}

Figuur II.1

Aandeel verschijningsvormen flexwerk in basisonderwijs, 1996-2006

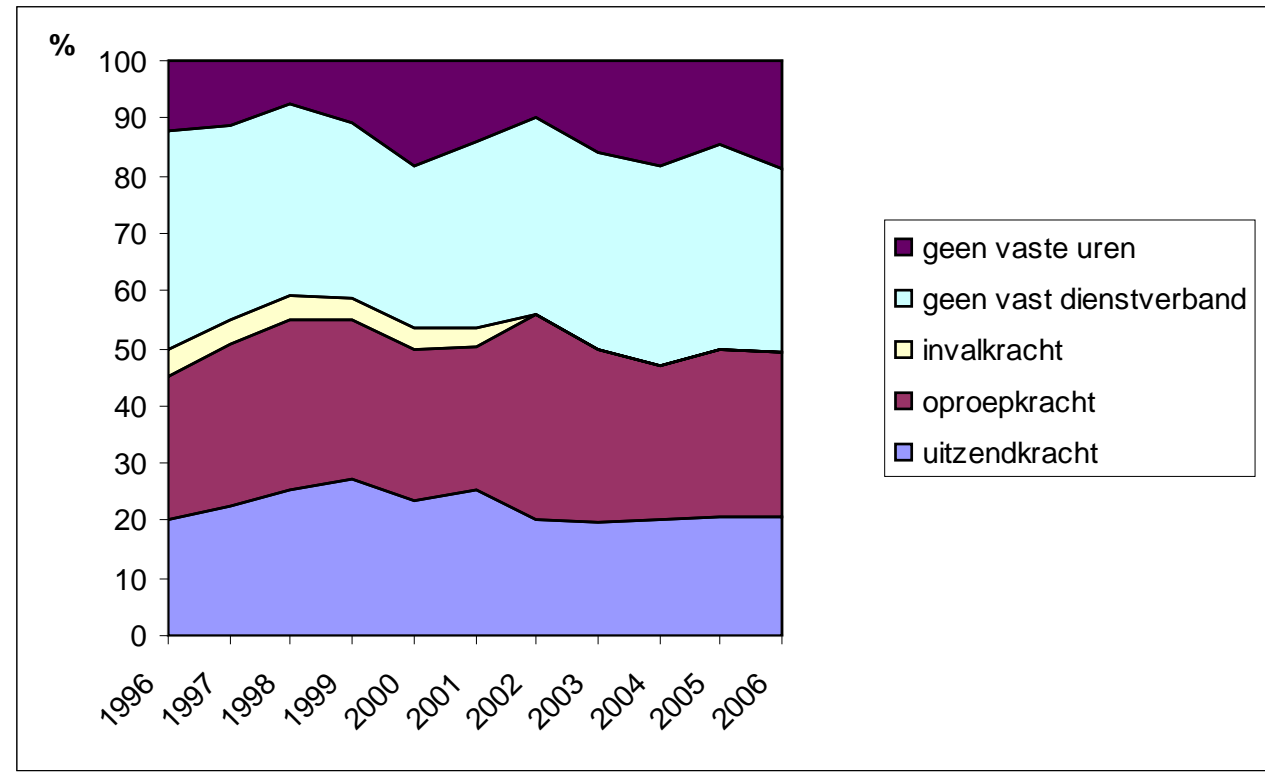

Bron: CBS (EBB)

Figuur II.2

Aandeel verschijningsvormen flexwerk in VMBO, 1996-2006

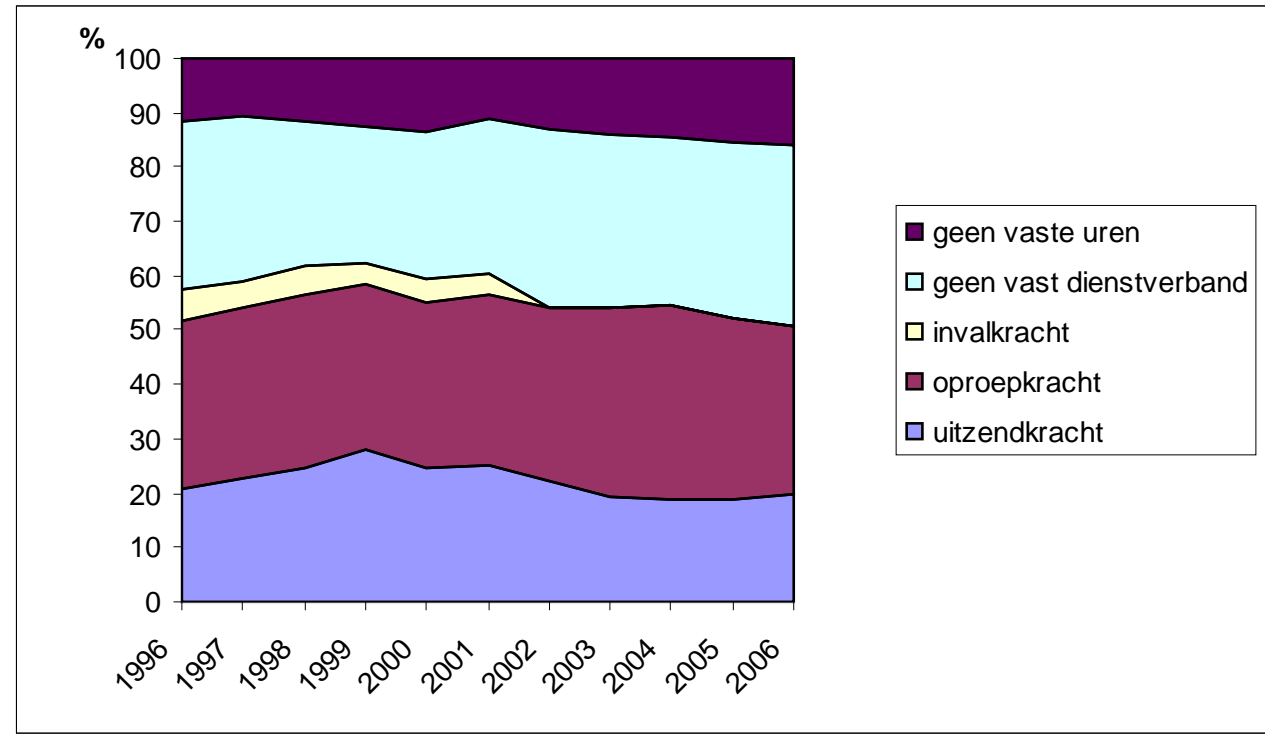

Bron: CBS (EBB) 
Figuur II.3

Aandeel verschijningsvormen flexwerk in HAVO/VWO, 1996-2006

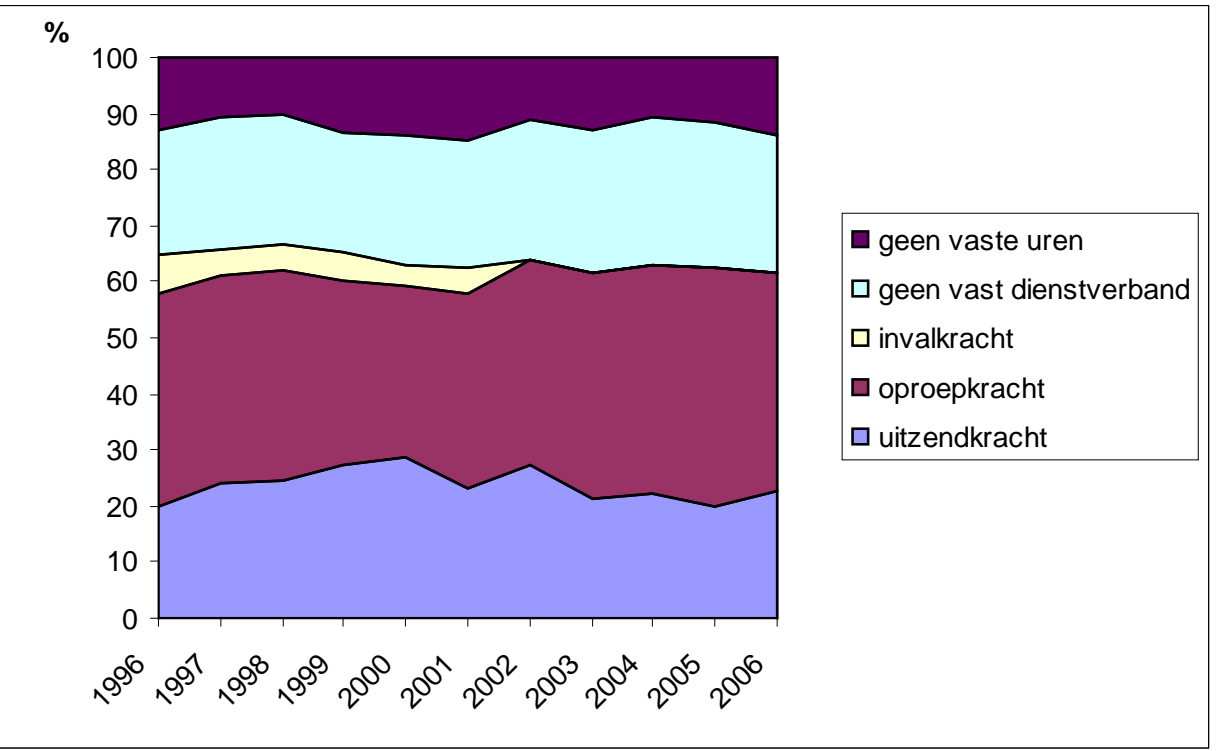

Bron: CBS (EBB)

Figuur II.4

Aandeel verschijningsvormen flexwerk in MBO, 1996-2006

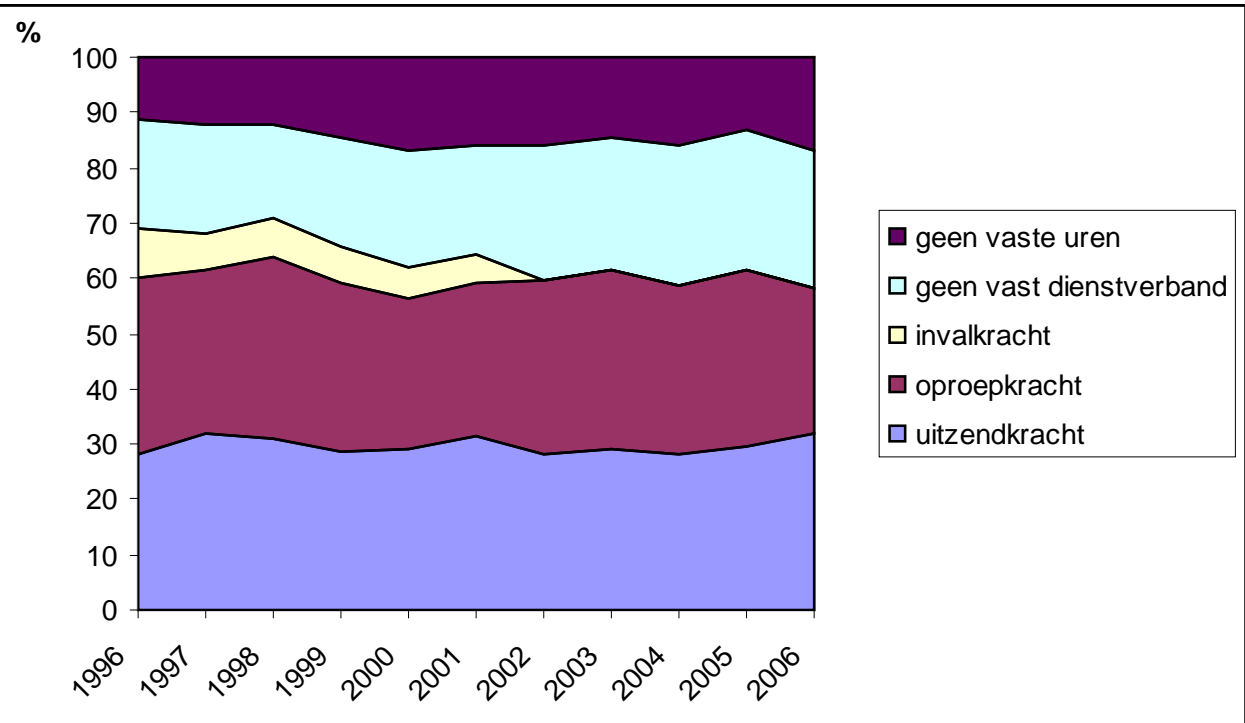

Bron: CBS (EBB) 
Figuur II.5

Aandeel verschijningsvormen flexwerk in HBO, 1996-2006

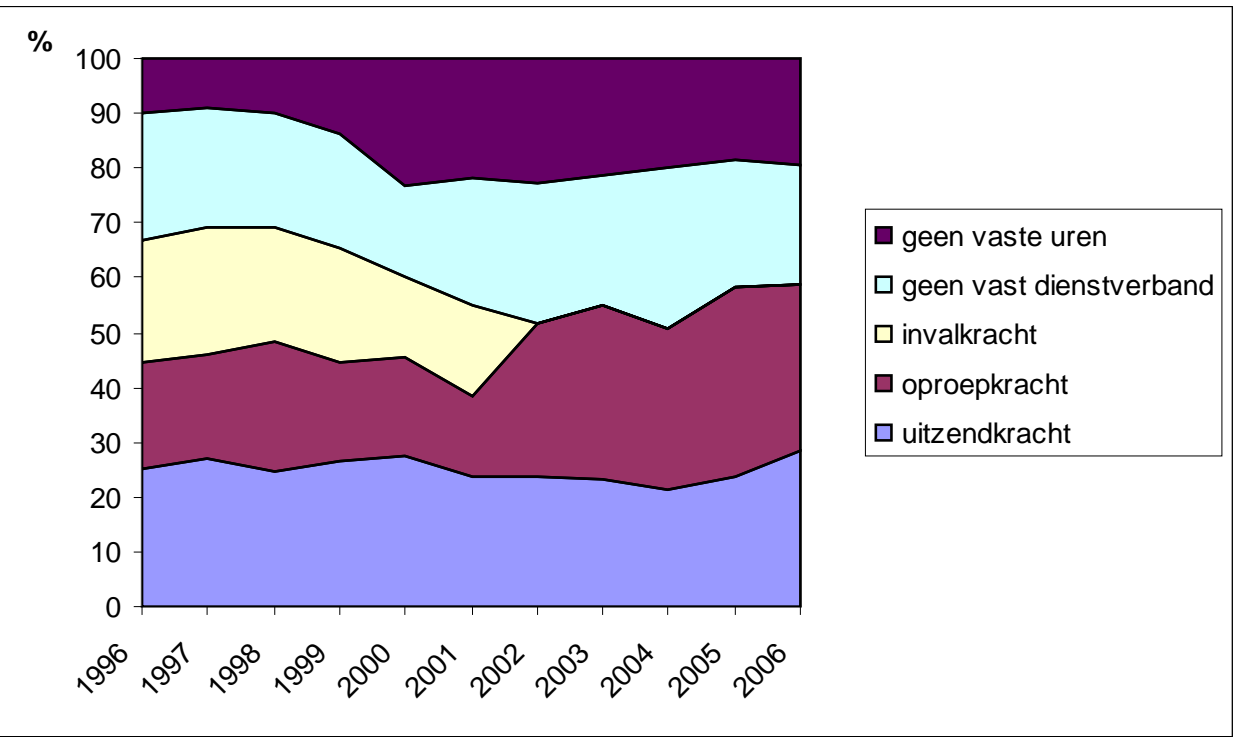

Bron: CBS (EBB)

Figuur II.6

Aandeel verschijningsvormen flexwerk in WO, 1996-2006

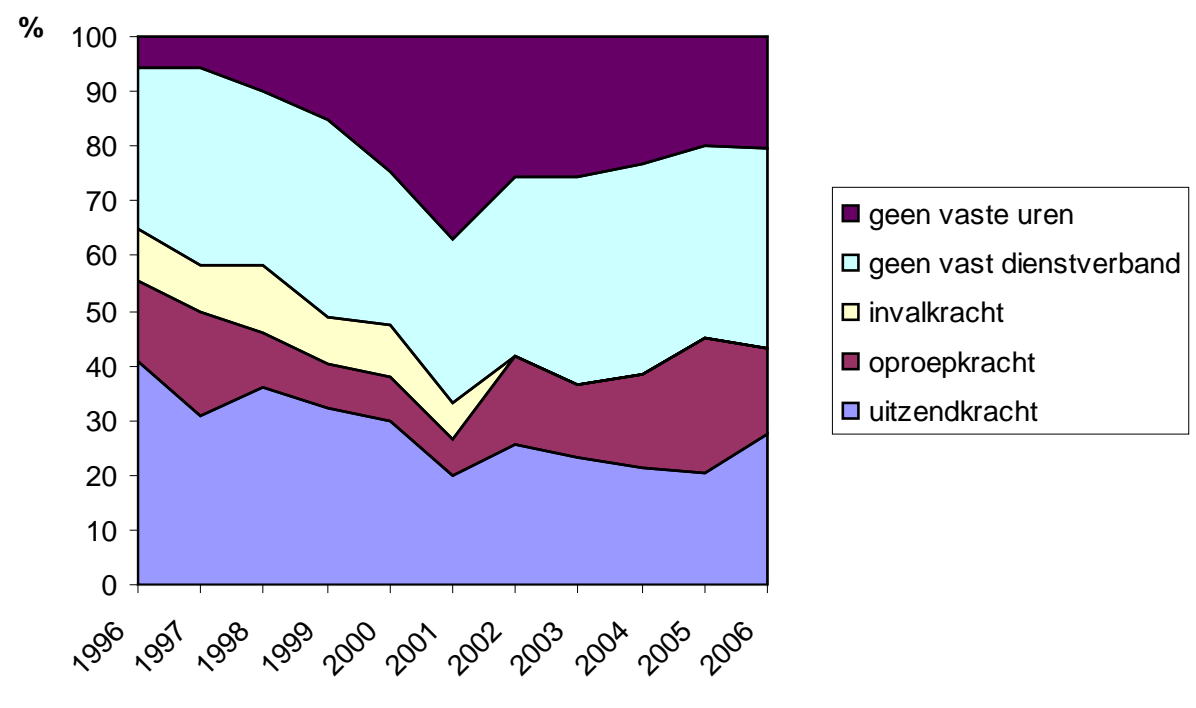

Bron: CBS (EBB) 


\section{Bijlage III Flexwerk per opleidingscategorie}

\section{Figuur III.1}

Aandeel verschijningsvormen flexwerk in VMBO theoretische leerweg, 1996-2006

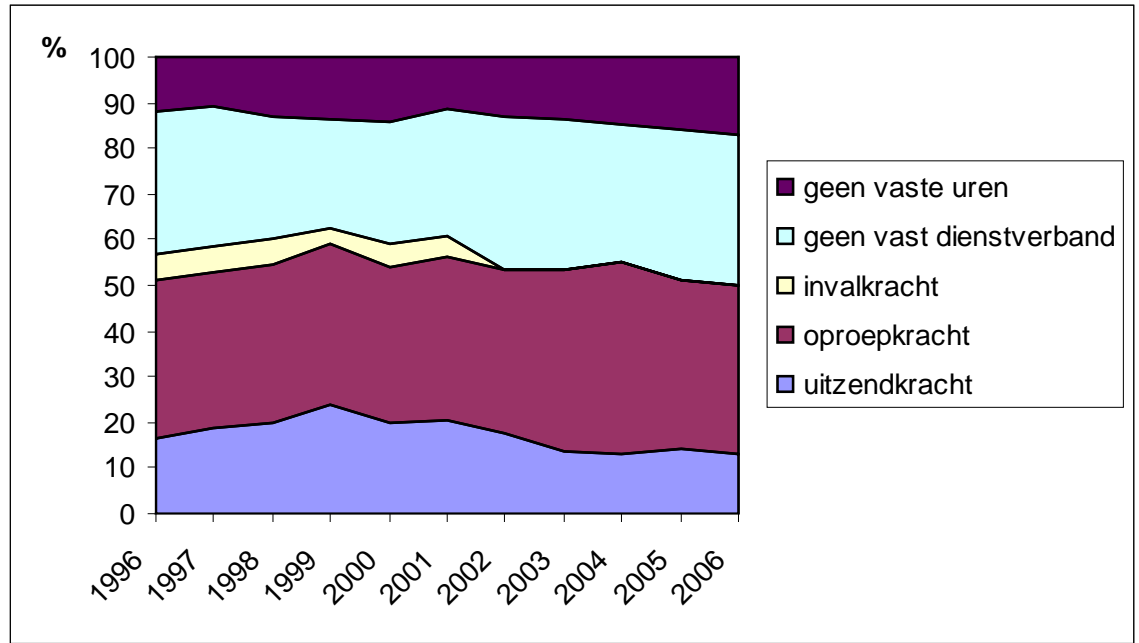

Bron: CBS (EBB)

Figuur III.2

Aandeel verschijningsvormen flexwerk in VMBO groen, 1996-2006

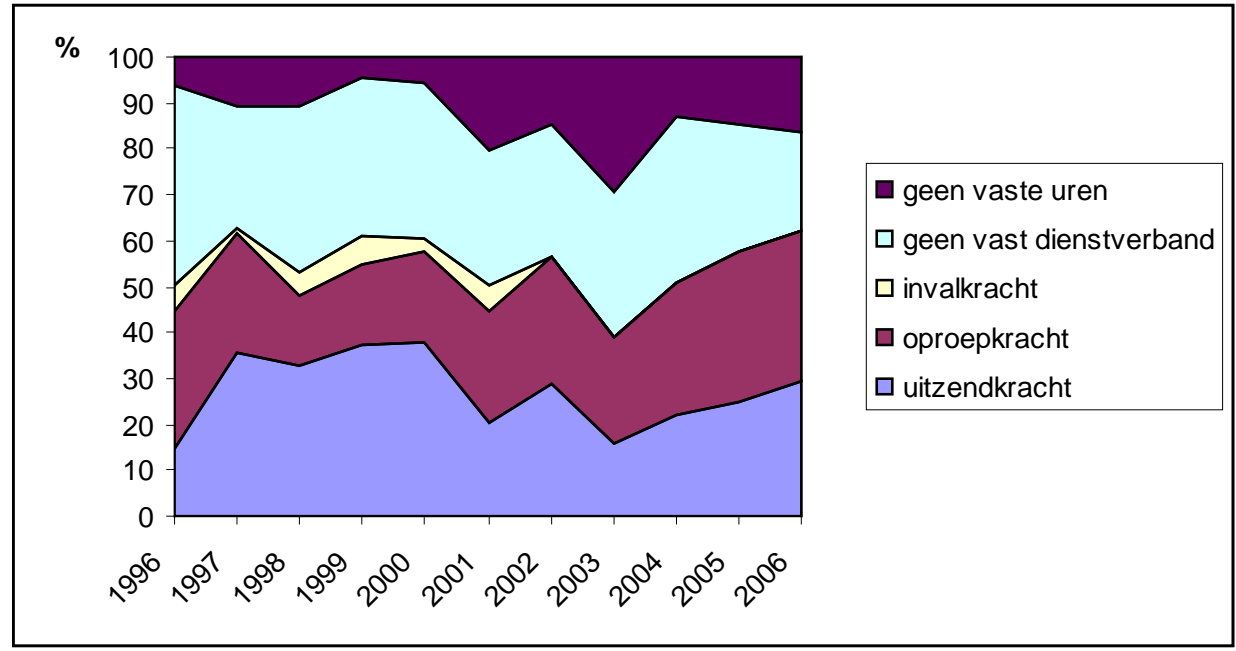

Bron: CBS (EBB) 
Figuur III.3

Aandeel verschijningsvormen flexwerk in VMBO techniek, 1996-2006

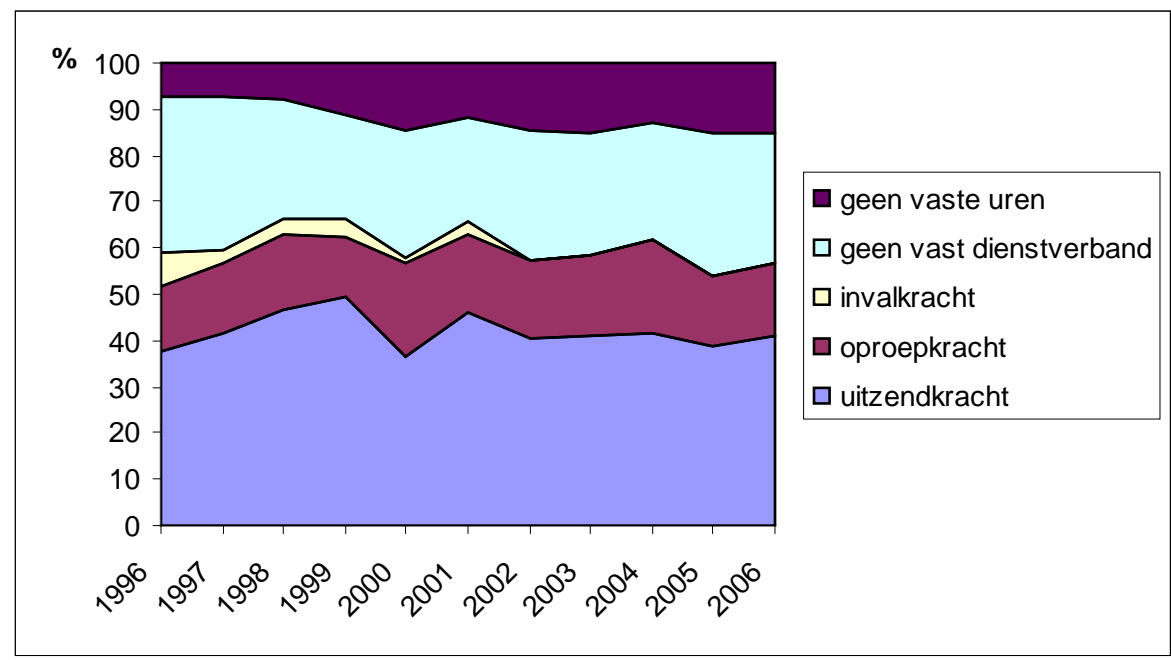

Bron: CBS (EBB)

Figuur III.4

Aandeel verschijningsvormen flexwerk in VMBO economie, 1996-2006

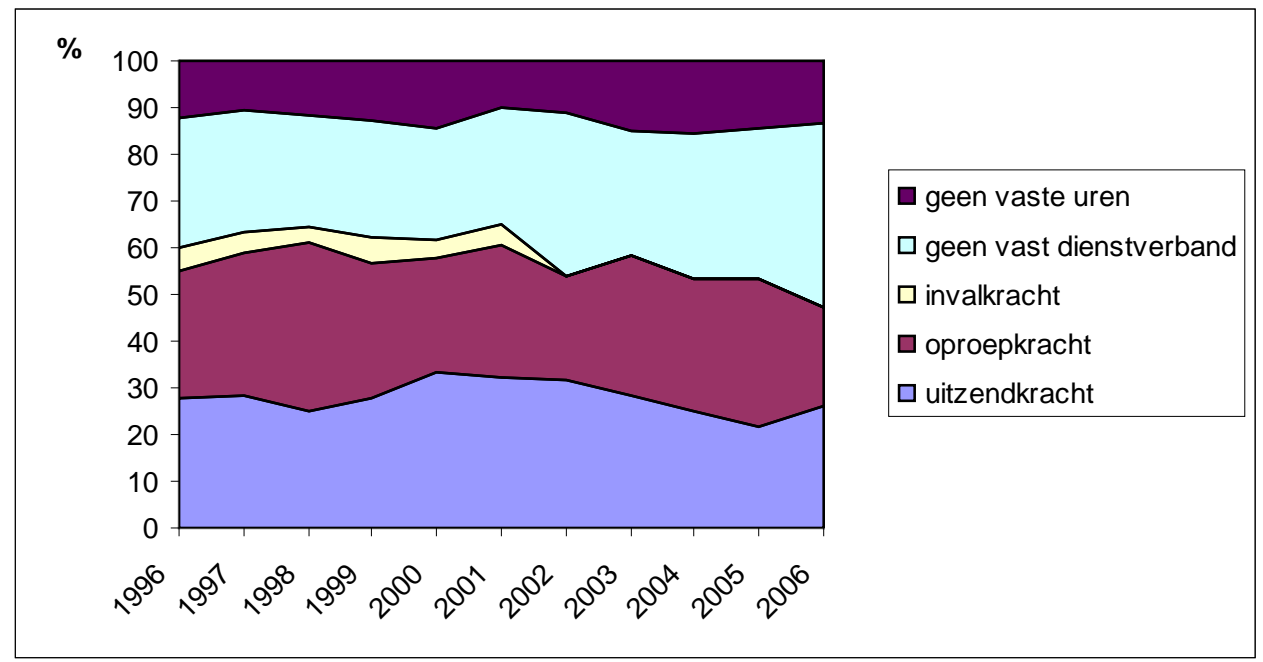

Bron: CBS (EBB) 
Figuur III.5

Aandeel verschijningsvormen flexwerk in VMBO verzorging, 1996-2006

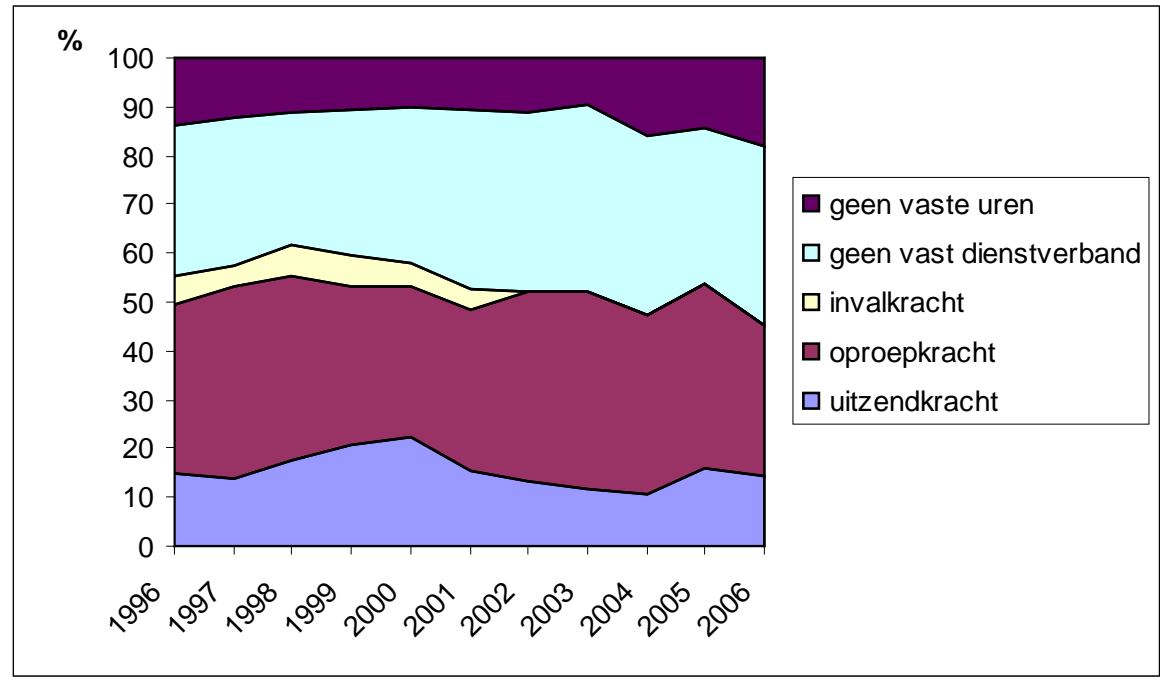

Bron: CBS (EBB)

Figuur III.6

Aandeel verschijningsvormen flexwerk in MBO groen, 1996-2006

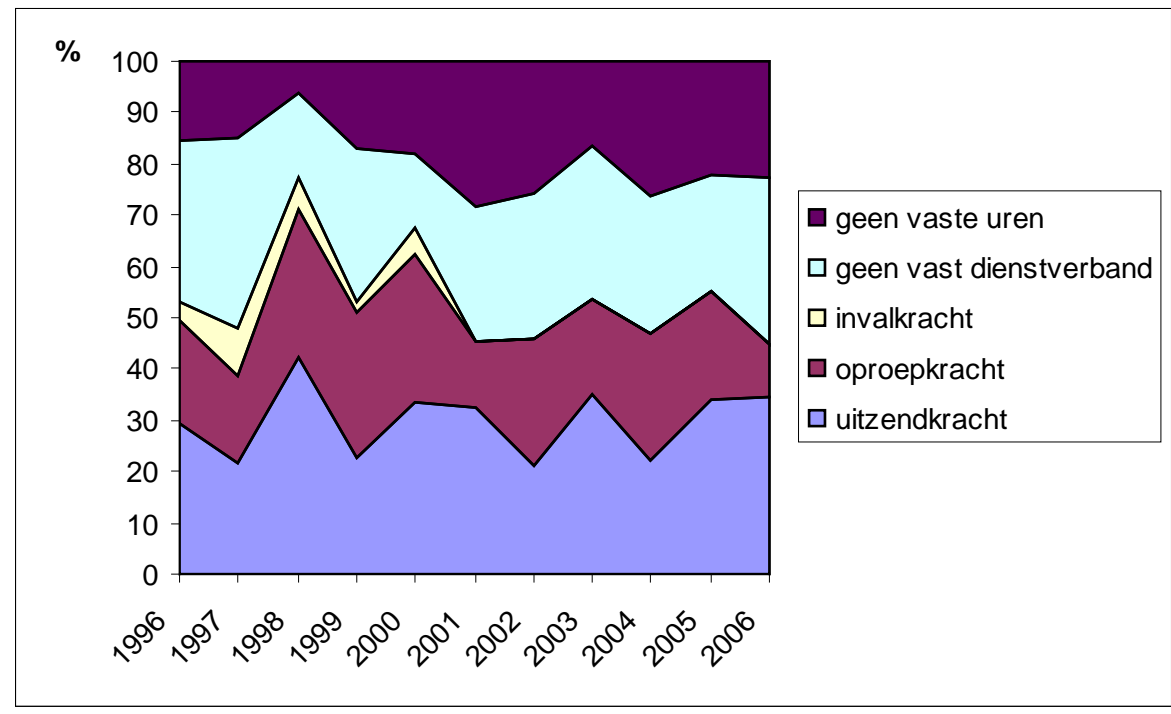

Bron: CBS (EBB) 
Figuur III.7

Aandeel verschijningsvormen flexwerk in MBO techniek, 1996-2006

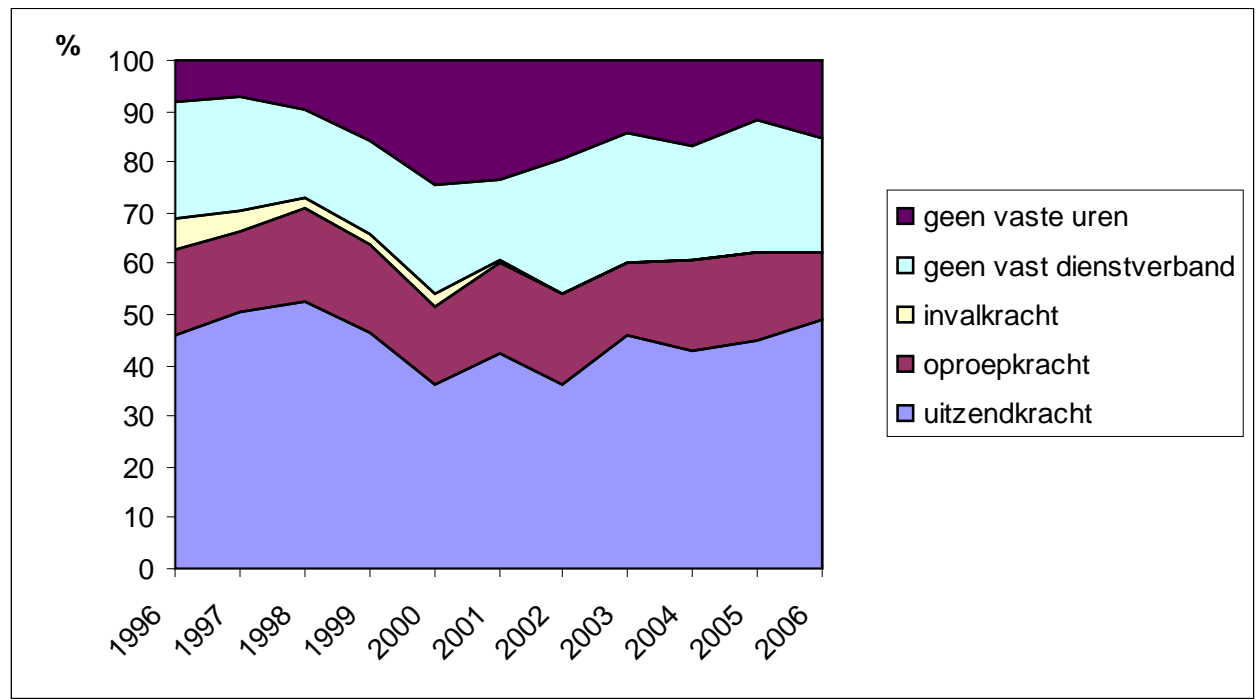

Bron: CBS (EBB)

\section{Figuur III.8}

Aandeel verschijningsvormen flexwerk in MBO sociaal-cultureel, 1996-2006

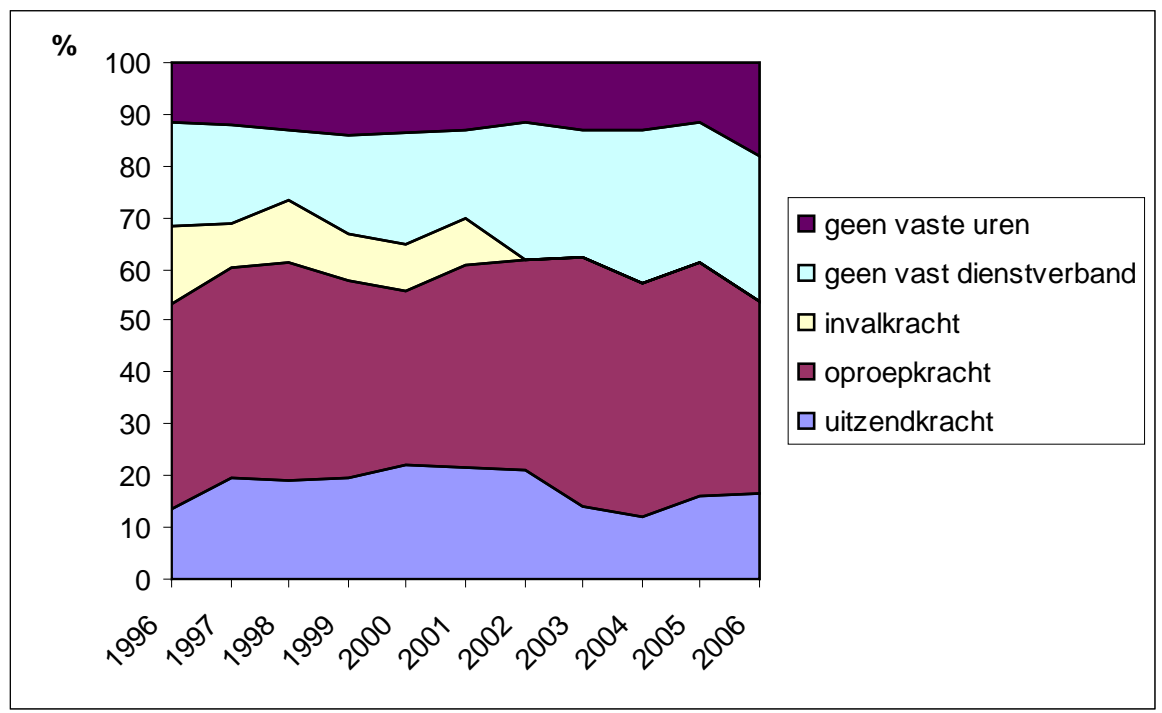

Bron: CBS (EBB) 
Figuur III.9

Aandeel verschijningsvormen flexwerk in MBO gezondheidszorg, 1996-2006

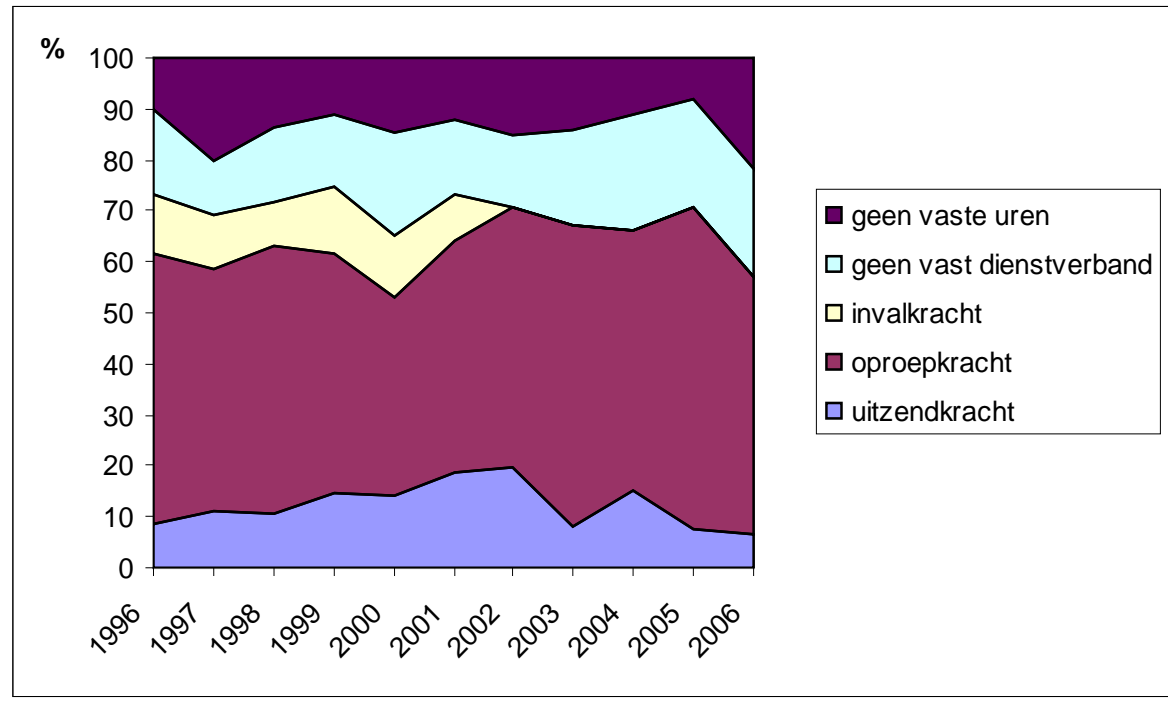

Bron: CBS (EBB)

Figuur III.10

Aandeel verschijningsvormen flexwerk in MBO economie, 1996-2006

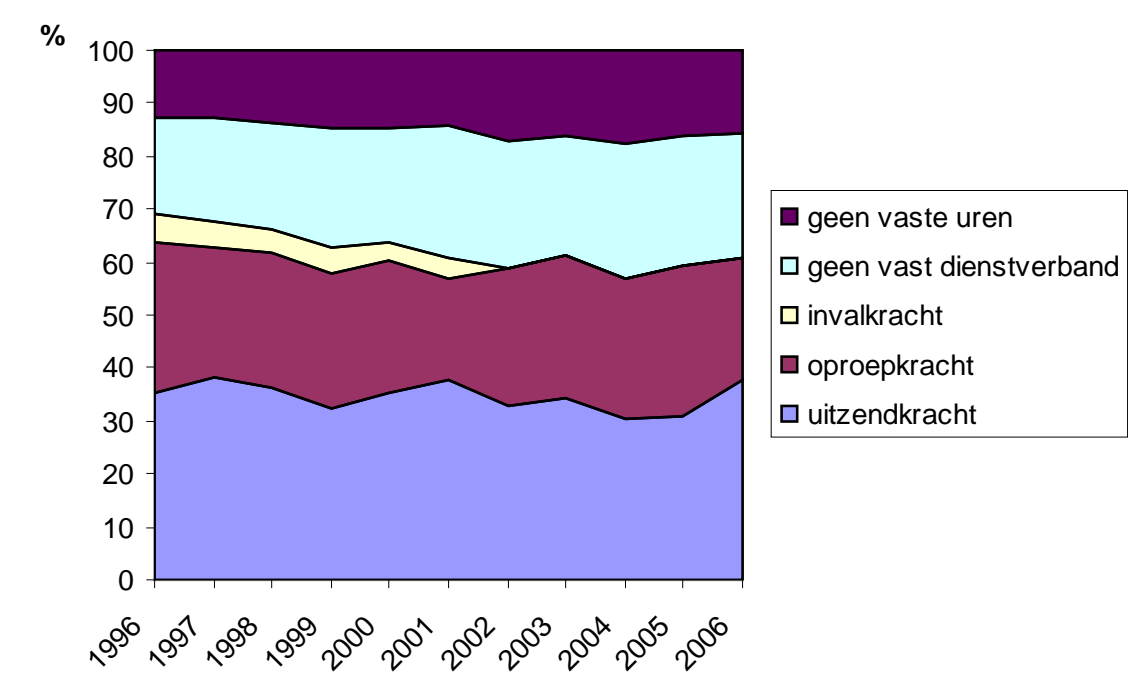

Bron: CBS (EBB) 
Figuur III.11

Aandeel verschijningsvormen flexwerk in HBO onderwijs, 1996-2006

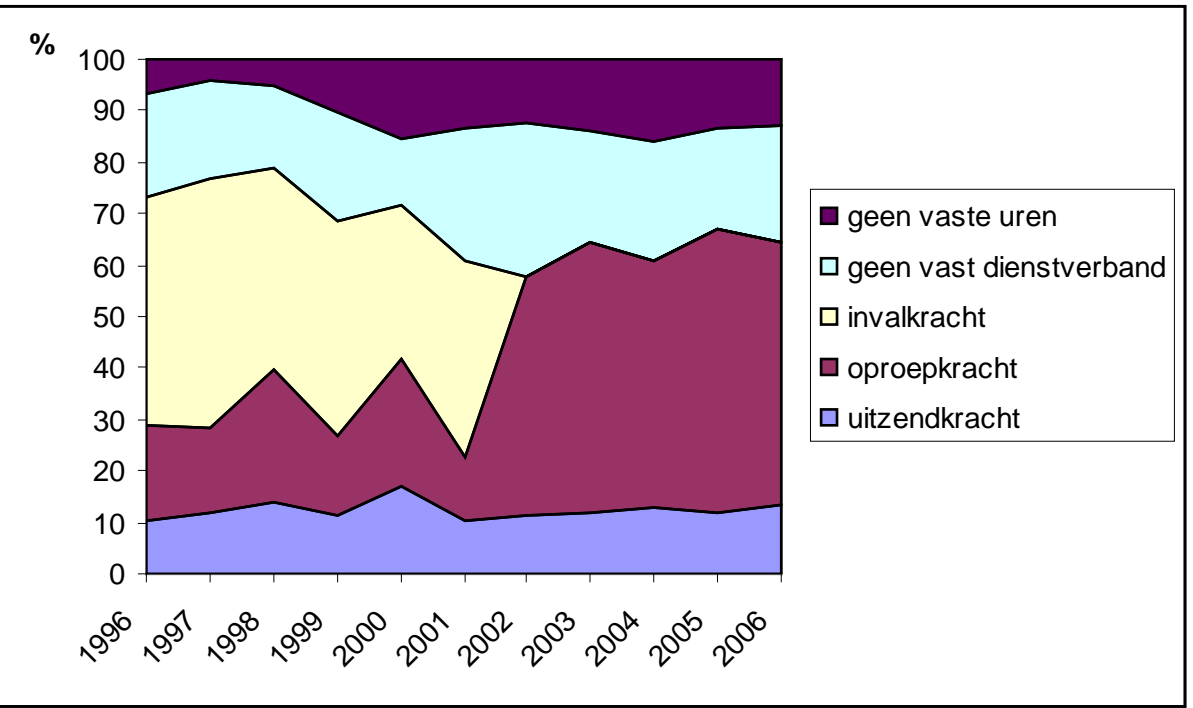

Bron: CBS (EBB)

Figuur III.12

Aandeel verschijningsvormen flexwerk in HBO sociaal-cultureel, 1996-2006

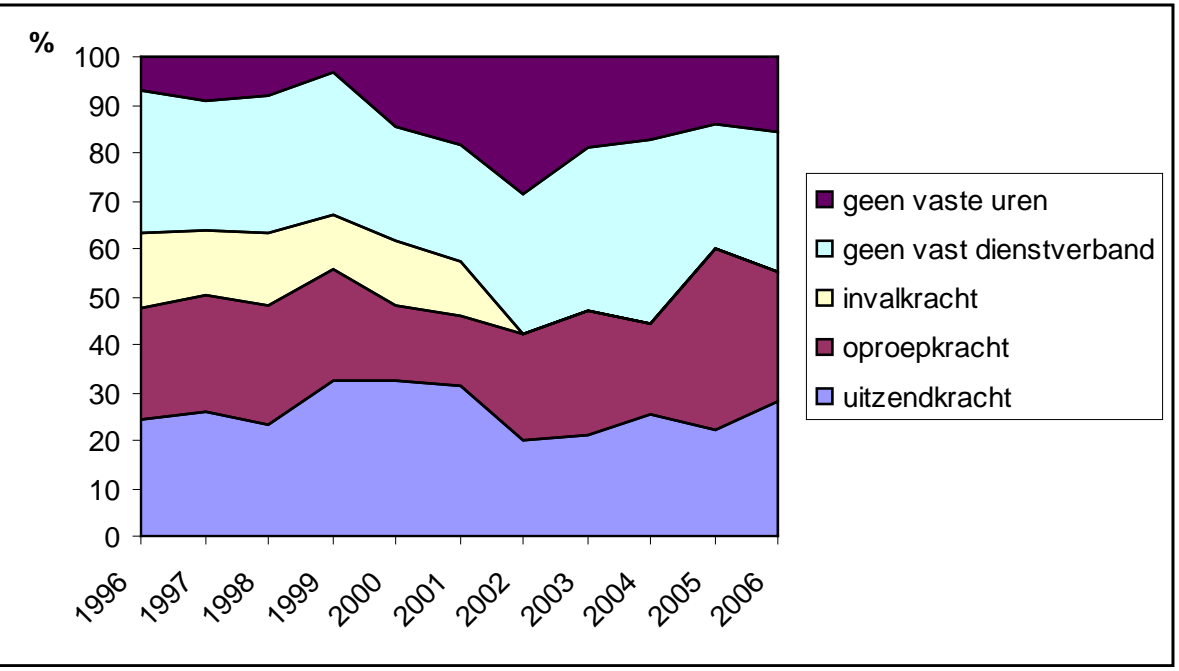

Bron: CBS (EBB) 
Figuur III.13

Aandeel verschijningsvormen flexwerk in HBO groen, 1996-2006

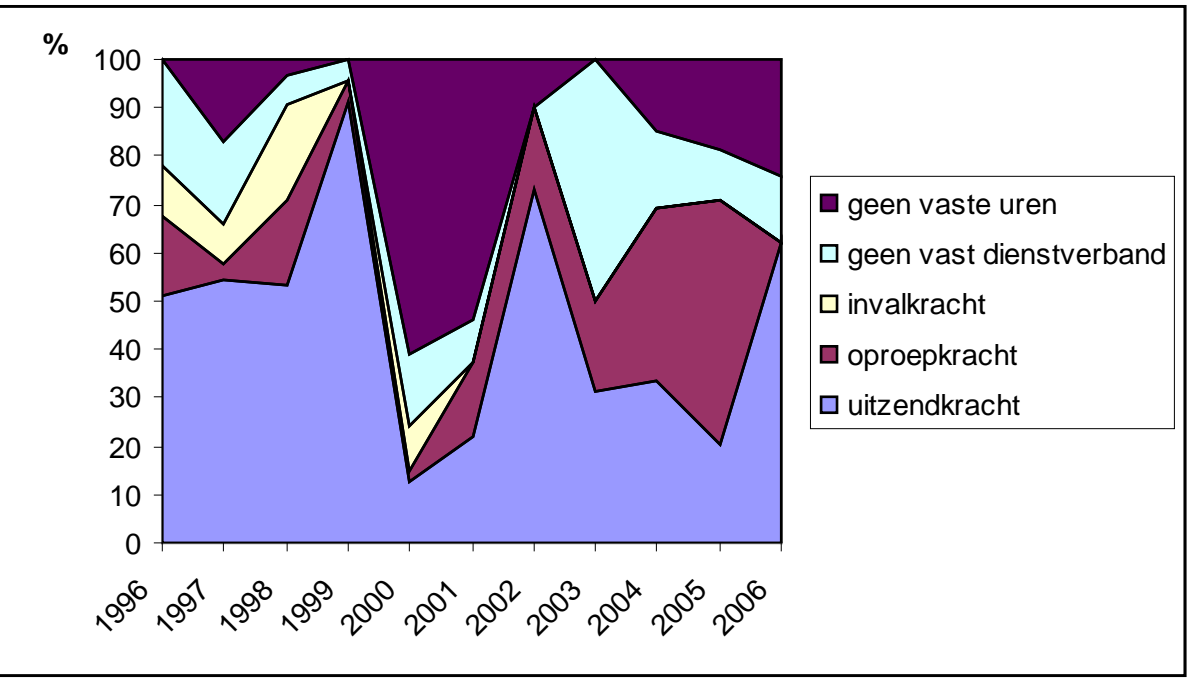

Bron: CBS (EBB)

Figuur III.14

Aandeel verschijningsvormen flexwerk in HBO techniek, 1996-2006

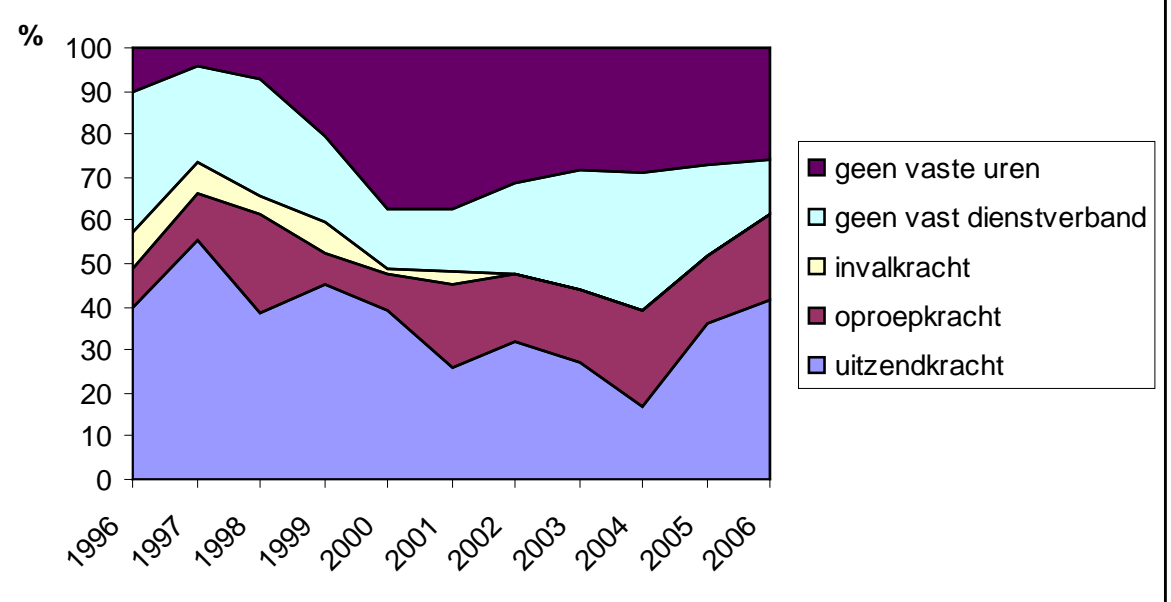

Bron: CBS (EBB) 
Figuur III.15

Aandeel verschijningsvormen flexwerk in HBO paramedisch, 1996-2006

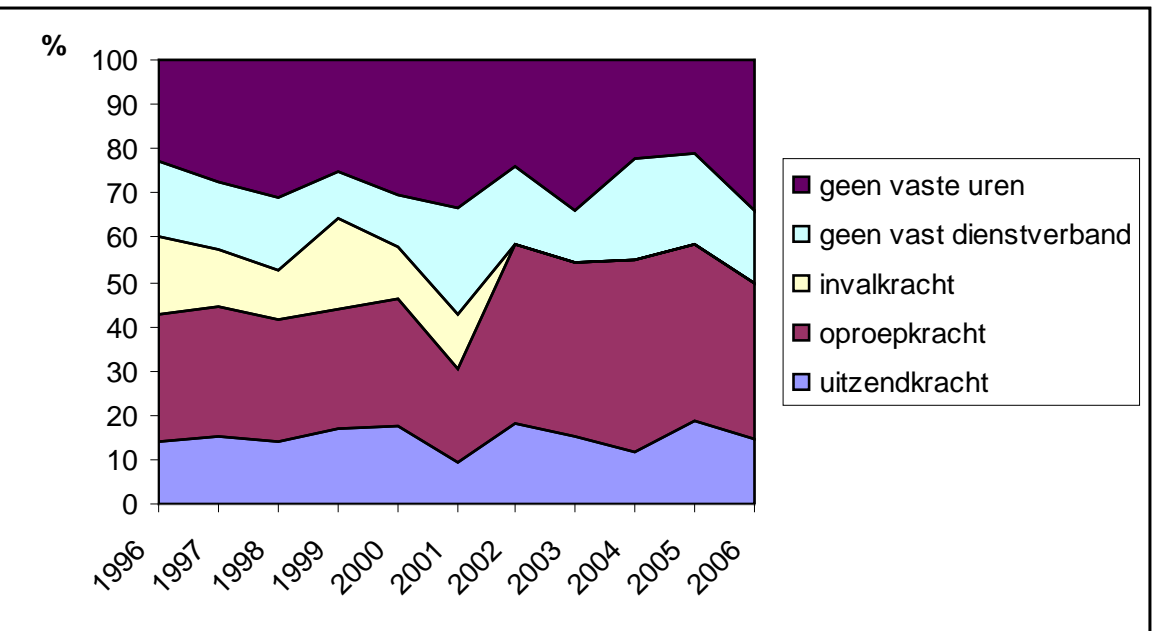

Bron: CBS (EBB)

\section{Figuur III.16}

Aandeel verschijningsvormen flexwerk in HBO economie, 1996-2006

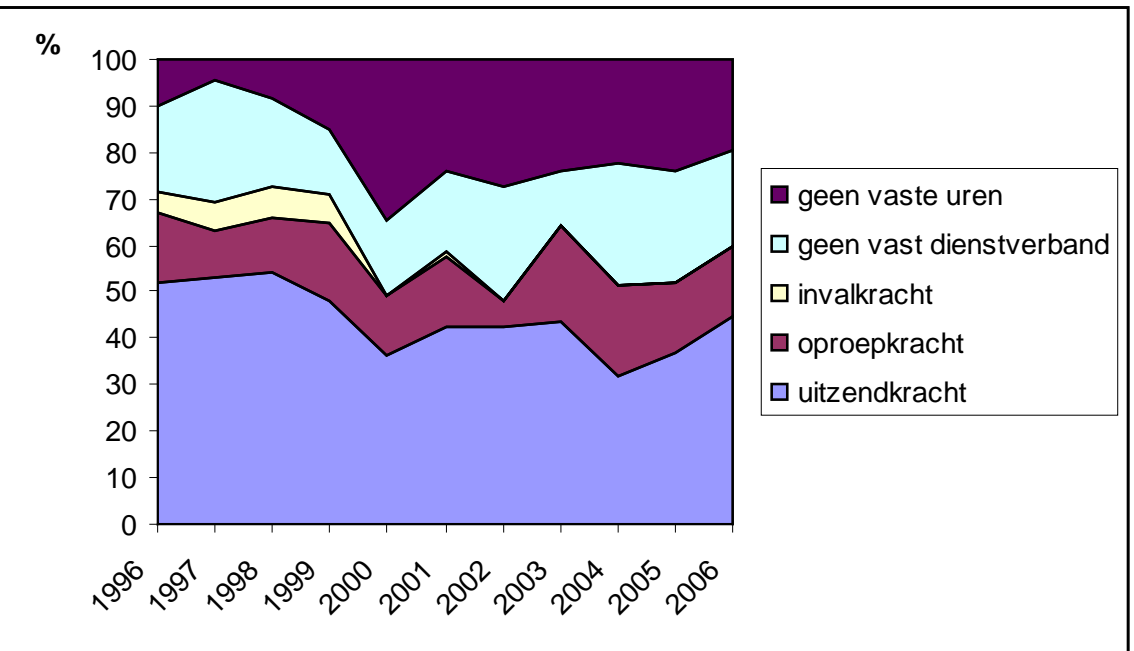

Bron: CBS (EBB) 
Figuur III.17

Aandeel verschijningsvormen flexwerk in WO letteren en sociaal-cultureel, 1996-2006

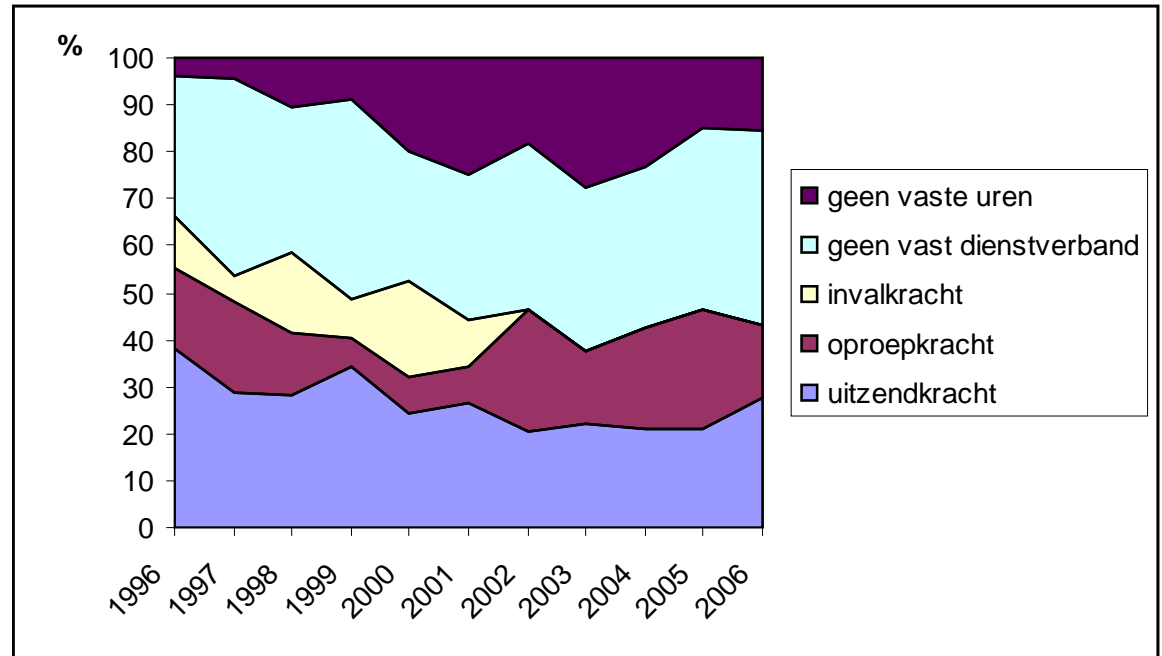

Bron: CBS (EBB)

Figuur III.18

Aandeel verschijningsvormen flexwerk in WO groen, 1996-2006

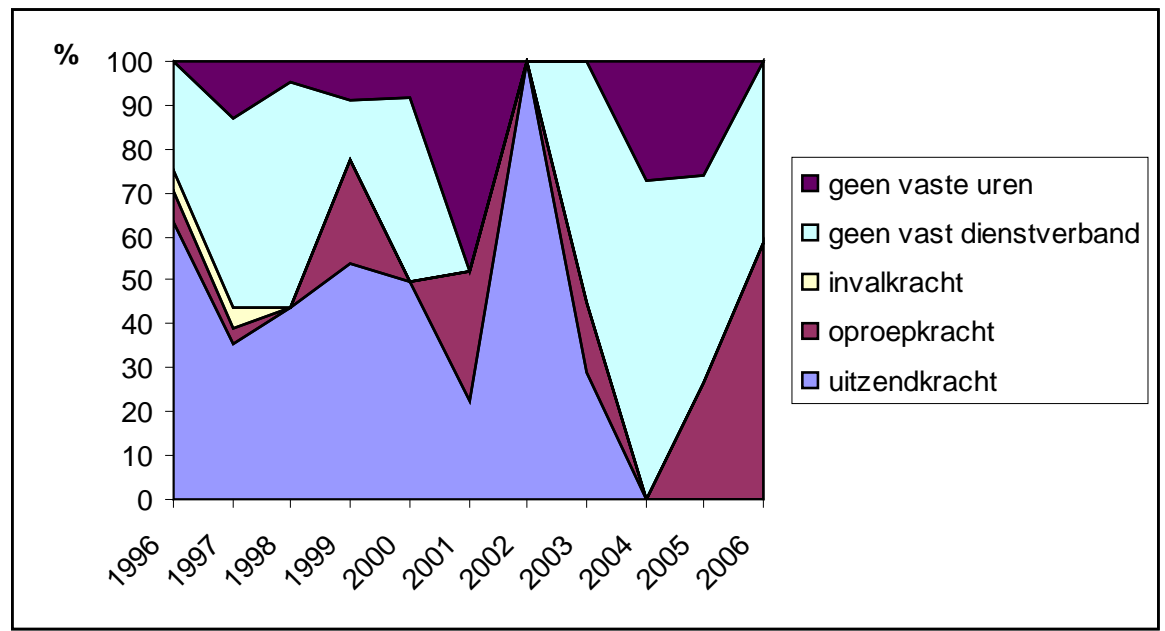

Bron: CBS (EBB) 
Figuur III.19

Aandeel verschijningsvormen flexwerk in WO techniek, 1996-2006

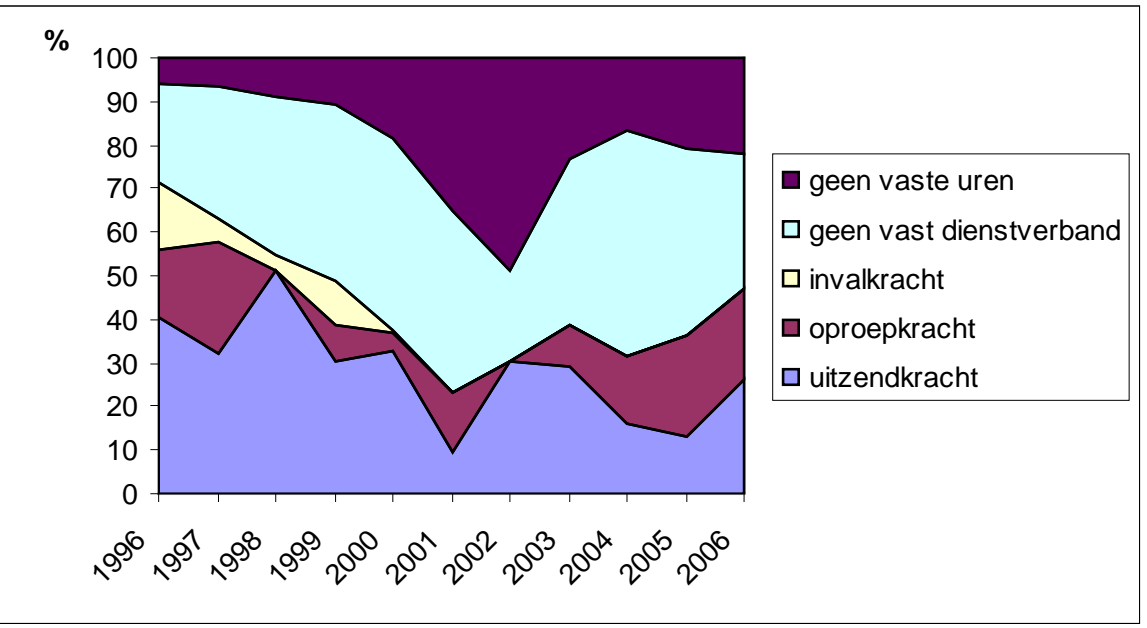

Bron: CBS (EBB)

Figuur III.20

Aandeel verschijningsvormen flexwerk in WO medisch, 1996-2006

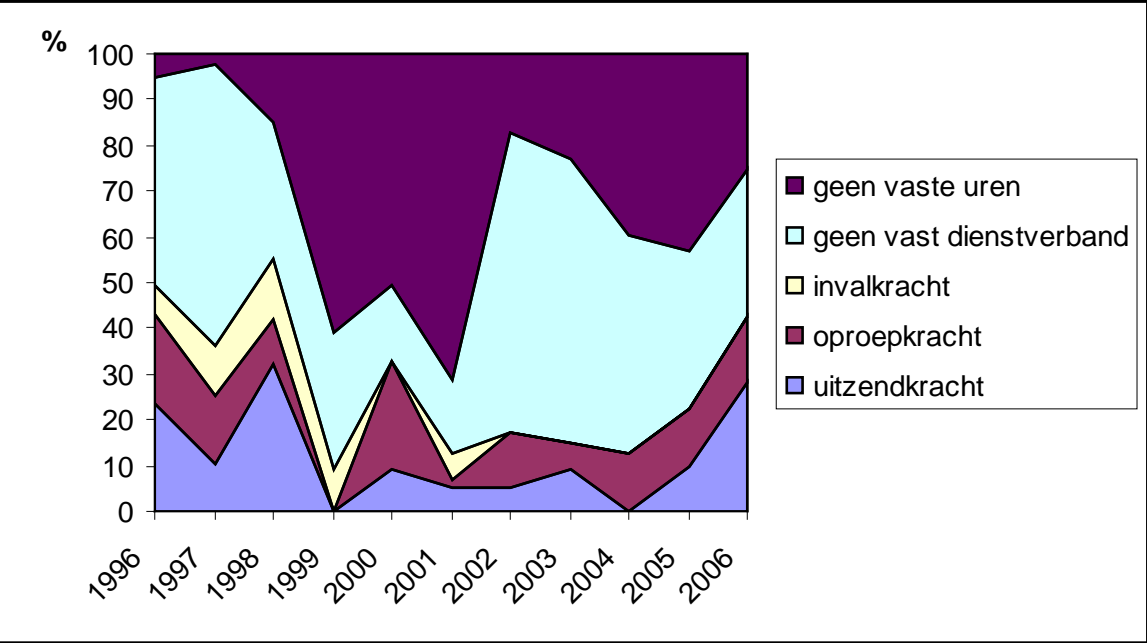

Bron: CBS (EBB) 
Figuur III.21

Aandeel verschijningsvormen flexwerk in WO economie, 1996-2006

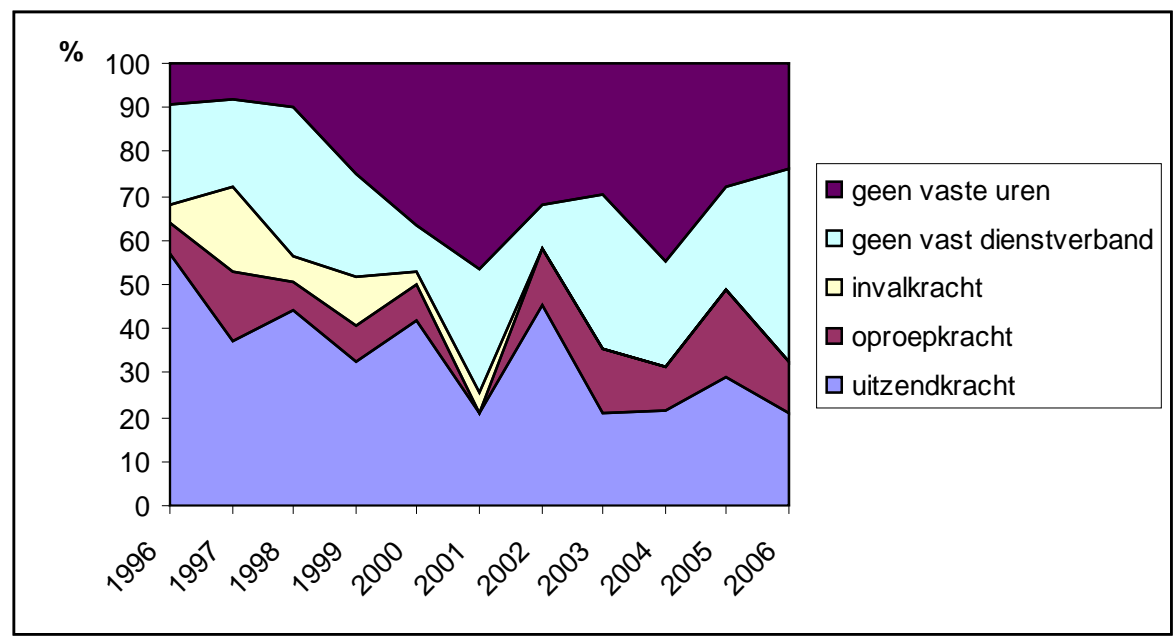

Bron: CBS (EBB) 